\title{
DIVISÃO DE CUSTOS E ALINHAMENTO ESTRATÉGICO DE UMA CADEIA DE SUPRIMENTOS INTEGRADA VERTICALMENTE: O CASO DO FRANGO BRASILEIRO
}

\author{
Paulo de Tarso Carletti filho
}

\begin{abstract}
Dissertação apresentada à Escola Superior de Agricultura "Luiz de Queiroz", Universidade de São Paulo, para obtenção do título de Mestre em Ciências. Área de Concentração: Economia Aplicada.
\end{abstract}

P I R A C I C A B A

Estado de São Paulo - Brasil

Maio - 2005 


\title{
DIVISÃO DE CUSTOS E ALINHAMENTO ESTRATÉGICO DE UMA CADEIA DE SUPRIMENTOS INTEGRADA VERTICALMENTE: O CASO DO FRANGO BRASILEIRO
}

\section{Paulo de Tarso Carletti Filho}

Engenheiro de Produção Mecânica

\section{Orientador: Prof. Dr. JOSÉ VICENTE CAIXETA FILHO}

\author{
Dissertação apresentada à Escola Superior \\ de Agricultura "Luiz de Queiroz", \\ Universidade de São Paulo, para obtenção \\ do título de Mestre em Ciências. Área de \\ Concentração: Economia Aplicada.
}

P I R A C I C A B A

Estado de São Paulo - Brasil

Maio - 2005 
Dados Internacionais de Catalogação na Publicação (CIP) DIVISÃO DE BIBLIOTECA E DOCUMENTAÇÃO - ESALQ/USP

Carletti Filho, Paulo de Tarso

Divisão de custos e alinhamento estratégico de uma cadeia de suprimentos

integrada verticalmente: o caso do frango brasileiro / Paulo de Tarso Carletti Filho. - Piracicaba, 2005.

156 p. : il.

Dissertação (mestrado) - - Escola Superior de Agricultura Luiz de Queiroz, 2005. Bibliografia.

1. Custo econômico 2. Frango 3. Indústria de alimento 4. Integração vertical 5. Logística 6. Planejamento estratégico 7. Produção em cadeia I. Título

CDD 338.4766493

"Permitida a cópia total ou parcial deste documento, desde que citada a fonte - O autor" 
DEDICO este trabalho a...

Deus por ter me dado as possibilidades

para desenvolver muitas tarefas.

A Paulo de Tarso Carletti, Vera Lucia Moraes Carletti

e Raquel de Luca Menezes, pelo apoio, amor e carinho,

OFEREÇO. 


\section{AGRADECIMENTOS}

Vou tentar ser breve, mas não economizarei linhas e comentários para agradecer àqueles que me ajudaram na realização deste trabalho e continuam contribuindo para a minha constante evolução pessoal e profissional.

Primeiramente agradeço ao meu pai, ícone de minhas caminhadas, líder, educador, exemplo de pessoa que constantemente me estimula com conselhos e ensinamentos a superar os obstáculos da vida. À minha mãe, presente em todos os momentos importantes e que com muito carinho sustenta os pilares do lar. Aos dois em conjunto, por terem sempre dado condições, acreditarem nos meus projetos e aceitarem fazer parte deles. Agradeço também a toda minha família, que fundamenta os verdadeiros valores religiosos católicos tradicionais.

Gostaria de fazer um especial agradecimento ao meu orientador professor Caixeta. Desde o dia em que entrei na ESALQ me deu todo o suporte e acreditou no desafio pessoal do projeto que vim desenvolver neste mestrado, com total apoio e compreensão. Com ele tive, ainda, o privilégio de desenvolver diversos trabalhos. Meus sinceros manifestos de admiração e respeito por este profissional que muito me ajudou e me ensinou, tanto no âmbito profissional quanto no acadêmico.

Um muito obrigado ao Carlos Bremer que desde o último ano da graduação, em São Carlos, sempre me abriu as portas do mercado de trabalho e do meio universitário, acreditou nesta idéia e esteve constantemente disposto a ajudar no que lhe estivesse ao alcance.

Um especial carinhoso obrigado à Raquel. Mesmo longe, tudo teria sido muito mais difícil se não estivesse ao meu lado, apoiando meus projetos pessoais e 
compartilhando dos riscos e turbulências dessas decisões com muita paciência, além do amor e do carinho dispensados a mim todos esses anos juntos.

Registro meus agradecimentos aos professores da ESALQ, em especial ao Pedro Marques, à Márcia Azanha e Ricardo Shirota Obrigado também ao professor Sílvio Pires, da UNIMEP, pela ajuda no final e por ter aceito o convite de participar da banca. O mesmo ao professor Marcos Neves, da FEARP, pelos ensinamentos e pelas contribuições.

Ao trio que me ajudou na realização do estudo de caso: Junior, grande amigo de faculdade sempre disponível aos meus chamados, me recebeu e coordenou os agendamentos para a realização do estudo de caso; Leopoldo Saboya, veterano colega de mestrado, um dos grandes responsáveis pelo sucesso da execução do estudo de caso, sempre disposto a ajudar e fornecer o que lhe era demandado para o desenvolvimento deste trabalho; Flávio Barreiros, do mesmo modo que o Leopoldo não mediu esforços para que este projeto chegasse ao seu fim. Especiais agradecimentos ao Rogério Lenza e ao Vicente Zuffo.

Registro o muito obrigado ao senhor José Carlos (APA), que gentilmente dispendeu parte de seu tempo para me receber numa entrevista particular sobre o projeto.

Não posso deixar de agradecer ao amigo Augusto Gameiro, otimista, empreendedor, líder e educador, me abriu diversas portas, além das longas conversas sobre o futuro profissional e os riscos de empreender. Um grande abraço para as "caixetetes" Lilian, Ana e Renata, minhas companheiras de orientador e no projeto Biomassa, e a todo o ESALQLog, grupo que já nasceu vencedor. Deixo o meu abraço aos amigos que construí no mestrado: Cassiano, Lu Gaúcha e Davi. Obrigado ao Jonas pela ajuda nas pesquisas sobre a cadeia de frango no Brasil. Não posso deixar de lembrar do Zé Ricardo, grande pessoa. A todos os demais colegas do curso e funcionários, em especial à Maielli, Helena, Ligiana e Pedro. 
Quero deixar meu sincero agradecimento à maestrina do Coral Luiz de Queiroz, Cinthia Pinotti. Como disse certa vez “...se todo lugar tivesse um coral, muitos dos problemas do mundo não existiriam...". A todo o coral que durante o primeiro ano do curso foi um dos alicerces que sustentaram este projeto. Um abraço especial ao professor Legal, por quem tenho uma grande admiração e considero exemplo de vida.

Outro à Rosalinda Chedian, coordenadora na Unaerp que me chamou para ministrar aulas. Foi uma grande satisfação poder fazer parte de sua equipe.

Aos sócios da Wert em Ribeirão Preto, pela dura labuta do nosso projeto.

Aos amigos Ricardo Nazareno e Edson Barbero pela amizade construída e pela ajuda durante a tomada de decisão de voltar para o meio acadêmico na busca de conhecimentos para conciliar tarefas com o meio empresarial.

À Dri Rota pelo seu excelente trabalho de ajustes e de correção.

À CAPES, pela bolsa concedida ao longo do ano de 2004.

Por fim, a todos que contribuíram de alguma forma para a realização deste trabalho e que não foram citados explicitamente. 


\section{SUMÁRIO}

Página

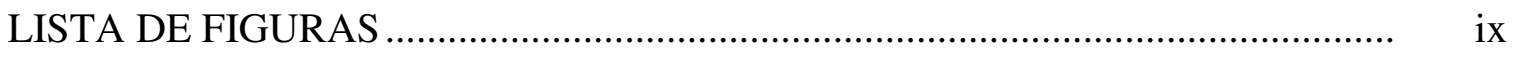

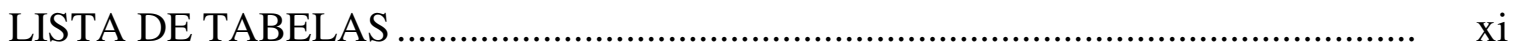

LISTA DE QUADROS .........................................................................

LISTA DE ABREVIATURAS E SIGLAS .................................................... xiii

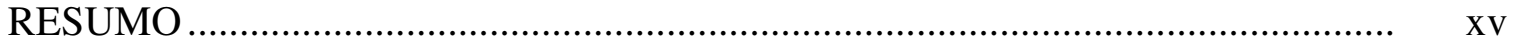

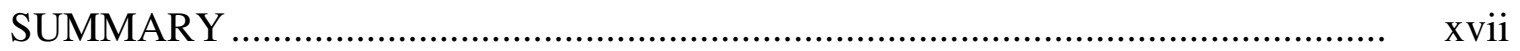

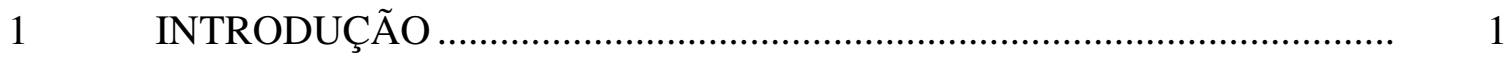

1.1 Justificativa da importância do trabalho ................................................ 1

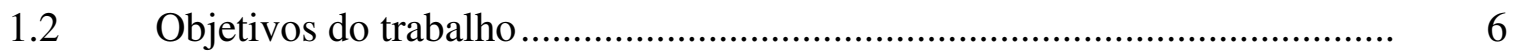

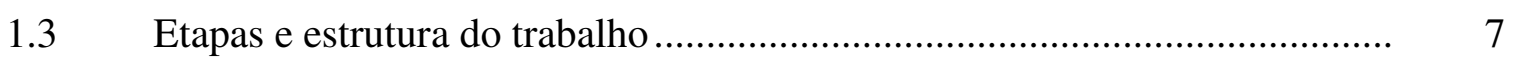

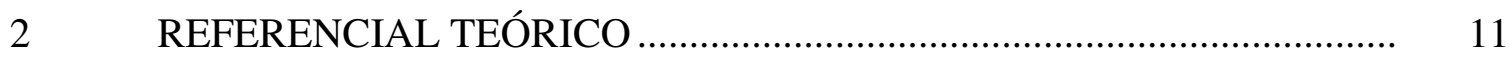

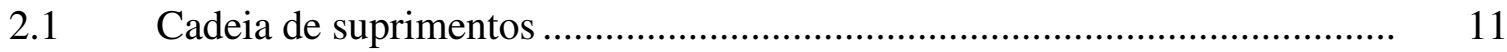

2.1.1 Evolução, definição e objetivos .......................................................... 11

2.1.2 Estratégia na cadeia de suprimentos ....................................................... 24

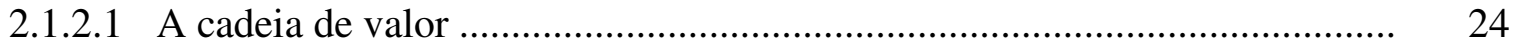

2.1.2.2 Análise do tipo de cadeia de suprimentos ................................................ 29

2.1.2.3 O alinhamento estratégico na cadeia de suprimentos ............................... 35

2.1.3 A cadeia de suprimentos no ambiente do agronegócio............................... 38

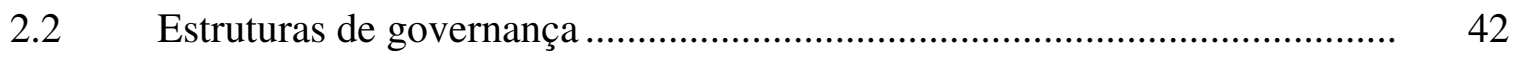

2.2.1 Economia dos custos de transação ............................................................ 44

2.2.2 A integração vertical ........................................................................ 50

3 A CADEIA DO FRANGO NO BRASIL ............................................ 62

3.1 A indústria de aves no Brasil ................................................................ 62 
3.2 A importância da carne de frango para o Brasil ...................................... 71

3.3 A gestão da cadeia de suprimentos de frango no Brasil ............................. 76

3.3.1 A cadeia produtiva de aves de corte .................................................. 76

3.3.2 A cadeia de suprimentos de aves de corte no sistema integrado .................. 78

3.3.3 Alinhamento estratégico na cadeia de suprimentos do frango..................... 81

4 METODOLOGIA PARA ANÁlisE DE CUSTOS NA CADEIA DE SUPRIMENTOS ....................................................................... 88

4.1 Modelo de Eficiência para canais de distribuição...................................... 88

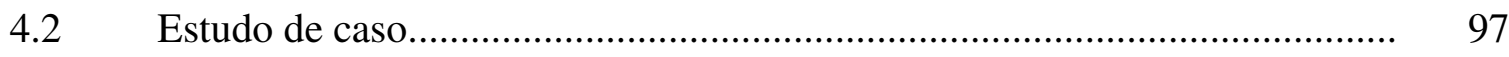

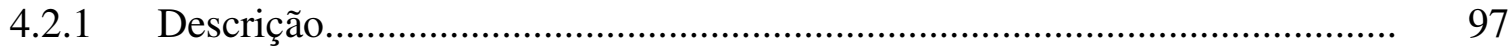

4.2.2 Metodologia Delphi e aplicação no caso da cadeia do frango..................... 98

4.2.3 Adaptação da cadeia do frango para realização do estudo de caso............... 100

4.2.4 A especificação dos dados e tabela........................................................... 104

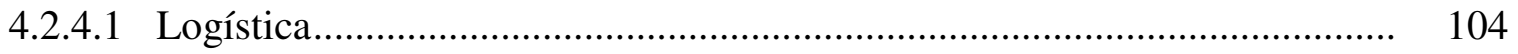

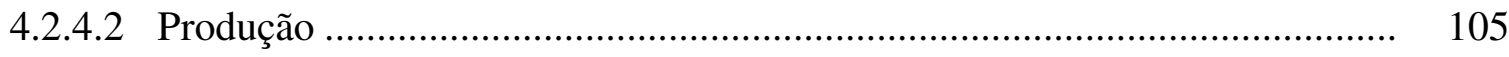

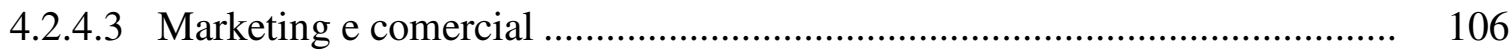

4.2.4.4 Finanças .................................................................................... 108

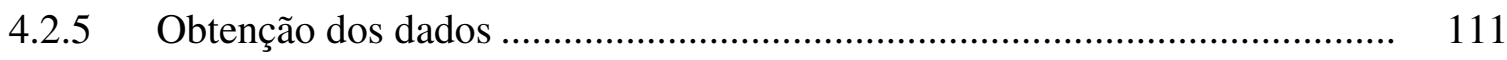

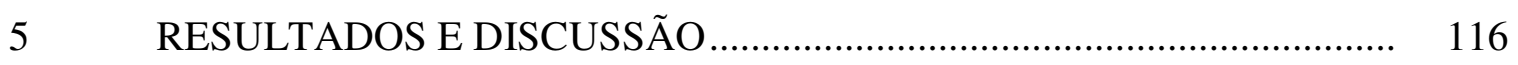

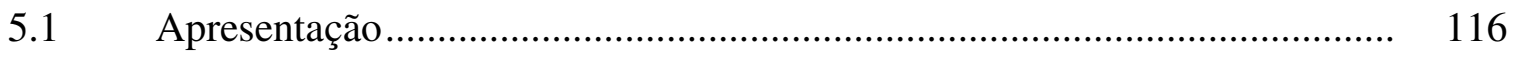

5.2 Análise dos resultados.................................................................. 120

5.3 Desenvolvimento de cenários .............................................................. 132

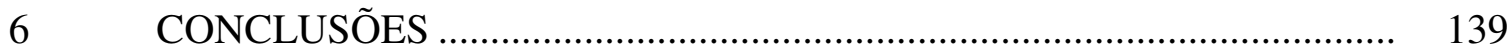

6.1 Limitações e recomendações de trabalhos futuros..................................... 147

REFERÊNCIAS BIBLIOGRÁFICAS .......................................................... 151 


\section{LISTA DE FIGURAS}

Página

1 Etapas seguidas para o desenvolvimento desta dissertação ............................ 8

2 Evolução do conceito de logística e suas implicações ....................................... 13

3 Elos primários principais de uma cadeia de suprimentos .............................. 16

4 Áreas empresariais departamentalizadas segregadas versus áreas empresariais funcionais integradas ........................................................................ 18

5 Gestão da cadeia de suprimentos e logística integrada ................................... 20

6 A cadeia de valor em uma organização ..................................................... 25

7 Zona de alinhamento estratégico e mudanças na estratégia da cadeia de suprimentos durante a evolução do ciclo de vida do produto ........................... 37

8 Enfoque de sistemas de agronegócios........................................................ 38

9 O ambiente do agronegócio ..................................................................... 40

10 Esquema de indução das formas de governança ............................................. 46

11 Estruturas de governança na cadeia de suprimentos..................................... 49

12 Comprar ou produzir: uma análise simplificada do grau de integração ............. 54

13 O escopo da empresa: especialização versus integração ................................. 55

14 Exportações brasileiras de carne de frango por segmento, em volume ............. 70

15 Cadeia produtiva de aves de corte........................................................... 78

16 Cadeia de suprimentos do frango.............................................................. 80

17 Posicionamento da cadeia do frango na zona de alinhamento estratégico ......... 87

18 Fluxos de marketing em canais de distribuição ........................................... 90

19 Agrupamento de elos da cadeia de suprimentos do frango............................. 101

20 Passos seguidos no desenvolvimento do estudo de caso .............................. 112

21 Participação de cada elo nos custos da cadeia do frango ................................ 122 
22 Divisão dos custos entre as áreas da cadeia do frango....................................... 126

23 Porcentagem de agregação de custos dos fluxos da cadeia de suprimentos ........ 127 


\section{LISTA DE TABELAS}

Página

1 Exportação brasileira de carnes em 2003, incluindo carnes industrializadas ..... 72

2 Produção mundial de carne de frango, em milhares de toneladas ..................... 73

3 Produção brasileira de carne de frangos (em toneladas) e mercados consumidores ................................................................................... 74

4 Destino e porcentagem das exportações brasileiras de frango de corte e inteiro 75

5 Distribuição por região brasileira de alojamento de matrizes, produção de pintos para corte e abate de frango com SIF em 2003 ................................. 76

6 O modelo de eficiência e fluxos de marketing............................................... 92

7 As divisões matriciais no quadro do modelo de eficiência ............................... 93

8 Modelo de eficiência adaptado para cadeia de suprimentos do frango integrada verticalmente. .................................................................... 110

9 Resultados do estudo de caso .................................................................. 116

10 Comparação dos resultados estatísticos das duas análises para os fluxos .......... 127

11 Cenário 1: rearranjo do fluxo de propriedade na cadeia de suprimentos........... 133

12 Cenário 2: ponderação dos custos pelo potencial de agregação de valor dos

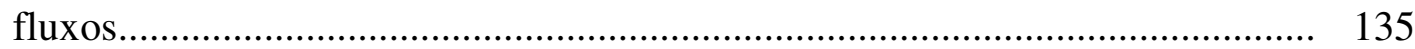

13 Cenário 3: potencial de agregação de valor baixo para os fluxos de produção.. 136

14 Comparativo da participação normativa na agregação de valor para os três cenários 


\section{LISTA DE QUADROS}

\begin{tabular}{|c|c|}
\hline \multirow{2}{*}{\multicolumn{2}{|c|}{$\begin{array}{r}\text { Págin } \\
. \quad 14\end{array}$}} \\
\hline & \\
\hline 2 & Aspectos comparativos entre produto funcional e produto inovador ................. \\
\hline & Aspectos gerenciais da cadeia eficiente versus cadeia responsiva ... \\
\hline & A decisão de governança das transações... \\
\hline & Compilação dos fatores a considerar com foco nas vantagens e desvantagens \\
\hline
\end{tabular}




\section{LISTA DE ABREVIATURAS E SIGLAS}

$\begin{array}{ll}\text { ABC } & \text { Activity Based Costing } \\ \text { ABEF } & \text { Associação Brasileira dos Produtores e Exportadores de Frango } \\ \text { APA } & \text { Associação Paulista de Avicultura } \\ \text { APICS } & \text { American Production and Inventory Control Society } \\ \text { APINCO } & \text { Associação dos Produtores de Pinto para Corte } \\ \text { ASLOG } & \text { Associação Brasileira de Logística } \\ \text { BNDES } & \text { Banco Nacional de Desenvolvimento Econômico e Social } \\ \text { CD } & \text { Centro de Distribuição } \\ \text { CEO } & \text { Chief Executive Officer } \\ \text { CMV } & \text { Custo da Mercadoria Vendida } \\ \text { CPFR } & \text { Collaborative Planning, Forecasting and Replenishment } \\ \text { CPV } & \text { Custo do Produto Vendido } \\ \text { CS } & \text { Cadeia de Suprimentos } \\ \text { CSA } & \text { Commodity Systems Approach } \\ \text { ECR } & \text { Efficient Consumer Response } \\ \text { ECT } & \text { Economia dos Custos de Transação } \\ \text { EESC } & \text { Escola de Engenharia de São Carlos } \\ \text { EMBRAPA } & \text { Empresa Brasileira de Pesquisa Agropecuária } \\ \text { ESALQ } & \text { Escola Superior de Agricultura "Luiz de Queiroz" } \\ \text { EUA } & \text { Estados Unidos da América } \\ \text { FEA } & \text { Faculdade de Economia, Administração de Contabilidade } \\ \text { FIESP } & \text { Federação das Indústrias do Estado de São Paulo } \\ \text { GCS } & \text { Gestão da Cadeia de Suprimentos }\end{array}$




$\begin{array}{ll}\text { IEA } & \text { Instituto de Economia Aplicada } \\ \text { JIT } & \text { Just-in-Time } \\ \text { JIT II } & \text { Just-in-Time II } \\ \text { NEI } & \text { Nova Economia Institucional } \\ \text { PIB } & \text { Produto Interno Bruto } \\ \text { PRC } & \text { Popular Republic of China } \\ \text { QR } & \text { Quick Response } \\ \text { RH } & \text { Recursos Humanos } \\ \text { SAG } & \text { Sistema do Agronegócio } \\ \text { SCOR } & \text { Supply Chain Operations Reference Model } \\ \text { SCM } & \text { Supply Chain Management } \\ \text { SIF } & \text { Sistema de Inspeção Federal } \\ \text { TI } & \text { Tecnologia de Informação } \\ \text { UBA } & \text { União Brasileira de Avicultura } \\ \text { UNICAMP } & \text { Universidade Estadual de Campinas } \\ \text { USA } & \text { United States of America } \\ \text { USDA } & \text { United States Department of Agriculture } \\ \text { USP } & \text { Universidade de São Paulo }\end{array}$




\title{
DIVISÃO DE CUSTOS E ALINHAMENTO ESTRATÉGICO DE UMA CADEIA DE SUPRIMENTOS INTEGRADA VERTICALMENTE: O CASO DO FRANGO BRASILEIRO
}

\author{
Autor: PAULO DE TARSO CARLETTI FILHO \\ Orientador: Prof. JOSÉ VICENTE CAIXETA FILHO
}

\section{RESUMO}

A proposta do presente estudo é contribuir na discussão sobre gestão da cadeia de suprimentos em ambientes integrados verticalmente. Diante deste cenário, foi sugerida a investigação da cadeia do frango brasileira para análise das vantagens, das desvantagens, dos fatores a considerar na integração vertical e na indicação de um alinhamento estratégico entre os elos. Para tanto, foi realizado um estudo de caso explanatório cujo método propõe adaptar um modelo de análise de canais de distribuição para o caso de uma cadeia de suprimentos integrada verticalmente com foco em custos. Detectou-se que a sinergia existente entre os elos de uma cadeia integrada facilita o desenvolvimento de trabalhos conjuntos na cadeia de valor, assim como a visão integrada da divisão de custos. O principal elo da cadeia do frango é o fabricante, pois além de ser o que mais agrega custo (em torno de $51 \%$ ) é o gestor e centralizador que toma quase todas as decisões estratégicas. Este fato contribui expressivamente para que também acumule diversos custos da cadeia, dificilmente mensuráveis, como os custos de transação. Os resultados obtidos e as análises realizadas permitem concluir que a cadeia do frango pode ser gerenciada segundo uma estratégia híbrida: a da eficiência das 
operações entre os elos à jusante do fabricante e a da agilidade à montante do mesmo, oferecendo ganhos de custo e de aumento do nível de serviço. 


\title{
COSTS DIVISION AND STRATEGIC ALIGNMENT OF A VERTICAL INTEGRATED SUPPLY CHAIN: THE BRAZILIAN POULTRY CASE
}

\author{
Author: PAULO DE TARSO CARLETTI FILHO \\ Adviser: Prof. JOSÉ VICENTE CAIXETA FILHO
}

\section{SUMMARY}

The purpose of this work is to contribute to the discussion about supply chain management concepts for vertical integrated environments. The investigation of the Brazilian poultry chain was proposed in order to analyze the advantages, the disadvantages, the factors to be considered in the vertical integration and the indication of a supply chain strategy alignment. An explanatory case study was conducted. The method suggests to adapt a distribution chain model to a vertical integrated supply chain model, focusing on costs. It was detected that the synergy between the players of an integrated chain contributes to the development of common issues in the value chain and in the integrated cost division. The producer is the main player of the poultry chain, with approximately $51 \%$ of the total costs and is the centralizer of almost all strategic decisions. This fact contributes for the accumulating of some cost of this chain to its structure, hardly measurable, like the transaction costs. The results obtained and the analysis done allow concluding that this chain can be managed within a hybrid strategy: the efficiency of the operations in the downstream players from the producer and the agility upstream from it, offering gains from costs and high service level simultaneously. 


\section{INTRODUÇÃO}

\subsection{Justificativa da importância do trabalho}

Diversos estudos que descrevem a competição no meio empresarial têm documentado que as empresas tentam desenhar estratégias focadas em sobrevivência, crescimento e lucro.

O cenário de atuação e o contexto das empresas estão relacionados a ambientes extremamente dinâmicos, buscando a necessidade de constantes mudanças e adaptações. A velocidade com que elas avançam é tal que muitas organizações perceberam a necessidade de reavaliarem técnicas e modelos vencedores no passado que não se mostram mais sustentáveis no presente.

Percebe-se que muitas empresas trabalham tradicionalmente voltadas para a otimização de processos visando principalmente à questão de custos e de lucros, com focos isolados em seus ambientes de atuação. Desta maneira, não dão importância aos possíveis impactos de seus resultados em fornecedores e clientes.

Tal visão não-sistêmica das organizações integradas resgata um contexto de competição indireta dentro da cadeia criada por essas empresas, em detrimento de uma necessidade maior de trabalhos conjuntos entre as mesmas.

Por outro lado, existem as que já perceberam a necessidade de formulação de estratégias e atividades de colaboração e de cooperação entre elos à jusante (no sentido para trás) e à montante (no sentido para frente) de sua atuação como questão de sobrevivência, passando de adversários isolados para uma equipe de colaboradores dependentes entre si. 
O beneficio gerado por um elo da cadeia pode se refletir para os demais elos e vice-versa, desde que o alinhamento estratégico esteja acordado entre todos e as atividades sejam desenvolvidas para os objetivos comuns de todas as organizações atuantes.

Vários autores afirmam que a competição passou do meio empresarial para unidades virtuais de negócios, as também chamadas cadeias ou redes de empresas. Virtuais porque não existem fisicamente, mas funcionam implicitamente nos contratos ou acordos comerciais de parcerias, de cooperações ou até de colaboração.

Desse modo, Pires (2004, p.106) acrescenta que o atual desenvolvimento das cadeias virtuais está na busca dos benefícios da tradicional integração vertical (uma empresa sendo a proprietária de diversos elos de uma cadeia) sem haver o ônus pela propriedade de todos os ativos produtivos ao longo dessa cadeia.

O desafio está em visualizar e analisar as estratégias de gestão por parcerias desse tipo de governança, como boas práticas gerenciais integradas, uma vez que a integração vertical é inviável em diversos segmentos industriais.

Tendo ciência das vantagens e das desvantagens, o que se busca, em seguida, é adaptar as parcerias desse tipo de governança às distintas realidades de gestão em qualquer outro conjunto de organizações, processo conhecido como benchmark.

Em outras palavras, a questão seria desenhar a melhor estratégia de governança e de parceria que se aproxime mais da integração vertical sem onerar a empresa que adota essa estratégia na cadeia.

Uma parceria adequada para cada cadeia pode proporcionar benefícios competitivos e melhorias no seu desempenho (Pires, 2004; Neves, 2000 e Grant, 2002). Entretanto, o processo da análise da melhor estrutura de governança não é tão fácil e simples de se conduzir.

O trabalho de Zylbersztajn (1995) contribui no sentido de resgatar os estudos sobre governança e discutir a movimentação do ambiente institucional para o 
funcionamento do sistema econômico. O movimento econômico que está por detrás é complexo e nem sempre claro se comparado às atividades de parcerias entre empresas.

Senão, vejamos: no âmbito interno das empresas, diversas atividades do diaa-dia demonstram que a teoria sobre integração de atividades, processos, parcerias, cooperação e colaboração nas diversas cadeias de suprimentos ainda está além das práticas gerenciais.

Os esforços necessários para aplicar tais teorias demandam tempo, muita dedicação, alinhamentos das necessidades e paciência. Todavia, os descompassos internos são causados principalmente pela falta do alinhamento estratégico das atividades da cadeia de valor entre os elos da cadeia de suprimentos, da gestão e do planejamento não-integrados.

Diversas atividades de incentivo à compra antecipada, criação de elevados estoques em elos próximos aos clientes finais, alto capital de giro estocado ao longo da cadeia, promoções de preços pós-época de consumo ou validade próxima de sua data para a cadeia de alimentos são alguns dos descompassos observados que, na sua totalidade, prejudicam a lucratividade de todo um conjunto de organizações atuantes em uma cadeia de suprimentos.

Os objetivos e a visão da cadeia integrada não estão claros para todos os atores e o ótimo local ainda prevalece sobre o ótimo global. Isto implica remar individualmente de acordo com as suas necessidades pontuais, em detrimento do esforço conjunto em se atingir os interesses comuns.

A importância do gerenciamento da cadeia de suprimentos é tida como fator de sucesso em diversas empresas e deve aumentar no horizonte de cinco anos, tornandose atividade crítica num horizonte de três a quatro anos (Deloitte, 2002).

Além disso, percebe-se que o reflexo das atividades integradas de gestão está sendo trabalhado no desenvolvimento de executivos mais bem treinados para atuarem como diretores de supply chain management, termo comumente utilizado para designar a função. 
Tradicionalmente, a logística era vista como um conjunto de atividades operacionais, coordenadas por gerentes com baixo nível hierárquico. A evolução interna nas organizações por meio dos conceitos de logística empresarial elevou os níveis hierárquicos destes executivos, exercendo funções de segundo nível (diretoria) e terceiro nível (gerência sênior), abaixo do executivo-chefe de primeiro nível (presidência) (Figueiredo et al., 2003, p.50).

A análise dos principais papéis de um executivo-chefe nas empresas, em inglês CEO (Chief Executive Officer), indicou que o mais importante é garantir o alinhamento de todas as áreas funcionais com a estratégia competitiva organizacional integrada (Chopra \& Meindl, 2003).

As organizações estão em fase de consolidação de um cargo executivo que esteja apto a desempenhar e até desenvolver tais tarefas. Todavia, grande parte das empresas ainda não encontrou um modelo ideal para os papéis e responsabilidades deste executivo, de forma a oferecer uma visão integrada dos processos e a tomada de decisões sincronizadas e balanceadas que atendam ao alinhamento estratégico da cadeia ou que se enquadrem na melhor estrutura de governança.

Os casos que possivelmente fogem do problema mencionado são as cadeias integradas ou coordenadas verticalmente sob domínio de um elo central, normalmente exercido pelo elo fabricante.

Diante de todo esse cenário analisa-se a cadeia de frango no Brasil, que é um caso notório de sucesso gerencial e desenvolveu uma estrutura organizacional própria, haja vista o crescimento das organizações, vendas, exportações e faturamento ocorridos nas últimas décadas.

Segundo a Associação Brasileira dos Produtores e Exportadores de Frango (ABEF), o Brasil finalizou o ano de 2004 como o maior exportador do produto, tanto em divisas como em volume exportado, representando um aumento de $40 \%$ e $22 \%$, respectivamente, em relação a 2003. Atualmente, esta cadeia já participa do seleto grupo que exporta acima de US\$ 1 bilhão anual. 
A competição dessa cadeia está cada dia mais acirrada, mas o Brasil consegue crescer e liderar a "corrida". Entretanto, diversos problemas são enfrentados. Apesar da liderança, algumas abordagens gerenciais devem ser analisadas relativamente à sustentabilidade desse crescimento.

O estudo da cadeia do frango se mostra relevante na busca de boas práticas empresariais, pois como cita Pires (2004), o processo de desverticalização está em alta atualmente e esta cadeia caminha de forma vencedora sustentando a prática conciliatória da integração e da coordenação vertical.

Em termos estruturais, boa parte das empresas da cadeia do frango no Brasil possui uma estrutura de governança quase totalmente integrada verticalmente. Suas operações vão desde a fabricação de ração até a distribuição do alimento, com ou sem valor agregado ao produto, para o mercado final.

O ponto-chave da cadeia está no relacionamento com os criadores dos frangos, os chamados "integrados". Este elo da cadeia é gerenciado pelo modelo de coordenação vertical, sendo que a gestão continua seguindo o modelo da integração, mas os ativos não são mais pertencentes à empresa e sim terceirizados, um diferencial que reduz os investimentos em ativos imobilizados pelos gestores da cadeia.

O modelo que tais companhias utilizam pode trazer diversos benefícios na gestão integrada da cadeia de suprimentos, uma vez que sua administração é centralizada, podendo coexistir com a figura do gestor da cadeia e adaptação de estratégias por meio de todos os seus integrantes.

Taube-Netto (1996) estuda os benefícios trazidos pela integração do planejamento de diversas atividades em quase todos os elos da cadeia, resgatando dados do mercado e aplicando em dimensionamentos e programações de forma colaborativa.

Portanto, a motivação para o desenvolvimento do presente trabalho está inserida no que atualmente se intitula supply chain management, ou em português, gestão da cadeia de suprimentos, com foco na cadeia de frango. $\mathrm{O}$ estudo desta cadeia e 
como a estrutura organizacional e de governança integrada verticalmente é sustentável para serem analisados como potenciais fontes de benchmarks para outras organizações.

\subsection{Objetivos do trabalho}

O objetivo central desta dissertação é olhar o desenho de uma cadeia de suprimentos integrada verticalmente e sugerir uma metodologia de análise de divisão de custos para visualizar potenciais focos de benefícios ou problemas trazidos pelo referido modelo de governança na gestão desta cadeia, utilizando-se de métodos quantitativos e qualitativos.

Portanto, as principais questões a serem discutidas no presente trabalho são:

- Como as empresas ou elos da cadeia de suprimentos num ambiente integrado verticalmente geram, agregam e dividem custos da cadeia de valor?

- Quais os potenciais pontos focais de melhoria e otimização entre os elos da cadeia de suprimentos integrada verticalmente?

Para a discussão dos conceitos a serem apresentados, será desenvolvida uma proposta de adaptação de uma metodologia já existente e sua posterior aplicação para estudo de caso na cadeia do frango, tendo em vista a importância do papel que desempenha na economia do Brasil e a liderança obtida no mercado mundial.

A investigação dos questionamentos indicados acima abre espaço para sugestões na gestão dessa cadeia. Assim, os objetivos secundários são i) analisar qual o impacto de um alinhamento estratégico da cadeia de suprimentos segundo uma visão macro e ii) contribuir na discussão sobre integração vertical em cadeia de suprimentos. 


\subsection{Etapas e estrutura do trabalho}

Este trabalho é caracterizado como um estudo sobre estratégias de gestão da cadeia de suprimentos, governança via integração vertical e sua análise empírica via entrevistas feitas em uma empresa e uma associação da cadeia de frango a fim de validar a proposta.

Gestão da cadeia de suprimentos é um conceito recente e ainda pouco explorado no meio acadêmico (Pires, 2004). O caráter multidisciplinar e multifuncional do tema sugere pesquisas nas mais diversas áreas as quais serão resgatadas no decorrer do texto.

Assim, o conceito de cadeia de suprimentos ainda é algo amplo e engloba diversas áreas, atividades, aplicações e desenvolvimentos empresariais. Verificam-se nas várias literaturas publicadas sobre o tema que as atividades do dia-a-dia empresarial estão à frente dos estudos, contrariando o oposto tradicional em diversas áreas de pesquisa, como é o caso das práticas de parcerias citadas anteriormente.

É comum haver, nesse tema, um processo de busca das práticas empresariais e sua posterior análise conceitual na academia via estudos de casos, uma vez que a integração nas atividades empresariais já se encontra mais avançada que a integração das áreas acadêmicas. Assim, as pesquisas tentam conciliar diversas teorias das mais variadas áreas na busca de uma resposta unificada.

Nesse sentido, para o desenvolvimento do trabalho, além dos conhecimentos fundamentais relacionados à área de economia, complementação se fará necessária a partir de conceitos e práticas das áreas de marketing, administração e engenharia de produção. Percebe-se que a maioria dos conceitos já está mesclada nestas áreas, o que deverá facilitar o entendimento da cadeia de suprimentos e as eventuais interações de atividades e responsabilidades envolvidas.

A partir dessa sustentação teórica de natureza multidisciplinar, será realizada a análise de estratégias para cadeias de suprimentos, seguida da proposição e aplicação de um modelo de análise integrada dos custos e da agregação de valor na cadeia. 
Dos resultados a serem obtidos, espera-se obter uma forma de análise aplicável em outros tipos de governança. Ademais, serão consideradas hipóteses relacionadas aos benefícios trazidos pelo modelo de integração vertical no cenário de gestão da cadeia de suprimentos, com foco em custos, uma vez que há a presença da figura de um elo centralizador e tomador de decisões da cadeia integrada.

A Figura 1 ilustra a seqüência das fases do trabalho observada para realização da pesquisa, o que acabou por gerar este documento, organizado em seis capítulos, sumarizados a seguir.

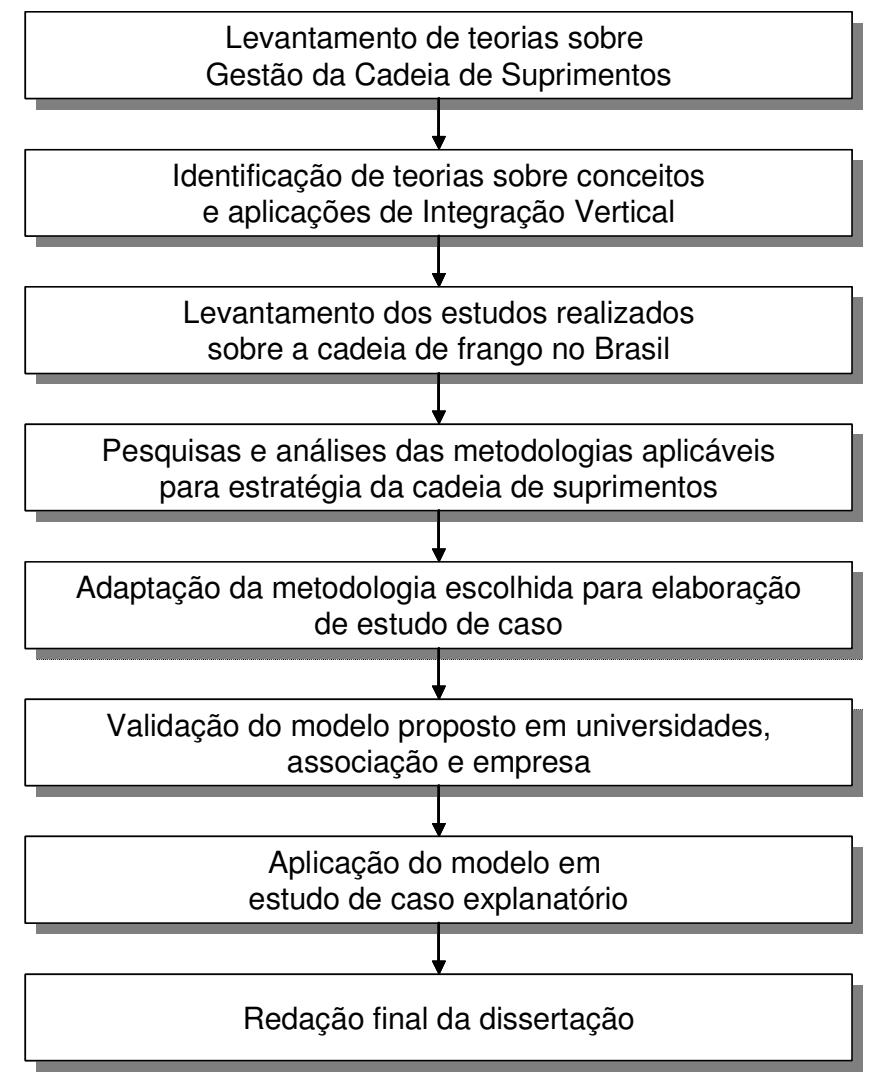

Figura 1 - Etapas seguidas para o desenvolvimento desta dissertação 
Capítulo 2: Referencial teórico - é o capítulo que contém a revisão bibliográfica que aborda dois temas principais: gestão da cadeia de suprimentos e integração vertical.

A revisão sobre alinhamento estratégico da cadeia estará embasada em estudos recentes. O foco será o gerenciamento integrado da cadeia de suprimentos, no sentido de fornecer uma metodologia de análise integrada dos custos envolvidos em cada estágio, em detrimento da explicação do porquê de uma outra estrutura de governança. Portanto, considera-se a integração vertical como ponto passivo de partida.

Já a revisão sobre integração vertical, embora venha sendo documentada de uma forma bastante diversificada nos diversos trabalhos científicos levantados, será abordada no âmbito do agronegócio e, posteriormente, com detalhe na cadeia do frango.

Portanto, a revisão de literatura resgata os principais conceitos para responder sobre a melhor forma de se analisar uma cadeia existente e não simplesmente quais as novas características dos sistemas agroindustriais que afetam as transações e que mudariam o sistema de governança.

Capítulo 3: A cadeia de frango no Brasil - este capítulo terá duas divisões

distintas. A primeira resgata a visão passado-presente da evolução da indústria de frangos no Brasil e a sua atual importância na economia nacional; a segunda ajusta este segmento do agronegócio às teorias expostas no Capítulo 2 sobre cadeia de suprimentos e governança via integração vertical.

Capítulo 4: Metodologia para análise de custos na cadeia de suprimentos - apresenta o modelo a ser adaptado e aplicado ao caso que se propõe estudar, assim como suas possíveis aplicações e restrições. Em seguida, a descrição da forma de condução do estudo de caso, de obtenção dos dados, das análises e dos resultados a serem obtidos.

Capítulo 5: Análise dos Resultados - os resultados empíricos do Capítulo 4 são apresentados, analisados e discutidos neste capítulo. Na sequiência, são 
apresentados alguns cenários adaptados ao estudo de caso, a partir da utilização da metodologia proposta.

Capítulo 6: Conclusões e Considerações Finais - apresenta a síntese dos resultados obtidos para o estudo de caso, assim como as recomendações de políticas e trabalhos futuros para esta linha de pesquisa. 


\section{REFERENCIAL TEÓRICO}

Este capítulo objetiva expor os principais conceitos necessários para o desenvolvimento do trabalho. Para tanto, serão apresentadas as definições de cadeia de suprimentos, de governança via integração vertical e sua aplicação na cadeia de frango no Brasil, objeto da pesquisa.

\subsection{Cadeia de suprimentos}

\subsubsection{Evolução, definição e objetivos}

Quando se estuda cadeia de suprimentos não se pode desvincular seu conceito daquele que se entende por logística, a qual vem passando por diversas mudanças em sua interpretação desde a sua concepção no contexto bélico até os dias atuais.

Vários autores usam o termo "logística" para designar diversas atividades nem sempre correlacionadas ou semelhantes. Destaca-se o conceito de Daskin (1995) citado por Caixeta-Filho (2004) ${ }^{1}$ que define logística como "planejamento e operação dos sistemas físicos, informacionais e gerenciais necessários para que insumos e produtos vençam condicionantes espaciais e temporais de forma econômica".

1 CAIXETA-FILHO, J.V. Transporte e logística em sistemas agroindustriais. Piracicaba, 2004. /Material de aula/ 
Atualmente, utiliza-se amplamente o conceito de logística como sinônimo de transporte e distribuição, desvinculando e minimizando o que realmente significa para o meio empresarial.

Russel (1998) afirma que o termo "logística" surgiu no meio militar por volta do século 18, sob influência francesa do verbo loger, em português, "abrigar". O maréchal des logis era o responsável pelo acampamento e aquartelamento das tropas, ou seja, a ele cabia garantir abrigo e provisões.

Com o passar do tempo houve diversas modificações, aperfeiçoamentos e evolução daquilo que foi originariamente concebido. Como em diversas atividades empresarias, o modelo bélico de gestão logística migrou para a indústria e, por volta da década de 50 (pós-Segunda Guerra Mundial), surgiu o que se entende por logística empresarial ou logística integrada.

Para Bowersox \& Closs (2001), a logística empresarial inclui todas as atividades de movimentação de produtos e a transferência de informações entre participantes de uma cadeia de suprimentos. Esta cadeia constitui uma estrutura lógica para que as empresas e seus fornecedores trabalhem em conjunto a fim de levarem produtos, serviços e informações, de maneira eficiente, aos consumidores finais.

Russel (1998) considera a logística como uma disciplina dividida em quatro subdisciplinas: logística militar ou de engenharia, logística empresarial, logística de eventos e processos logísticos. Todas são subdivisões do conceito inicial apresentado, mas com seus ramos de atuação e pesquisa de certa forma distintos. Para o presente trabalho, utilizar-se-ão os conceitos de logística empresarial.

Silva \& Musetti (2003) apresentam a evolução dos conceitos de logística contextualizados num cenário macroeconômico mundial e nos fatos históricos. $\mathrm{O}$ objetivo é entender a consolidação da atividade e do conceito de logística atualmente voltado para atender à gestão de toda uma cadeia de suprimentos.

A Figura 2 esquematiza essa evolução. Segundo os autores, a evolução atual se posiciona num cenário iniciado na década de 80 , marcado pela abertura econômica 
mundial, pelo advento da globalização e conseqüente aumento da competição. É também chamada de "Era da Informação", caracterizada pelo advento da Tecnologia da Informação (TI) e por um significativo avanço tecnológico tanto em produtos quanto em processos.

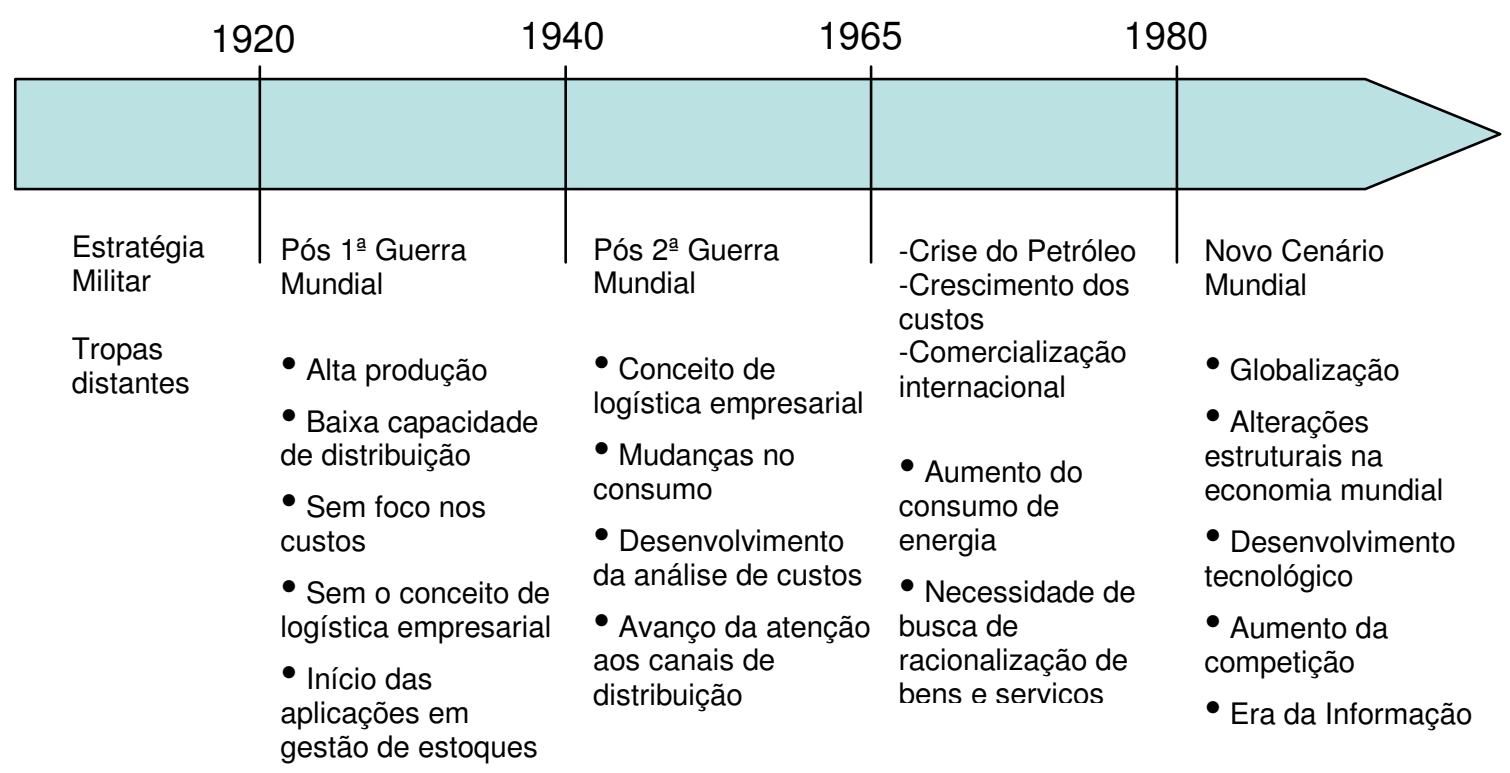

Figura 2 - Evolução do conceito de logística e suas implicações

Fonte: adaptado de Silva \& Musetti (2003)

No âmbito microeconômico, estudo realizado pela Associação Brasileira de Logística (ASLOG), em parceria com a Federação das Indústrias do Estado de São Paulo (FIESP) ${ }^{2}$, divide a evolução da logística com foco empresarial em cinco fases, com suas devidas implicações gerenciais, tal como reproduzido no Quadro 1.

Essa divisão foi aplicada no Brasil e mostrou que 5\% das empresas pesquisadas não se conscientizaram da importância de controlar e reduzir estoques; $65 \%$ estão entre as fases 0 e 1, com funções segregadas; $20 \%$ implementaram o conceito de logística integrada situando-se, portanto, na fase 2; $8 \%$ iniciaram implementações do

2 /Apresentado à 6. Conferência Anual da ASLOG, São Paulo, 2002/ 
tipo gestão da cadeia de suprimentos na fase 3 ; e $2 \%$ integram a gestão da cadeia de suprimentos com conceitos atuais de sistemas e de informática.

\begin{tabular}{|c|c|c|c|c|c|c|}
\hline & Fase 0 & Fase 1 & Fase 2 & Fase 3 & Fase 4 & Fase 5 \\
\hline Áreas & $\begin{array}{l}\text { Adm. de } \\
\text { Materiais }\end{array}$ & $\begin{array}{c}\text { Adm. de } \\
\text { materiais } \\
+ \\
\text { Distribuição }\end{array}$ & $\begin{array}{l}\text { Logística } \\
\text { Integrada }\end{array}$ & $\begin{array}{c}\text { Cadeia de } \\
\text { Suprimento } \\
\text { (SCM) }\end{array}$ & $\begin{array}{c}\text { Cadeia de } \\
\text { Suprimento } \\
+ \\
\text { Cooperação }\end{array}$ & $\begin{array}{c}\text { Cadeia de } \\
\text { Suprimento } \\
+ \\
\text { Cooperação } \\
+ \\
\text { Colaboração }\end{array}$ \\
\hline Focos & $\begin{array}{l}\text { - Gestão de } \\
\text { Estoques } \\
\text { - Gestão de } \\
\text { compras } \\
\text {-Movimentação } \\
\text { de materiais }\end{array}$ & $\begin{array}{l}\text { - Otimização do } \\
\text { sistema de } \\
\text { transportes }\end{array}$ & $\begin{array}{l}\text { • Visão } \\
\text { sistêmica da } \\
\text { empresa } \\
\text { • Integração } \\
\text { por sistema } \\
\text { de } \\
\text { informação }\end{array}$ & $\begin{array}{l}\text { - Visão sistêmica } \\
\text { da empresa, } \\
\text { incluindo } \\
\text { fornecedores e } \\
\text { canais de } \\
\text { distribuição }\end{array}$ & $\begin{array}{l}\text { - Amplo uso de } \\
\text { alianças } \\
\text { estratégicas, } \\
\text { subcontratação e } \\
\text { canais } \\
\text { alternativos de } \\
\text { distribuição }\end{array}$ & $\begin{array}{l}\text { - Ambiente } \\
\text { colaborativo para } \\
\text { gerenciamento } \\
\text { da cadeia }\end{array}$ \\
\hline
\end{tabular}

Quadro 1 - Fases de evolução da logística

Fonte: ASLOG (2002)

Do trabalho mencionado conclui-se que o foco administrativo atual das empresas brasileiras ainda se concentra na primeira fase, com esforços para atingir a segunda. Por outro lado, empresas na Europa e nos EUA já estão focando suas atividades entre a quarta e a quinta fases.

Mesmo assim, poucas companhias no mundo têm capacidade real de sincronização entre todos os elos de suas cadeias. Isto demonstra que há um importante caminho a seguir e a evoluir no cenário brasileiro. Portanto, a evolução empresarial e principalmente os estudos acadêmicos focam nas fases 3 e 4 .

Os conceitos de cadeia de suprimentos e ambientes colaborativos são chaves para o desenvolvimento deste trabalho. Ao citar o termo "cadeia", alguns estudiosos remetem para o conceito de "cadeia de valor", inicialmente concebido por Porter, conceituado economista acadêmico norte-americano na área de estratégia empresarial. Isto será mais bem discutido na seção 2.1.2.1. 
Diversos autores definem cadeia de suprimentos como sinônimo de rede de suprimentos, cadeias produtivas ou cadeia de abastecimento. Será utilizado o termo cadeia de suprimentos neste trabalho.

Chopra \& Meindl (2003) afirmam que uma cadeia de suprimentos engloba todos os elos envolvidos, direta ou indiretamente, no atendimento ao pedido de um cliente. Já o APICS Dictionary (Cox III \& Blackstone Junior, 1998) a define como as funções dentro e fora da empresa que possibilitam à cadeia de valor elaborar produtos e prover serviços a seus clientes.

Em termos gerais, Pires et al. (2001) consideram que uma cadeia de suprimentos é uma rede de companhias efetivamente responsáveis pela obtenção, fabricação e disponibilização de um produto ou serviço qualquer ao elo final, ou seja, o cliente. Percebe-se que a referência é feita a uma cadeia virtual, que não existe fisicamente, mas apenas em contratos administrativos ou relacionamentos gerenciais.

A rede de companhias deve ser desenhada ou estabelecida para descrever quais as são organizações atuantes. Neste caso, elos, membros, estágios ou rede de companhias são sinônimos. Via de regra, tal desenho segue o fluxo de transformação do produto. Uma cadeia de suprimentos típica pode envolver vários estágios. Portanto, a questão seria definir quais são os elos relevantes da cadeia de suprimentos.

Lambert et al. (1998) dizem que um fator-chave para se analisar uma cadeia de suprimentos é entender explicitamente a configuração da mesma.

Pires (2004) expõe que o primeiro passo para essa configuração é a definição de seus elos. Se todos os tipos forem considerados, haverá uma situação de extrema complexidade desnecessária e com possível perda do foco analítico. Os elos da cadeia podem ser desenhados como aqueles cuja empresa central (cuja função na cadeia é a mais forte em termos de poder de atuação, o que normalmente contempla a indústria de transformação) interage direta ou indiretamente de forma a agregar valor ao produto final. 
Lambert et al. (1998) dizem que os elos de uma cadeia de suprimentos podem ser divididos em elos primários e elos de suporte.

Os elos primários são todas as companhias ou negócios estratégicos que desenvolvem atividades operacionais ou de gestão nos processos de negócios necessários para produzir algo para um cliente ou mercado em específico.

Elos de suporte são todas as companhias que apenas oferecem recursos, conhecimento, utilidades ou ativos para os elos primários da cadeia de suprimentos.

É válido dizer que ambas não são excludentes, sendo que um elo da cadeia pode ser classificado em ambos.

Para se desenhar a configuração de uma cadeia de suprimentos, Chopra \& Meindl (2003) identificam cinco elos primários principais numa estrutura logística escalonada. São eles:

- Fornecedores de matéria-prima em vários níveis;

- Fabricantes;

- Atacadistas/Distribuidores (ou Centros de Distribuição);

- Varejistas;

- Clientes.

A Figura 3 mostra esquematicamente tal seqüência no sentido do fluxo do produto.

Fornecedor $\rightarrow$ Fabricante $\longrightarrow$ Distribuidor $\longrightarrow$ Varejista $\longrightarrow$ Cliente

Figura 3 - Elos primários principais de uma cadeia de suprimentos

Fonte: adaptado de Lambert et al. (1998), Bowersox \& Closs (2001) e Chopra \& Meindl (2003) 
Entretanto, não é preciso que a cadeia contemple todos os estágios ou elos citados. A utilidade de cada estágio está vinculada ao projeto da cadeia de suprimento com foco nas necessidades do cliente e no papel de cada estágio para atingi-las.

Assim, uma cadeia de suprimentos não inclui apenas fabricantes e fornecedores, mas também transportadoras, depósitos, varejistas e os próprios clientes. Dentro de cada organização inclui, ainda, atividades de desenvolvimento de engenharia, marketing, operações, finanças, dentre outras.

Coughlan et al. (2002) acrescentam que pode ser tentador remover um determinando estágio ou membro do canal para redução de custos ou aumento da margem para os membros atuais. Deve-se lembrar, porém, que os fluxos desenvolvidos nesta determinada etapa não serão eliminados, ou seja, suas funções precisam ser direcionadas para algum outro estágio para manter o fornecimento ao cliente final.

Pires (2004) comenta que o termo "gestão da cadeia de suprimentos" (GCS) é derivado do inglês supply chain management (SCM) e não possui um marco histórico de sua criação.

Entretanto, diversos artigos publicados nas décadas de 80 e 90, principalmente nesta última, apontam para a necessidade de integração entre atividades e departamentos internos das empresas para se promover a redução do custo de estoques e de distribuição.

Desse modo, começa-se a discutir a gestão da cadeia de suprimentos, que envolve as atividades principais de planejamento, organização e controle em todos estágios nela envolvidos, além das atividades internas das empresas (Cox III \& Blackstone Junior, 1998).

Russel (1998) afirma que gestão da cadeia de suprimentos é a integração colaborativa de todos os processos logísticos por todos os participantes de uma cadeia, desde os primeiros fornecedores até o usuário final.

Bertaglia (2003) e Pires (2004) citam que gestão da cadeia de suprimentos é a visão expandida de quatro grandes áreas empresariais: gestão da produção, logística, 
marketing e compras, cada uma delas desenvolvendo atividades específicas e principalmente conjuntas, eventualmente com sobreposição de tarefas e a necessidade de mudanças gerenciais.

É natural que cada área se expanda em funcionalidades e que conflitos surjam durante o processo. Este reconhecimento deve ser ponderado durante o desenvolvimento de atividades da gestão da cadeia de suprimentos. A Figura 4 esquematiza a visão pré e a visão pós da evolução.
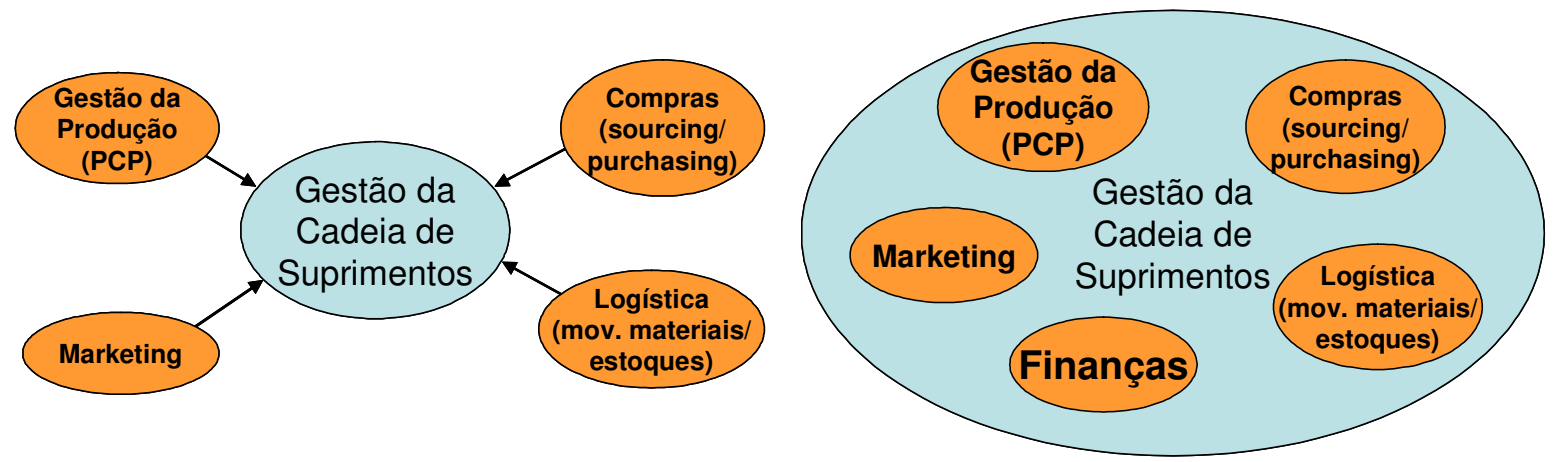

Figura 4 - Áreas empresariais departamentalizadas segregadas versus áreas empresariais funcionais integradas

Fonte: adaptado de Pires (2004)

Esse paradigma foi de certa forma absorvido com o advento de conceitos de reengenharia e posteriormente pelo desenvolvimento de processos de negócios, conhecido também como visão por processos. A idéia central é desenhar as diversas atividades de forma concatenada e integrada, sendo que cada uma delas deve ser realizada pelo seu "dono" antes de seguir para a próxima.

As atividades passam pelas áreas não mais de forma linear, mas de forma interpolada, de acordo com a necessidade do desenvolvimento das tarefas. Ou seja, a visão destas atividades passa de departamentalizada (linear) para segmentalizada (não linear) e há o complemento da área financeira como suporte aos processos. A citação de Bertaglia (2003) resume esta evolução: 
"Áreas que trabalhavam como silos isolados, no contexto de planejamento, compras, manufatura e distribuição com interfaces e limites claramente definidos, encontram-se agora agrupados em um único processo.” (Bertaglia, 2003, p.425)

Assim, Pires (2004) define gestão da cadeia de suprimentos como:

"Um modelo gerencial que busca atender as sinergias através da integração dos processos de negócios chaves ao longo da cadeia de suprimentos. O objetivo principal é atender ao consumidor final e outros stakeholders de forma mais eficaz e eficiente possível, ou seja, com produtos e/ou serviços de maior valor percebido pelo cliente final e obtido através do menor custo possível." (Pires, 2004, p.70)

Vê-se, portanto, que a literatura considera logística empresarial (ou integrada) como parte da gestão da cadeia de suprimentos, o que é muito confundido no dia-a-dia. Isto remonta às quatro subdisciplinas da logística citadas anteriormente por Russell (1998). A Figura 5 mostra esquematicamente as divisões conceituais de atuação. 


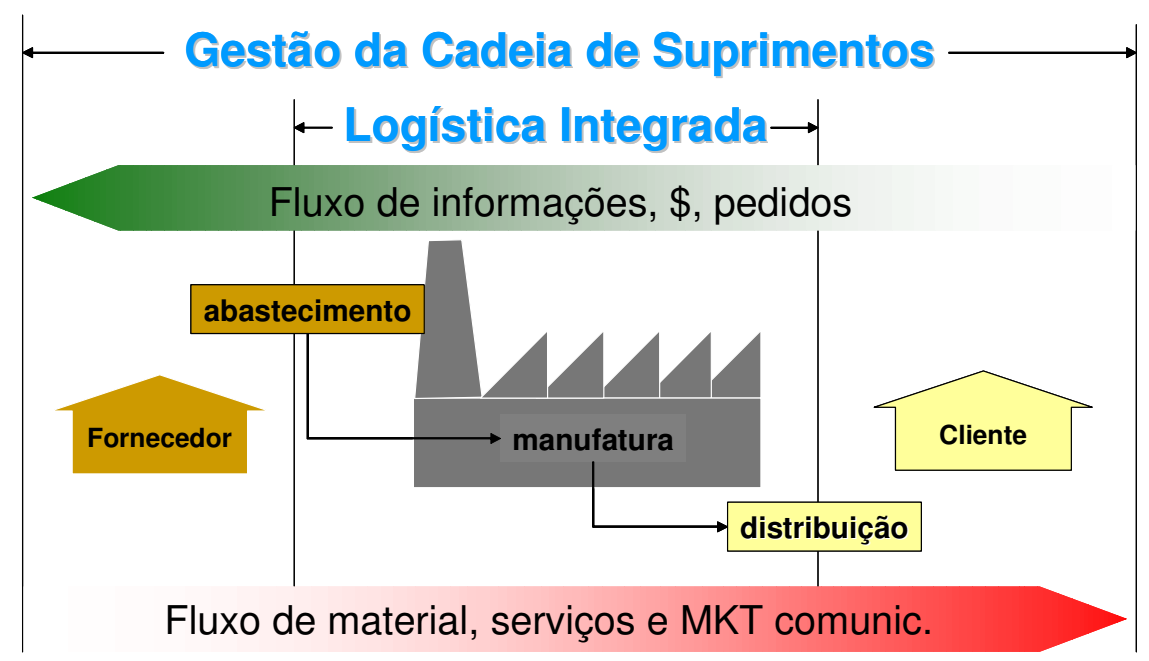

Figura 5 - Gestão da cadeia de suprimentos e logística integrada

Fonte: adaptado de Neves (1999), Musseti (2000), Ballou (2001), Chopra \& Meindl (2003) e Pires (2004)

Pela Figura 5, observa-se que a visão da esquerda para direita segue o fluxo de material ou serviços, sendo que o input é iniciado pelo fornecedor até alcançar o cliente final.

A comunicação de marketing segue o mesmo sentido, uma vez que as vendas, comercialização e entregas caminham paralelamente ao fluxo do produto ou serviço.

Em contrapartida, as informações de mercado seguem pelo sentido oposto, ou seja, da direita para esquerda. São os clientes que fornecem o input para as informações, assim como os pagamentos.

Paralelamente, ao se gerir uma cadeia de suprimentos, as atividades como gerenciamento de estoques, transportes, administração das instalações, preços, lucros, fluxo de informação e nível de serviço devem ser vistas de forma integrada para a cadeia e não mais trabalhadas na empresa separadamente.

A área de marketing pode fornecer uma boa forma de se analisar o negócio dessa maneira. Os chamados "fluxos de marketing", aplicados em canais de distribuição, 
caracterizam uma abordagem adequada para o dimensionamento das atividades necessárias para o funcionamento dos canais.

Elas agregam valor ao produto principalmente em termos de serviço, uma vez que não há mais transformação do mesmo. Logo, este conceito pode ser expandido e unificado para as outras áreas (logística, gestão da produção e compras) como sendo fluxos da cadeia de suprimentos.

O foco no cliente sugere um trabalho de adaptação de toda uma cadeia de organizações para que as mesmas alinhem suas atividades a este fim. Cabe aqui afirmar que o APICS Dictionary (Cox III \& Blackstone Junior, 1998) define nível de serviço como produto entregue na quantidade correta, no local certo, no momento especificado.

A própria ASLOG (2002), ao discorrer sobre a evolução do conceito de gestão da cadeia de suprimentos, indica que a criação de diversas atividades nos processos de negócios, envolvendo as quatro áreas da gestão da cadeia de suprimentos, aumenta naturalmente a sinergia existente.

Como resultado, há incremento do valor percebido na cadeia pela evolução das atividades gerenciais, segundo um efeito cascata, e cujos benefícios são indiretamente refletidos no produto final. A sinergia crescente entre as áreas é constantemente explorada nas organizações devido ao potencial de benefícios e melhorias adquiridos ao longo do tempo e que são percebidos indiretamente pelo cliente.

A definição de Pires (2004, p.20) indica o objetivo da gestão da cadeia de suprimentos com foco no cliente final. Chopra \& Meindl (2003) vão além, ao afirmarem que o objetivo de toda cadeia de suprimentos é maximizar o valor global gerado, quer seja para o cliente final, quer seja para toda a cadeia, independentemente do elo.

O conceito de valor é algo complexo e que merece uma certa atenção. Desde o seu uso em filosofia, religião, economia, marketing e administração, é algo subjetivo e que necessita de contextualização na tentativa de explicar o que se pretende. 
Obviamente, utilizar-se-ão dos conceitos desenvolvidos em economia, marketing e administração. Portanto, aplicam-se seus conceitos na análise de relações gerenciais no desenvolvimento de produtos, em estratégias empresariais e vendas.

Porter (1989) define "valor" como o montante financeiro que os compradores estão dispostos a pagar por aquilo que uma empresa lhes fornece em termos de produtos ou serviços. Uma empresa é rentável se o valor que ela consegue impor ultrapassar os custos envolvidos na criação ou na transformação de um produto ou serviço. Este valor tem reflexo direto no preço final.

Vale registrar que "valor" é diferente de "custo", uma vez que este deve ser menor que o valor gerado pela empresa. Do contrário, o cliente pagaria menos que o custo do produto ou serviço devido à sua propensão de pagar de acordo com o valor percebido. Assim, a busca pela criação de valor tanto físico como por serviços é algo almejado no meio empresarial.

Womack et al. (2004) afirmam que quem define o valor do produto ou do serviço é o cliente final e as organizações têm de buscar entender estas necessidades. Isto pode ser alcançado quando se questiona constantemente as antigas definições do negócio para saber o que é realmente necessário no desenvolvimento das atividades da organização.

Estendendo-se esse conceito para uma cadeia de suprimentos, entende-se por "valor global gerado" a diferença entre o valor do produto final percebido pelo cliente, refletido no preço que ele está disposto a pagar, e o esforço realizado pela cadeia para atender ao seu pedido, ou seja, o quanto cada estágio foi responsável pelo incremento do valor final.

O valor gerado pela cadeia está relacionado com a sua lucratividade, pois é a diferença entre a receita gerada pelo cliente e o custo total no decorrer da cadeia. Portanto, a lucratividade deve ser dividida entre todos os estágios da cadeia de suprimentos. 
Há duas questões-chave nessa discussão: a primeira é analisar quais são as atividades que realmente agregam valor ao produto e a segunda é saber qual a divisão mais adequada do valor global gerado na cadeia. Ambos questionamentos serão discutidos adiante, segundo a análise dos fluxos de marketing.

Pires (1998) mostra que a competição avançou do escopo empresarial para o escopo de cadeias de suprimentos, ou seja, cadeias virtuais competindo entre si para atraírem o cliente final. Pode, deste modo, concretizar o esforço realizado por um conjunto de empresas para conquistar a venda final. Portanto, o sucesso de uma cadeia de suprimentos é mensurado a partir da lucratividade total e não mais com base nos lucros de um estágio isolado.

Christopher (1998) acrescenta que o gerenciamento global da cadeia de suprimentos é o gerenciamento dos relacionamentos em todas as direções entre fornecedores e consumidores, para oferecer mais valor aos consumidores finais a um mínimo custo para toda a cadeia de suprimento. Logo, conclui-se que gerenciar esta cadeia envolve o controle dos fluxos entre seus estágios para maximizar a lucratividade total.

Integrar e gerenciar a cadeia de suprimentos é também integrar processos, os quais devem focar a lucratividade final. Tal integração é entendida como colaboração entre estágios compradores e estágios fornecedores, utilização de sistemas compatíveis, troca de informações comuns e até instalações físicas compartilhadas. Representa ir além da análise da cadeia de valor internamente às empresas para fora entre os seus relacionamentos, quais sejam, fornecedores e clientes.

Diversas práticas são utilizadas no meio empresarial com essas finalidades. Cita-se a do Efficient Consumer Response $(\mathrm{ECR})^{3}$, inicialmente concebida pelo elo varejista na cadeia de alimentos para sincronização de atividades de reposição; o Quick Response (QR) da indústria têxtil; o Just in Time II (JIT II), que é a extensão lógica do regime de produção Just in Time (JIT) para fora dos limites da empresa; e o

\footnotetext{
${ }^{3}$ ECR BRASIL. Biblioteca. http://www.ecrbrasil.com.br (06 maio 2005)
} 
Collaborative Planning, Forecasting and Replenishment (CPFR $)^{4}$, tido como uma evolução de práticas de integração na gestão de estoques já utilizadas pela indústria.

Nessas abordagens, a previsão de demanda do mercado, o planejamento de produção e o reabastecimento na cadeia são pensados em conjunto entre todos os elos da cadeia de suprimentos (Santa Eulália, 2001; Bertaglia, 2003).

\subsubsection{Estratégia na cadeia de suprimentos}

No escopo deste trabalho, estratégia será entendida como a forma de responder de que maneira uma função pode ser exercida para que forneça o melhor resultado. A estratégia da cadeia de suprimentos está intimamente relacionada à estratégia das organizações ou de cada estágio. Portanto, inicia-se a discussão pelos estágios da cadeia, ou seja, a empresa, separadamente, antes de iniciarmos a discussão sobre a cadeia integrada.

\subsubsection{A cadeia de valor}

Porter (1989) define estratégia competitiva como a busca de uma atuação competitiva favorável em uma organização que se empenha em estabelecer uma posição lucrativa e sustentável contra as forças que determinam a concorrência.

Grant (2002) a discute como sinônimo de estratégia do negócio. Portanto, está restrita ao âmbito de um estágio da cadeia de suprimentos, assim como no seu setor de atuação.

Porter (1989) ainda apresenta a idéia da vantagem competitiva, uma evolução da estratégia competitiva, ao introduzir o conceito de cadeia de valor, que pode

\footnotetext{
4 VOLUNTARY INTERINDUSTRY COMMERCE STANDARDS. CPFR®Committees.
} http://www.vics.org/committees (06 May 2005) 
ser encarada como a união de diversas funções que geram valor diretamente ou indiretamente ao produto ou serviço final da empresa.

Chopra \& Meindl (2003) apresentam uma cadeia de valor adaptada do modelo inicial de Porter (1989), válida para qualquer organização (empresa) e dividida em funções, conforme ilustra a Figura 6.

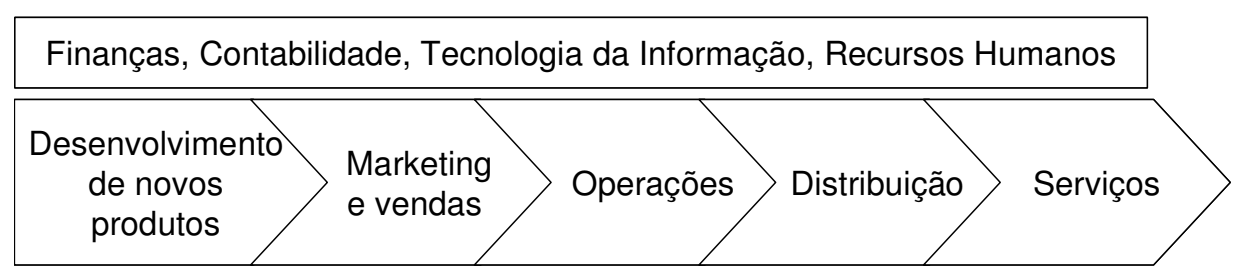

Figura 6 - A cadeia de valor em uma organização

Fonte: adaptado de Chopra \& Meindl (2003)

A cadeia de valor indicada é uma visão macro de funções que agregam valor, podendo diversas outras funções serem adicionadas à cadeia tanto na visão mais agregada como na menos agregada. Cada função é desenvolvida por um conjunto de atividades.

Há dois tipos essenciais de funções que criam valor ao produto. A primeira, de suporte, inclui aquelas atividades que facilitam o funcionamento da cadeia de valor (finanças/contabilidade, tecnologia de informação e recursos humanos).

A segunda inclui as funções primárias, ou seja, aquelas que realmente geram e criam valor para a cadeia de valor, tais como o desenvolvimento de novos produtos, marketing e vendas, operações, distribuição e serviço. Cada uma delas deve ser gerenciada, conduzida de forma estratégica e estar integrada às demais atividades.

De certa forma, Lambert et al. (1998) se basearam nessa divisão para classificar os elos de uma cadeia de suprimentos em primários e de suporte.

Assim, os elos da cadeia de suprimentos que desenvolvem atividades primárias na cadeia de valor receberão essa denominação, assim como para os que desenvolvem atividades de suporte serão classificados como elos de suporte. 
Desenvolvimento de novos produtos é a função cuja estratégia está relacionada com a inovação dos produtos e especificação para os mesmos. Já marketing e vendas são as funções estrategicamente desenvolvidas por atividades mais próximas ao cliente e ao mercado, trazendo informações externas para a empresa.

As operações transformam os insumos em produto final. Distribuição é relacionada às movimentações de materiais entre empresas, desde o fornecedor até o cliente. Já serviços são entendidos como as necessidades ou solicitações dos clientes durante a venda e no pós-venda.

Como cada empresa possui a sua própria estratégia competitiva e conseqüentemente a sua cadeia de valor, inserida em uma cadeia de suprimentos integrada, esta estratégia não pode ser planejada e gerenciada, isoladamente, pelo foco da lucratividade. Portanto, existe uma relação direta entre a estratégia competitiva e a estratégia da cadeia de suprimentos, segundo análise da cadeia de valor exposta na Figura 6, válida para uma empresa.

Ao se extrapolar o conceito de cadeia de valor de uma organização para uma cadeia de suprimentos, Chopra \& Meindl (2003) sugerem a união das três últimas funções da Figura 6, que podem ser especificadas como as funções principais da cadeia de valor para a estratégia da cadeia de suprimentos. São elas as operações, a distribuição e os serviços, que merecem tratamento gerencial integrado.

De acordo com os autores mencionados, no desenho da cadeia de valor, as funções de marketing não entram no alinhamento estratégico da cadeia, o que está em contraposição ao que foi escrito anteriormente. Entretanto, é necessário entender que para Chopra \& Meindl (2003) a função de marketing desenvolve apenas atividades de vendas e contatos com clientes. No presente trabalho, marketing será considerado mais do que isto e será tratado como parte da estratégia da cadeia de suprimentos.

Para cada uma das funções desenvolvidas na cadeia de valor aparecem os fatores-chave para o desenrolar da estratégia da cadeia de suprimentos. Tais fatores são as macroatividades operacionais da gestão da cadeia de suprimentos. 
As principais macroatividades envolvem estoques (dimensionamento e gestão), transportes (infra-estrutura e gestão), dimensionamento de instalações (como depósitos, fábricas, CDs etc.), tecnologia de informação e movimentação de materiais (Chopra \& Meindl, 2003; Bowersox \& Closs, 2001; Ballou, 2001).

Cada uma delas merece seu próprio desenvolvimento e possui áreas de conhecimento específicas, normalmente sendo trabalhadas no âmbito da gestão da cadeia de suprimentos tático-operacional.

Abaixo das funções-chave aparecem as atividades propriamente ditas. São elas que atuam diretamente na cadeia e que agregam valor ao produto ou serviço. A necessidade surge no exame de todas as atividades na tentativa de verificar quais realmente criam valor e na união de esforços para que elas sejam constantemente melhoradas. Mais adiante, tais atividades serão batizadas de fluxos de cadeia de suprimentos. Todas são concatenadas em processos de negócios, sendo que para cada uma há uma área responsável pela sua execução.

Entretanto, outras versões são observadas para o gerenciamento da cadeia de suprimentos, derivados da cadeia de valor. Mais do que isto, Bond (2002) define que para a medição do desempenho de uma cadeia de suprimentos os indicadores funcionais estão relacionados com os processos de compras, manufatura (ou produção), logística e vendas, praticamente as mesmas áreas citadas por Pires (2004) na Figura 4 e mais específicas que aquelas apontadas por Chopra \& Meindl (2003).

A medição do desempenho da cadeia deve ser realizada para fornecer comparação ao que se pratica no mercado e para verificar o eventual grau de conflito existente entre as áreas. Tudo isto de acordo com Womack et al. (2004), segundo os quais qualquer atividade deve ter um bom sistema de medição de desempenho, antes de qualquer outra coisa, para ser bem gerenciada.

De fato, todas as versões se alinham com a metodologia do Supply Chain Operations Reference Model (SCOR) de medição e configuração de uma cadeia de suprimentos em quatro grandes processos de negócios ou atividades que agregam valor à 
cadeia (planejar, abastecer, produzir e entregar) (Bond, 2002) e que são usadas para descrever uma cadeia de suprimentos simples ou complexa.

Pires (2004) cita que o modelo SCOR é considerado o pioneiro como modelo de referência que descreve, comunica, avalia e melhora o desempenho da cadeia de suprimentos. Decisões sobre estoques, instalações e fluxos de informação também entram nesse espectro, os quais foram chamados de fatores-chave anteriormente.

Assim, estratégia da cadeia de suprimento pode ser definida como a estratégia alinhada de todas as funções da cadeia de valor, dos fatores-chave e das atividades necessárias relacionadas para a gestão integrada.

Womack et al. (2004) ainda acrescentam que todas as três devem ser desenvolvidas com o intuito de atingir um custo-alvo, estipulado de acordo com os preços especificados de venda dos produtos e a margem de lucro adequada para a cadeia. Todo o esforço do desenvolvimento da estratégia da cadeia de suprimentos deve se embasar para atingir tal custo e eliminar desperdícios.

Em suma, cada versão busca a sua melhor acomodação para utilizar o modelo proposto. Para dar continuidade aos conceitos e às teorias, serão utilizadas as quatro áreas de gestão da cadeia de suprimentos que agregam valor no desenvolvimento das atividades da cadeia de valor: logística, marketing, produção e finanças, ilustradas na Figura 4.

Logística, no sentido comum, reúne todas as atividades relacionadas ao transporte, armazenagem física e gestão de pedidos. Marketing agrega as atividades de gestão do canal de distribuição, vendas, comercialização e estoques. Produção desenvolve as atividades operacionais produtivas e finanças respondem pela área financeira da gestão integrada.

As atividades relacionadas com compras serão alocadas na área de marketing, mais especificamente em comercialização. Mais adiante, ao ser analisada a questão da integração vertical (vide seção 2.2.2), será mostrado o porquê de a área de 
compras não ter mais tanta importância como em organizações independentes (é a análise do make-or-buy).

\subsubsection{Análise do tipo de cadeia de suprimentos}

A seção anterior mostrou que, para a empresa atuar num ambiente integrado, há a necessidade do alinhamento estratégico organizacional da cadeia de valor com as necessidades da cadeia de suprimentos entre todos os elos. Este alinhamento diz respeito às estratégias competitivas, corporativas e as da cadeia de suprimentos com os mesmos objetivos.

Uma atividade realizada de forma descompassada pode arruinar toda a cadeia de suprimentos, ao passo que uma única atividade não é capaz de assegurar o sucesso da cadeia inteira.

Pesquisa realizada pela Deloitte (2002) no Brasil mostrou que $89 \%$ das empresas entrevistadas afirmam possuir essas estratégias alinhadas (nota-se que as escolhidas para entrevistas são as líderes de mercado e as principais em seus respectivos segmentos).

Segundo Grant (2002), existe uma distinção entre estratégia corporativa e estratégia do negócio, sendo esta última mais conhecida como estratégia competitiva. Tal diferenciação pode ser vista sob outra ótica ao se afirmar que estratégia corporativa se preocupa com o "onde" a empresa compete e estratégia competitiva se preocupa com o "como" isto se dá.

Sendo a cadeia de suprimentos uma possível composição de empresas, não é possível estudar a estratégia do negócio separadamente, mas sim a estratégia coorporativa, uma vez que decisões deste âmbito envolvem o escopo da empresa atuante com os outros estágios. Assim, três questões são postas para se estabelecer a estratégia corporativa de uma empresa com visão na cadeia de suprimentos:

- Escopo do produto: quão especializada a empresa deve ser em termos de gama de produtos oferecidos? 
- Escopo geográfico: qual é o domínio geográfico de atuação das atividades da empresa?

- Escopo vertical: qual a gama de atividades verticais em que a empresa deve atuar?

As respostas passaram por diversas mudanças ao longo do tempo. A revisão bibliográfica se atém apenas ao que se propõe estudar e o que se comenta no contexto atual do tema desta dissertação, em detrimento da reflexão detalhada da evolução. Portanto, apenas o escopo do produto (na seqüência) e o escopo vertical (na seção 2.2.2) serão mais detalhados e comentados. ${ }^{5}$

Porter (1989) chama o escopo do produto de escopo de segmento e discute a necessidade de se adaptar o produto ao mercado e ao consumidor. Para isto, propõe que sejam seguidas metodologias de desenho e posteriormente feitas mudanças na cadeia de valor proposta e no grau de enfoque dado para atender às exigências mercadológicas e técnicas na concepção do produto. Com este objetivo, a cadeia de valor da Figura 6 será o alicerce para o embasamento das decisões.

Já Fisher (1997) discute o escopo do produto sob a ótica mercadológica como sendo funcional ou inovador, além de frisar a estratégia da cadeia de suprimentos diferenciada para cada tipo de produto. $\mathrm{O}$ alinhamento estratégico da gestão da cadeia de suprimentos é direcionado de acordo com esta classificação de produtos.

Em seu estudo, Proud (1999) ${ }^{6}$, citado por Santa Eulália (2001, p.65), afirma que "demanda é a faísca que faz a ignição de todo o sistema econômico de uma cadeia de empresas", definição importante na classificação dos produtos sugerida por Fischer (1997).

\footnotetext{
${ }^{5} \mathrm{O}$ item de escopo geográfico traz à tona questões relacionadas às áreas geográficas com atuação dos canais de distribuição e logística de transporte. Como fogem do foco do trabalho, não serão aqui discutidos tais fatores.

${ }^{6}$ PROUD, J.F. Master scheduling: a practical guide to manufacturing. New York: John Wiley, 1999. 210p.
} 
Os produtos funcionais são encarados como aqueles que satisfazem as demandas básicas dos consumidores. Via de regra, são os já consagrados no mercado e cujas informações necessárias para qualquer planejamento e gestão são de conhecimento geral.

Diversas empresas estão aptas a produzi-los e a concorrência é mais latente. Não possuem variações bruscas e sazonais da demanda, ou se possuírem, costumam ser conhecidas, o que gera mais assertividade dos números de demanda de mercado projetada. Por fim, possuem ciclos de vida mais longos, maiores que cinco anos.

Esses fatores geram aumento da competição e diminuição dos lucros das empresas. Um bom exemplo é o frango inteiro abatido e empacotado, uma vez que é uma commodity mundial.

Em muitos casos, para aumentar as margens dos lucros, muitas empresas implementam inovações em seus produtos a fim de diferenciá-los daqueles já conhecidos no mercado (funcionais).

Rizzi (1993) cita que a inovação é a diferenciação de produtos como mecanismo de concorrência. Esta atividade gera, por diversas vezes, incerteza na demanda, diminuição do ciclo de vida devido à imitação dos produtos, baixa aceitação de consumo e a necessidade de investimentos para desenvolver novos produtos, chamados de "inovadores".

Bons exemplos desse tipo de produto são os cortes especiais, a industrialização da carne, os congelados prontos para consumo (que utilizam equipamentos mais modernos como microondas para finalizarem o processo de cozimento ou fritura), dentre outros.

O Quadro 2 contrapõe os aspectos para cada produto e seu impacto na demanda na cadeia de suprimentos.

Seguindo a classificação por produtos, Fisher (1997) acrescenta a necessidade da adaptação das funções e das atividades da cadeia de valor para o gerenciamento da cadeia de suprimentos de acordo com o tipo de produto, cuja visão 
mercadológica vai guiar as adaptações necessárias para dois tipos de configuração de cadeia de suprimentos: a chamada cadeia eficiente e a chamada cadeia responsiva.

\begin{tabular}{|l|c|c|}
\cline { 2 - 3 } \multicolumn{1}{c|}{} & \multicolumn{1}{c|}{$\begin{array}{c}\text { Produto } \\
\text { Funcional }\end{array}$} & $\begin{array}{c}\text { Produto } \\
\text { Inovador }\end{array}$ \\
\hline Aspectos da demanda & previsível & pouco previsível \\
\hline Ciclo de vida do produto & mais de 2 anos & de 3 meses a 1 ano \\
\hline Margem de contribuição & de 5\% a 20\% & de 20\% a $60 \%$ \\
\hline Variedade do produto & baixa & alta \\
\hline Média de erros da previsão & $10 \%$ & de $40 \%$ a $100 \%$ \\
\hline $\begin{array}{l}\text { Média de quebra de } \\
\text { estoques }\end{array}$ & de 1\% a $2 \%$ & de $10 \%$ a $40 \%$ \\
\hline $\begin{array}{l}\text { Média de promoção do } \\
\text { produto após o término de } \\
\text { sua estação em relação ao } \\
\text { preço praticado }\end{array}$ & $0 \%$ & de $10 \%$ a $25 \%$ \\
\hline $\begin{array}{l}\text { Tempo necessário para } \\
\text { entrega de produtos } \\
\text { fabricados sob demanda }\end{array}$ & de 6 meses a 1 ano & de 1 dia a 2 semanas \\
\hline
\end{tabular}

Quadro 2 - Aspectos comparativos entre produto funcional e produto inovador

Fonte: adaptado de Fisher (1997)

Entende-se por cadeia eficiente a organização de todas as funções e atividades da cadeia de valor e da gestão da cadeia de suprimentos direcionadas para atender fisicamente à demanda de mercado ao menor custo.

Pires (2004) chama esse tipo de cadeia de enxuta, como uma propagação do modo de produção enxuta (do inglês, lean production) interna às fábricas, concebida no mundo oriental e muito difundida nas indústrias em geral.

Suas atividades focam a redução de desperdícios e anomalias ao longo dos elos, pois as incertezas ou novidades que tais produtos poderiam enfrentar já foram ultrapassadas. Mesmo assim, usam o princípio de produção empurrada ${ }^{7}$.

Práticas de otimização para a cadeia de valor envolvendo produção, distribuição, aumento da produtividade para redução de custos e ganhos em economia de

\footnotetext{
${ }^{7}$ Entende-se por produção empurrada a fabricação dos produtos de acordo com uma previsão de demanda, antevendo os movimentos do mercado e empurrando os produtos para estoque. Já na produção puxada, cada elo "puxa" a produção do seu elo anterior para suprir a real demanda de mercado.
} 
escala são os diferenciais que premiam a cadeia como ganhadora de pedidos. Normalmente, esta estratégia de cadeia é mais bem adaptada para produtos funcionais.

Por outro lado, cadeia responsiva é aquela que organiza todas as atividades da cadeia de valor e da gestão da cadeia de suprimentos para atender à demanda final da forma mais ágil possível, ou seja, na busca da velocidade de resposta, sendo sensitiva ao mercado.

As mudanças rápidas do mercado são administradas com mais sucesso por esse tipo de cadeia. Os estoques são alocados e administrados a fim de se proteger contra as incertezas da demanda e do mercado, sem priorizar a minimização dos custos como na cadeia eficiente, mas em momento algum desmerecendo a sua importância.

No caso, tanto os elos à jusante quanto à montante do elo central devem ser administrados e escolhidos de acordo com a sua velocidade e flexibilidade na entrega dos produtos e não em função do menor custo. Diversos autores comentam que esta estratégia de cadeia está baseada no tempo.

Christopher (2000) citado por Pires (2004) chama a cadeia responsiva de “ágil” e o critério ganhador de pedidos é a disponibilidade do produto. Normalmente, ela se adapta melhor aos produtos inovadores. De uma certa forma, é possível dizer que tal cadeia é uma extrapolação dos conceitos de produção puxada.

Pires (2004) acrescenta que, em diversos casos, ambas as cadeias atuam conjuntamente, dependendo do sistema de produção adotado ou da estratégia para critério ganhador do pedido. Antes de qualquer coisa, é necessário saber se o produto a ser comercializado é funcional ou inovador no dimensionamento da cadeia por inteiro.

Mesmo assim, é possível que em parte da cadeia seja interessante a gestão eficiente e, em outra, a gestão responsiva. Uma mesma empresa ou a cadeia toda que possuam ambos os produtos dificultam esta separação e sugerem a mescla.

Para Bertaglia (2003), as duas estratégias não são excludentes e podem ser combinadas entre si. Christopher (2000) vai além e afirma que trabalhar com ambas num sistema híbrido é a melhor combinação para qualquer cadeia. O desafio está em saber 
em que ponto acaba uma e começa a outra estratégia, conhecido como ponto de desacoplamento.

É o caso, por exemplo, da cadeia do frango, uma vez que os canais de distribuição, os sistemas de transportes, o gerenciamento dos fornecedores e a gestão da cadeia são compartilhados entre quase todos os produtos, sejam eles inovadores ou funcionais.

O Quadro 3 resume os aspectos das estratégias eficiente e responsiva de cadeias de suprimentos.

\begin{tabular}{|c|c|c|}
\hline & Cadeia Eficiente & Cadeia Responsiva \\
\hline Função principal & $\begin{array}{l}\text { Oferta pela demanda } \\
\text { previsível ao menor } \\
\text { custo possível }\end{array}$ & $\begin{array}{l}\text { Resposta rápida às variações } \\
\text { imprevisíveis da demanda para } \\
\text { minimizar quebra de estoques, } \\
\text { promoções e estoques } \\
\text { obsoletos }\end{array}$ \\
\hline Estratégia de preços & Margens baixas & Margens altas \\
\hline Estratégia de manufatura & $\begin{array}{l}\text { Alto índice de } \\
\text { utilização do } \\
\text { maquinário }\end{array}$ & $\begin{array}{l}\text { Gerenciar excesso de } \\
\text { capacidade }\end{array}$ \\
\hline Estratégia de estoques & $\begin{array}{l}\text { Alto giro de estoques } \\
\text { e minimizar estoques } \\
\text { ao longo da cadeia }\end{array}$ & $\begin{array}{l}\text { Gerenciar estoques } \\
\text { significativos ao longo da } \\
\text { cadeia para antender as } \\
\text { variações da demanda }\end{array}$ \\
\hline Tempo de entrega & $\begin{array}{l}\text { Baixo tempo de } \\
\text { entrega ao mesmo } \\
\text { custo }\end{array}$ & $\begin{array}{l}\text { Investimento direto para } \\
\text { diminuir os tempos de entrega, }\end{array}$ \\
\hline Escolha de fornecedores & $\begin{array}{l}\text { Foco no preço e } \\
\text { qualidade }\end{array}$ & $\begin{array}{l}\text { Foco na flexibilidade, } \\
\text { velocidade de entrega e } \\
\text { qualidade }\end{array}$ \\
\hline Estratégia de novos produtos & $\begin{array}{l}\text { Maximizar } \\
\text { desempenho e } \\
\text { minimizar custo } \\
\end{array}$ & $\begin{array}{l}\text { Usar desenho modular para } \\
\text { postergar a diferenciação o } \\
\text { mais próximo ao cliente }\end{array}$ \\
\hline Estratégia de transportes & $\begin{array}{l}\text { Otimizar o uso do } \\
\text { transporte para } \\
\text { minimizar custos }\end{array}$ & $\begin{array}{l}\text { Utilizar meios de transporte } \\
\text { responsivos }\end{array}$ \\
\hline
\end{tabular}

Quadro 3 - Aspectos gerenciais da cadeia eficiente versus cadeia responsiva

Fonte: adaptado de Fisher (1997) e Chopra \& Meindl (2003)

Assim, a separação por tipo de produto torna-se apenas teórica e, neste caso, o dimensionamento das estratégias híbridas pelo ponto onde termina uma e começa a 
outra deve ser feito de acordo com o ganho econômico, o ganho de produção e a necessidade do mercado, discussão que será retomada durante o estudo de caso.

De alguma forma, é possível afirmar que as cadeias responsivas tendem a se tornar eficientes com o passar do tempo, uma vez que as novidades e incertezas do mercado começam a perder força e o ponto de desacoplamento fica mais claro.

Os produtos tornam-se conhecidos, diversas cadeias concorrentes passam a produzir itens semelhantes e questões-chave, como a demanda, podem ser dimensionadas com mais exatidão. Ou seja, os produtos passam de inovadores para funcionais apenas por uma questão de tempo se não forem propostas modificações que sustentem a classificação inicial.

Um bom exemplo é o cinto de segurança de três pontos em automóveis. Inicialmente era um fator diferencial, passível de propaganda e ganhador de pedidos nas vendas. Atualmente é qualificador, o que significa dizer que se um automóvel não o possuir a venda não se concretiza, e o dimensionamento da sua produção segue exatamente o das previsões de automóveis.

De posse da descrição do tipo de produto e da configuração da cadeia de suprimentos adaptada será feita a análise de como realizar o alinhamento estratégico. A próxima seção abordará questões sobre como realizar as atividades-chave da cadeia de valor após ter em mãos toda a cadeia desenhada, definida, dimensionada e entendida por meio do alinhamento estratégico.

\subsubsection{O alinhamento estratégico na cadeia de suprimentos}

Fisher (1997) discute que uma cadeia de suprimentos desenvolve dois tipos de função: a física e a de mediação com o mercado. A primeira refere-se à fabricação e à conversão da matéria-prima em partes, componentes ou produtos finais. Já a de mediação com o mercado busca garantir que a variedade de produtos atinja as expectativas dos clientes finais. 
Ambas as funções envolvem custos, sendo que os físicos dizem respeito aos de produção, transporte e gerenciamento de estoques. Já os de mediação com o mercado surgem quando há problemas com a demanda, isto é, quando a oferta do produto é maior do que a procura por parte do mercado, gerando estoques e necessidade de políticas de desconto, ou quando a oferta é menor que a demanda, resultando em perda de vendas e insatisfação dos clientes.

Quaisquer das situações citadas provocam a necessidade do gerenciamento ou gestão da demanda, que "tem como objetivo coordenar e controlar todos os fatores de demanda para que o sistema produtivo possa ser utilizado com eficiência e para que os prazos de entrega dos produtos sejam cumpridos" (Santa Eulália apud Chase \& Aquilano, 1995, p.65).

Portanto, o alinhamento estratégico da cadeia de suprimentos tenta conciliar as estratégias corporativas e competitivas empresariais com as da cadeia de suprimentos. Chopra \& Meindl (2003) dividem a realização do referido alinhamento em três grandes fases:

1. Entender o cliente (ou o mercado);

2. Entender a cadeia de suprimentos;

3. Realizar o alinhamento estratégico.

A primeira fase procura identificar como é o comportamento do mercado e dos clientes finais. Busca-se obter dados para dimensionar o tamanho do lote, o tempo de resposta que clientes estão dispostos a esperar, a variedade de produtos necessária, o nível de serviço, o preço a ser estabelecido, o comportamento da demanda etc. São dados operacionais com utilidade para o dimensionamento do sistema produtivo, de distribuição, de abastecimento e de gestão da demanda.

A segunda fase tenta entender qual a melhor forma de atuação da cadeia de suprimentos no mercado, de acordo com as definições da primeira: eficiente ou responsiva, híbrida e o ponto de desacoplamento. Esta fase deve estar de acordo com a estratégia do escopo do produto em funcional ou inovador. 
A terceira fase se caracteriza por combinar os dois primeiros fatores, de forma que a estratégia para a gestão da cadeia de suprimentos possa ser sustentada pela cadeia de valor. Este alinhamento pode ser desenhado segundo o entendimento do grau de incerteza da demanda para os produtos em questão e o posicionamento da cadeia conforme a necessidade de responsividade e eficiência, assim como o que deve ser puxado e o que deve ser empurrado na cadeia.

A finalização da terceira fase e, por conseqüência, de todo o alinhamento estratégico, ocorrerá quando os fatores-chave estiverem desenhados para que mais coerentemente se adaptem ao que as estratégias da cadeia pedem. Será necessário dimensionar qual a melhor estratégia de operações, de fornecedores (supply) e de logística.

Esse cenário deve ser dinâmico, uma vez que a evolução dos negócios, a participação no mercado, o ciclo de vida e a maturidade dos produtos mudam com o passar do tempo. Logo, as necessidades de revisão das fases e políticas a serem adotadas devem ser mapeadas constantemente.

A Figura 7 mostra como pode ser administrada a dinâmica das mudanças citadas, ao localizar e acompanhar a cadeia de suprimentos na zona de alinhamento estratégico durante a evolução do seu ciclo de vida e também do produto.

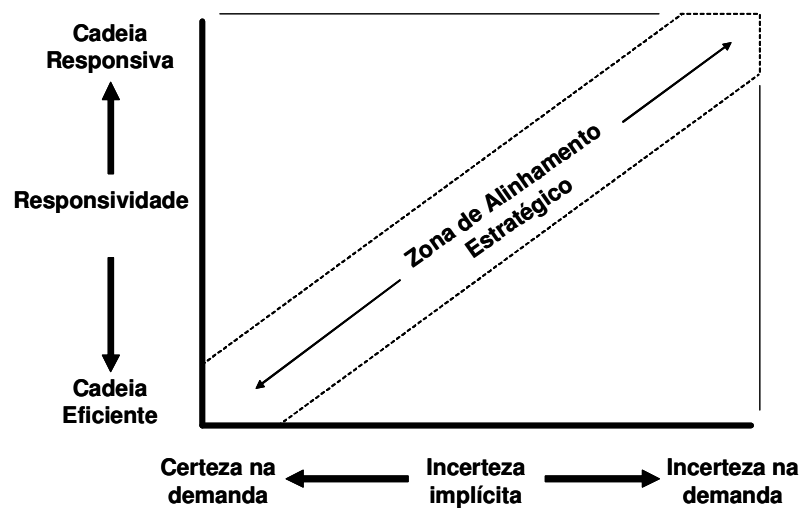

Figura 7 - Zona de alinhamento estratégico e mudanças na estratégia da cadeia de suprimentos durante a evolução do ciclo de vida do produto

Fonte: adaptado de Chopra \& Meindl (2003) 
O alinhamento estratégico estará completo quando todas as estratégias funcionais da cadeia de valor estiverem coerentes, sustentarem a estratégia competitiva e os fatores-chave estiverem dimensionados. O resultado será o posicionamento da cadeia dentro da zona de alinhamento estratégico da Figura 7.

\subsubsection{A cadeia de suprimentos no ambiente do agronegócio}

A literatura usa o conceito de Sistema de Agronegócio (SAG) como o estudo de cadeias no ambiente do agronegócio. Zylbersztajn (1995) caracteriza um SAG como um enfoque sistêmico de evolução de diversos tipos de empresas atuantes nas atividades de produção agrícola e agropecuária, segundo a teoria conhecida como Enfoque do Sistema de Commodities, do inglês Commodity Systems Approach (CSA). Esta visão trouxe base para se introduzir a questão de dependência intersetorial e o grau de intensidade das ligações, como mostra a Figura 8.

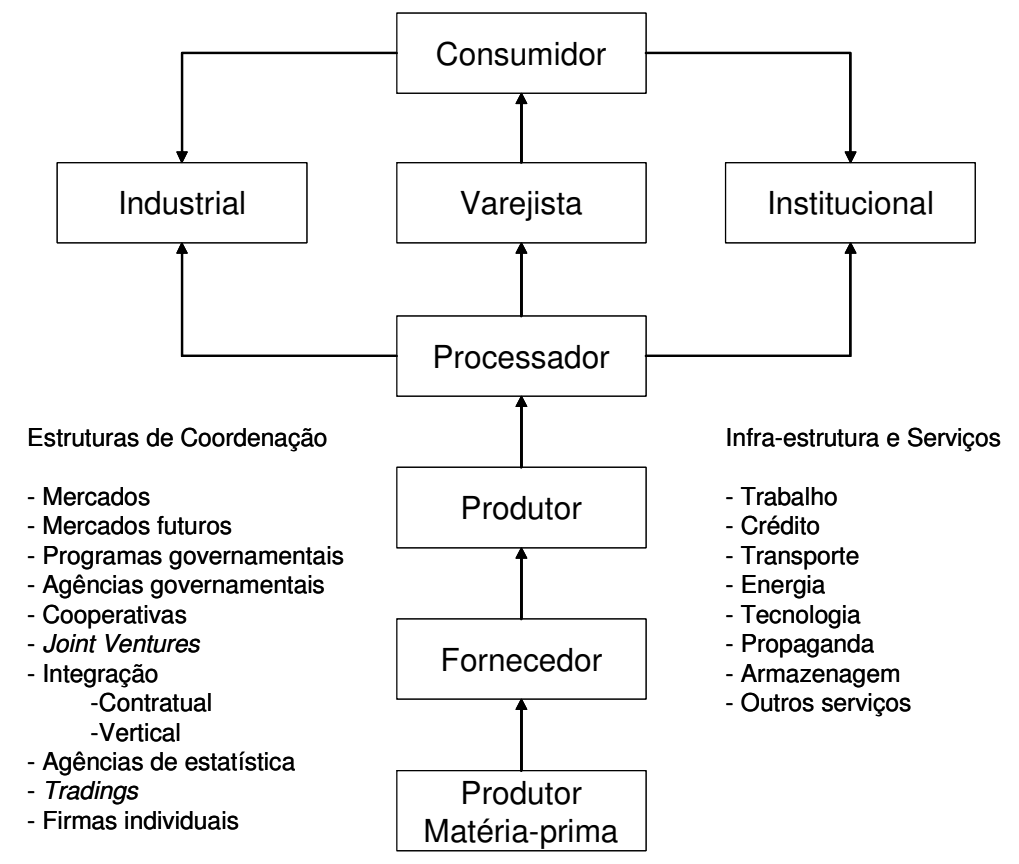

Figura 8 - Enfoque de sistemas de agronegócios

Fonte: adaptado de Zylbersztajn (1995) 
No centro da Figura 8 há a especificação da cadeia, aqui chamada de SAG, e duas visões analíticas: industrial e institucional. À direita do SAG, podem ser vistas as atividades centrais da cadeia de valor e fatores-chave operacionais do seu funcionamento, batizados de infra-estrutura e serviços. À esquerda, estão as estruturas de coordenação possíveis para qualquer SAG, cuja estrutura de integração vertical será detalhada no decorrer do trabalho.

Goldberg (1968) ${ }^{8}$ citado por Zylbersztajn (1995, p.118) define que "um CSA engloba todos os atores envolvidos com a produção, processamento e distribuição de um produto. Tal sistema inclui o mercado de insumos agrícolas, a produção agrícola, operações de estocagem, processamento, atacado e varejo, demarcando um fluxo que vai dos insumos até o consumidor final. O conceito engloba todas as instituições que afetam a coordenação dos estágios sucessivos do fluxo de produtos, tais como as instituições governamentais, mercados futuros e associações de comércio".

É apresentado, também, o conceito de cadeia (filière) agroalimentar. Filière surgiu da escola de economia industrial francesa e corresponde à seqüência de atividades que transformam uma commodity em um produto final pronto para o consumo. Foi um conceito desenvolvido na década de 60 e que mais se aproxima das cadeias produtivas citadas anteriormente (Pires, 2004).

Os dois modelos (CSA e filière) tentam explicar a necessidade de coordenação, quer seja via mercado ou via integração vertical no agronegócio, mas não expõem qual o grau de integração (completa, parcial ou simples) nem um substituto para tal. É possível dizer, nos moldes atuais, que ambas são visões da gestão da cadeia de suprimentos aplicada à cadeia agroalimentar.

Portanto, CSA, filière e gestão da cadeia de suprimentos estão relacionadas ao mesmo assunto, mas com focos distintos no que tange aos planejamentos estratégicos e operacionais das empresas envolvidas no processo. Nesta seção da revisão de

\footnotetext{
${ }^{8}$ GOLDBERG, R.A. Agribusiness coordination: a systems approach to the weat, soybean, and Florida orange economies. Boston: Harvard University, Graduate School of Business and Administration, Division of Research, 1968. 256p.
} 
literatura, busca-se resgatar o que é pertinente ao presente trabalho e que já foi estudado para o caso do agronegócio via CSA e filière.

Neves et al. (2000) definem o ambiente do agronegócio como uma cadeia de suprimentos envolvendo diversas empresas do ramo de alimentos e agronegócios. A Figura 9 mostra esquematicamente o fluxo do produto entre os componentes da cadeia.

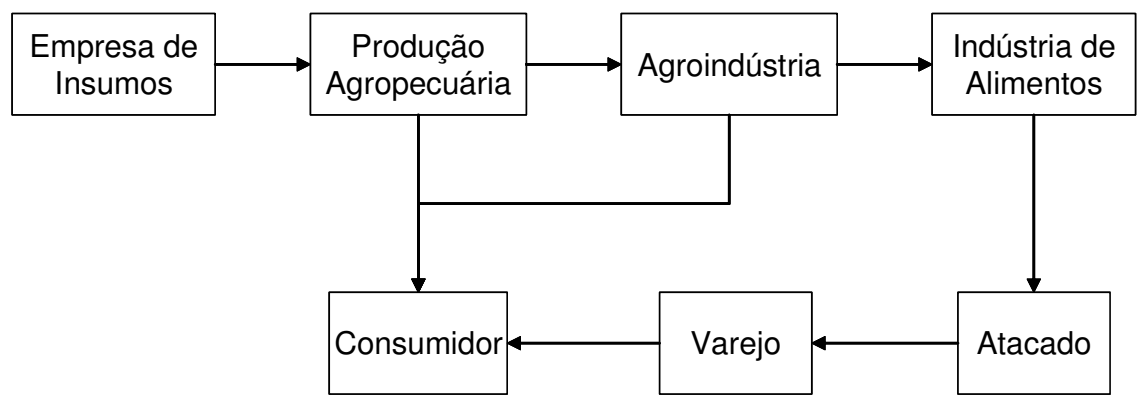

Figura 9 - O ambiente do agronegócio

Fonte: adaptado de Neves et al. (2000)

Os fornecedores são classificados em níveis de acordo com a "distância" em que se encontram da indústria produtora. Esta "distância" é representada pelo número de elos na cadeia a partir do elo central da indústria de alimentos.

Para o ambiente do agronegócio, as empresas de insumos são as fornecedoras de nível 3 para a indústria de alimentos, mas são as primeiras fornecedoras da cadeia. Elas podem ser tanto de insumos diretos para a produção, envolvendo fertilizantes, adubos, sementes etc. como indiretos, abrangendo máquinas e equipamentos. Tais insumos serão utilizados na produção agropecuária responsável pela produção propriamente dita.

A agroindústria é conhecida como a parte do negócio, ou da cadeia, responsável pelo que vem "depois das porteiras das fazendas", podendo preparar o produto para consumo final ou para a etapa de industrialização. 
As indústrias de alimentos são as transformadoras e processadoras dos produtos. Via de regra, elas agregam valor ao produto e industrializam o alimento antes de encaminhá-lo aos canais de distribuição.

Atacado, varejo e consumidor são os responsáveis pela distribuição dos produtos, sendo que não há mais transformação, apenas agregação de valor por serviço e participação dos canais de distribuição. De fato, ao se comparar o desenho da cadeia proposto por Neves et al. (2000) com a de Chopra \& Meindl (2003) e Bowersox \& Closs (2001) utilizada para o desenvolvimento deste trabalho, percebe-se uma adaptação coerente dos elos da cadeia de suprimentos propostos.

Da cadeia desenhada na Figura 9, há um elo muito forte que interage com a agroindústria: a indústria de alimentos. Muito trabalhado no meio acadêmico, este elo merece uma análise particular, pois é o que agrega mais valor ao produto e movimenta grandes quantias financeiras. Une-se a isto a importância de ser o elo central da cadeia, por possuir o status do conjunto das empresas.

Outro fator é a saturação do mercado de alimentos em países desenvolvidos, obrigando a briga por preços, qualidade e serviços diferenciados. Esse mercado é caracterizado por uma situação peculiar onde há tendência de excesso de oferta e pela difusão de uma preocupação excessiva com a qualidade e a segurança dos alimentos (Green \& Schaller, 2000). Diversos estudos acadêmicos, projetos empresariais e governamentais sobre segurança alimentar confirmam tais características.

Neves (1999) acrescenta que, no aspecto distribuição, as técnicas de JIT estão sendo trabalhadas para seu sucesso ao buscar a garantia de suprimento, conformidade no atendimento (também conhecida como nível de serviço), qualidade do produto e apropriação de margem superior no sistema. Acrescenta a isto as práticas já citadas do ECR, as quais são aplicadas essencialmente entre os elos "indústria de alimentos", "atacado", "varejo" e "cliente final".

Green \& Schaller (2000) e Neves (1999) discutem as tendências na cadeia de suprimentos da agroindústria, com foco em alimentos, sob os mesmos aspectos: a 
racionalização dos sistemas logísticos na busca de competitividade e a redução de custos para conquista de mercados.

A adequação da cadeia toda com foco nos consumidores finais (visão "para

frente") e gerenciamento dos recursos produtivos integrados (visão "para trás") explica a necessidade de integração da cadeia e planejamentos integrados visando às otimizações de estoques, níveis de serviço altos e resposta rápida. É coerente dizer que se o consumidor não encontrar o alimento para comprar na primeira tentativa, o concorrente ganha a venda.

Um exemplo é a água mineral. O comprador não espera a chegada da água que ele pretendia adquirir para sanar a sua sede. Se não encontrar, a primeira que estiver mais próxima ganhará a venda. É o fator velocidade de resposta às necessidades do mercado e a disponibilidade como ganhador de pedidos. Em uma primeira análise, tratase de canais de distribuição responsivos, mas com uma certa migração para cadeia eficiente.

No decorrer da análise de gestão da cadeia de suprimentos e do ambiente do agronegócio, percebeu-se que neste ramo há uma forte tendência para a integração vertical. Tal modelo de governança merece análise um pouco mais aprofundada, justificada também pela cadeia do frango, que segue o mesmo modelo.

Alia-se a isso o aspecto destacado por Pires (2004) acerca da competição entre as cadeias de suprimentos confirma a necessidade do alinhamento estratégico para gerenciar cadeias de forma integrada. A carência em diversas cadeias é suprimida em práticas inerentes à tradicional governança via integração vertical como benchmark empresarial.

\subsection{Estruturas de governança}

Esta seção não tem como objetivo resgatar os conceitos oriundos de todas as formas de estrutura de governança, mas relacionar o que há na teoria envolvida que 
auxilie na explicação de coordenação vertical, de integração vertical e da gestão da cadeia de suprimentos, estrutura principal deste trabalho.

Cabe aqui salientar que há uma certa diferença entre parcerias e governança. Pires (2004) define que parceria é um tipo de relacionamento entre empresas independentes como se fosse uma unidade de negócio virtual, mas com elevado nível de colaboração. Está mais relacionada à estratégia do desenvolvimento das atividades, fatores-chave da cadeia de suprimentos e à administração empresarial.

Já governança está mais ligada à maneira como é conduzida a coordenação das atividades econômicas e dos sistemas produtivos. Zylbersztajn (1995) a define como uma estrutura-padrão de transações e contratos que minimizem custos de transação, como unidade analítica, dentro de organizações.

Jank (1996, p.16) defende que governança é "a forma organizacional utilizada para organizar a produção, sendo que há basicamente três formas ou estruturas alternativas: mercado clássico, contratos híbridos e hierarquia (integração vertical)”. Zylbersztajn (1995) também faz essa divisão.

Portanto, essas possíveis estruturas são analisadas em relacionamentos entre empresas do que diversos estudiosos de estratégia chamam de fazer versus comprar (do inglês, make-or-buy). A abordagem da integração vertical é bem difundida, mas para uma compreensão mais bem alicerçada, resgatar-se-á alguns conceitos sobre Economia dos Custos de Transação (ECT) que será discutida na seção seguinte.

Mesmo que a integração vertical seja um fator exógeno à discussão deste trabalho, a seção 2.2.2 discutirá as vantagens, desvantagens e fatores a considerar em decisões sobre integração vertical. Estas explicações serão os fundamentos para o entendimento da cadeia de frango no Brasil. 


\subsubsection{Economia dos custos de transação 9}

A presente seção abordará os conceitos oriundos das estratégias de governança, com foco na integração vertical. A primeira discussão-chave a ser analisada é a identificação de momentos oportunos para uma empresa (ou a cadeia de suprimentos) decidir pela integração vertical de uma atividade ou de elos. Assim, as vantagens, as desvantagens e os fatores a considerar serão discutidos ao longo do texto a fim de serem esclarecidos pontos na tomada de decisão.

A segunda discussão-chave a ser analisada está em como trabalhar os custos dificilmente mensuráveis, os chamados custos de transação, os quais serão utilizados na análise do estudo de caso. A ECT deve ajudar a discutir os referidos problemas.

Ao se abordar o assunto de integração vertical, primeiramente é necessário mostrar sucintamente um escopo da chamada Nova Economia Institucional (NEI), além de definir como as decisões sobre integração são abordadas segundo as teorias levantadas.

Coase (1937), continuamente citado por diversos autores, trouxe a abertura teórica sobre a NEI, considerada uma das mais importantes contribuições para os estudos posteriores. Dele evoluíram os principais conceitos da ECT, reconhecendo a existência dos custos no ambiente econômico empresarial.

Segundo Furubotn \& Richter $(1991)^{10}$, citados por Zylbersztajn (1995), custos de transação são necessários para se colocar o mecanismo econômico e social em funcionamento. Eles não são originários diretamente da produção, mas surgem quando os agentes se relacionam entre si e os problemas de coordenação das ações emergem.

Na mesma linha de raciocínio, North (1994), citado por Zylbersztajn (1995) e Hanashiro (2003), define custos de transação como custos inerentes às operações econômicas desenvolvidas por atores que não produzem o que os indivíduos consumirão

9 Esta seção foi embasada essencialmente no trabalho de Zylbersztajn (1995)

${ }^{10}$ FURUBOTN, E.; RICHTER, R. The new institutional economics: an assessment. College Station: Texas A\&M Press, 1991. 
(por exemplo, serviços de advogados, de contadores e atuações políticas), mas que são necessários para o funcionamento, a sustentabilidade e o sucesso do negócio.

Bianchini et al. (2003) citam que três são as categorias relevantes dos custos de transação: os de informação e procura, os de decisão e barganha e os de controle e execução.

Hanashiro (2003) comenta que as instituições atuam na regra do jogo em uma sociedade e representam os limites do homem para disciplinar as interações humanas. Neste caso, as firmas são vistas como um conjunto de contratos que disciplinam transações, definidas como as transformações de um produto por meio de interfaces tecnologicamente separáveis.

Ao mesmo tempo, os custos de transação são abordados como custos comparativos para tomadas de decisões entre estruturas de governança existentes. Saem as empresas como foco principal e entram as abordagens dos contratos, uma vez que a visão da NEI é de que empresas são conjuntos de contratos, aplicando-se, assim, as três categorias de custos de transação.

Zylbersztajn (1995, p.23) apresenta um esquema de indução das formas de governança segundo alguns critérios macros de análise, cujo resultado final será a forma que minimiza os custos de transação. A Figura 10 mostra o esquema inter-relacionado. 


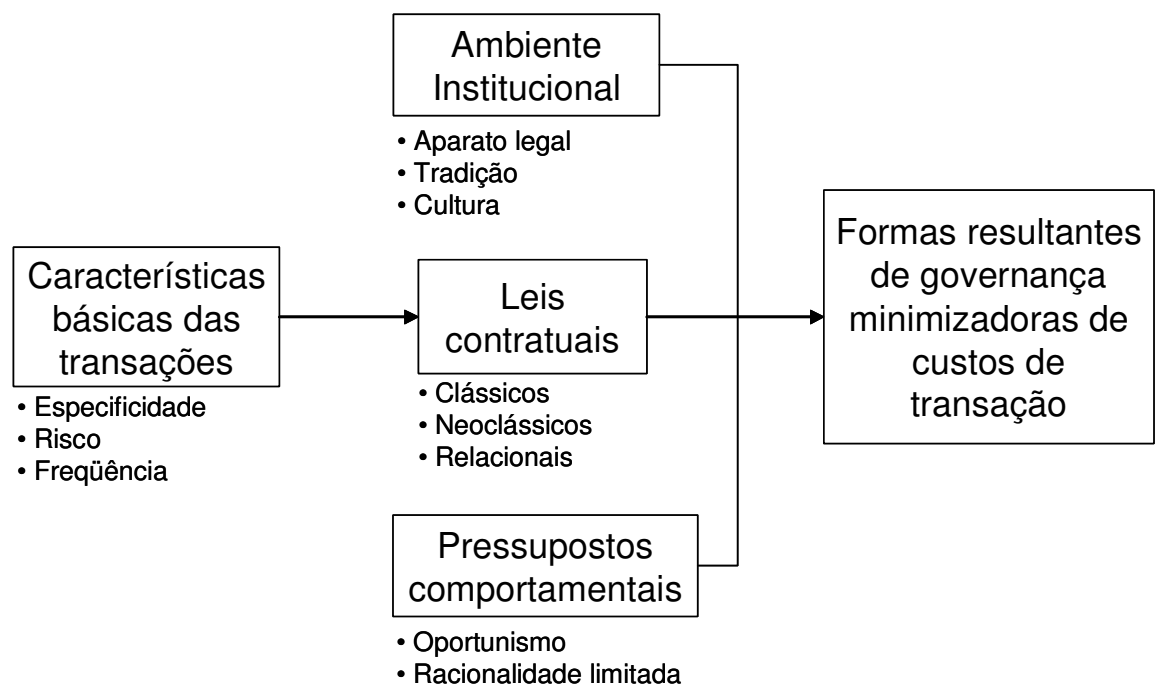

Figura 10 - Esquema de indução das formas de governança

Fonte: adaptado de Zylbersztajn (1995, p.23)

Esse esquema considera quatro análises principais, sendo: i) as características básicas das transações; ii) o ambiente institucional em que a empresa está inserida; iii) quais as leis contratuais vigentes segundo modelos econômicos de contratos; e iv) pressupostos comportamentais.

Segundo o pesquisador, o modo eficiente de governança resultará da interação entre o ambiente institucional e o comportamento dos indivíduos que minimizem os custos de transação.

Ainda segundo Zylbersztajn (1995), o pressuposto básico da ECT é de que existem custos na utilização do sistema de preços bem como na condução de contratos intrafirma. Portanto, para o funcionamento do sistema econômico, não apenas os contratos efetuados via mercado são importantes, mas também aqueles coordenados centralmente pelas firmas.

Os fatores principais a serem analisados por essa teoria são: atributos das transações (freqüência, incerteza ou risco e especificidade dos ativos), comportamento oportunista dos agentes econômicos (o que traz a necessidade de contratos mais 
detalhados e monitoramento das atividades do dia-a-dia), custos de produção, informações assimétricas (que geram oportunismos) e racionalidade limitada (nem tudo é previsível).

O ambiente institucional será ditado pelo aparato legal vigente, assim como a tradição e a cultura no desenvolvimento das relações entre organizações. As leis contratuais sugerem teorias econômicas sob o ponto de vista clássico e neoclássico. Este ponto não será detalhado no trabalho.

Williamson (1985) destaca que os custos de transação podem ser divididos em ex-ante e ex-post. Os custos ex-ante são aqueles responsáveis pelo processo de negociação, informação, realização de contratos e acordos, ou seja, antes do fechamento de qualquer negociação.

Os ex-post surgem dos conflitos ou desvios causados durante o processo ou após a realização da transação, não contemplados nos contratos iniciais, ou seja, após a realização do negócio. Todos são necessários para a condução de qualquer sistema econômico produtivo.

A especificidade dos ativos merece destaque segundo Williamson (1985), pois é um dos fatores principais da decisão da integração vertical de uma empresa. Ela diz respeito ao quanto o ativo consegue ser redirecionado para desenvolver outro tipo de atividade antes realizada. Isto significa dizer que quanto mais específico for o ativo, maior a dificuldade de adaptação para realizar outra atividade sem que haja necessidade de investimentos ou prejuízos no processo.

Além disso, atividades oportunistas encontram mais espaço para surgirem, apontando maiores custos dos contratos em relação ao custo da integração (Zylbersztajn, 1995 apud. Klein, Crawford \& Alchian, 1978).

Exemplos típicos podem ser observados em diversas cadeias produtivas agrícolas, como as colheitadeiras de cana, que não podem ser facilmente adaptadas para colherem outro produto, ou um galpão para criação de pintos, que não pode ser usado para criação de porcos. 
Nesse âmbito, quanto maior a especificidade dos ativos e a freqüência de seu uso, mais a integração vertical ganha espaço, pois traz a necessidade de relações duradouras entre os agentes nesse contexto, a fim de se explorar ao máximo o seu potencial (Hanashiro, 2003).

Pode ser difícil encontrar no mercado um agente que se disponha a investir em ativos específicos ou, caso haja, a necessidade contratual pode inviabilizar a negociação. Tais conceitos serão discutidos com foco na cadeia de suprimentos integrada verticalmente na seção seguinte.

No âmbito da gestão da cadeia de suprimentos, Neves (1999) discute que a ECT ajuda a responder questões como por que, em certas regiões, negócios semelhantes ou empresas semelhantes utilizam contratos diferentes ou por que escolher um tipo de contrato em detrimento de outro, em trabalho focado para canais de marketing e distribuição.

Ainda que diversos autores sinalizem para a dificuldade de se transformar os custos de transação em algo mensurável em termos contábeis, a ECT pode fornecer análises ou direcionadores para o modelo proposto neste trabalho de custos para cadeia de suprimentos.

Portanto, tal teoria pode ser considerada como adequada para explicar o movimento já realizado, segundo interesses empresariais durante os processos de mudança, assim como para mensurar quantitativamente o que foi estabelecido (Nogueira \& Zylbersztajn, 2003).

A busca pela sinergia entre os elos e a minimização de custos de transação sinalizam para a estrutura de governança que melhor se adapta a uma certa cadeia. A maior parte das pesquisas encontradas foi na tentativa de responder se um ativo é específico a ponto de merecer sua integração.

Em princípio, a integração sempre será muito bem aceita se o potencial de aumento de lucro (ou até redução de custos) for percebido na organização. 
Num escopo do grau de comprometimento com uma outra organização versus a formalização do relacionamento, Grant (2002) esquematiza os diversos tipos de estruturas em uma cadeia de suprimentos. A Figura 11 contempla estas possíveis estruturas de governança.

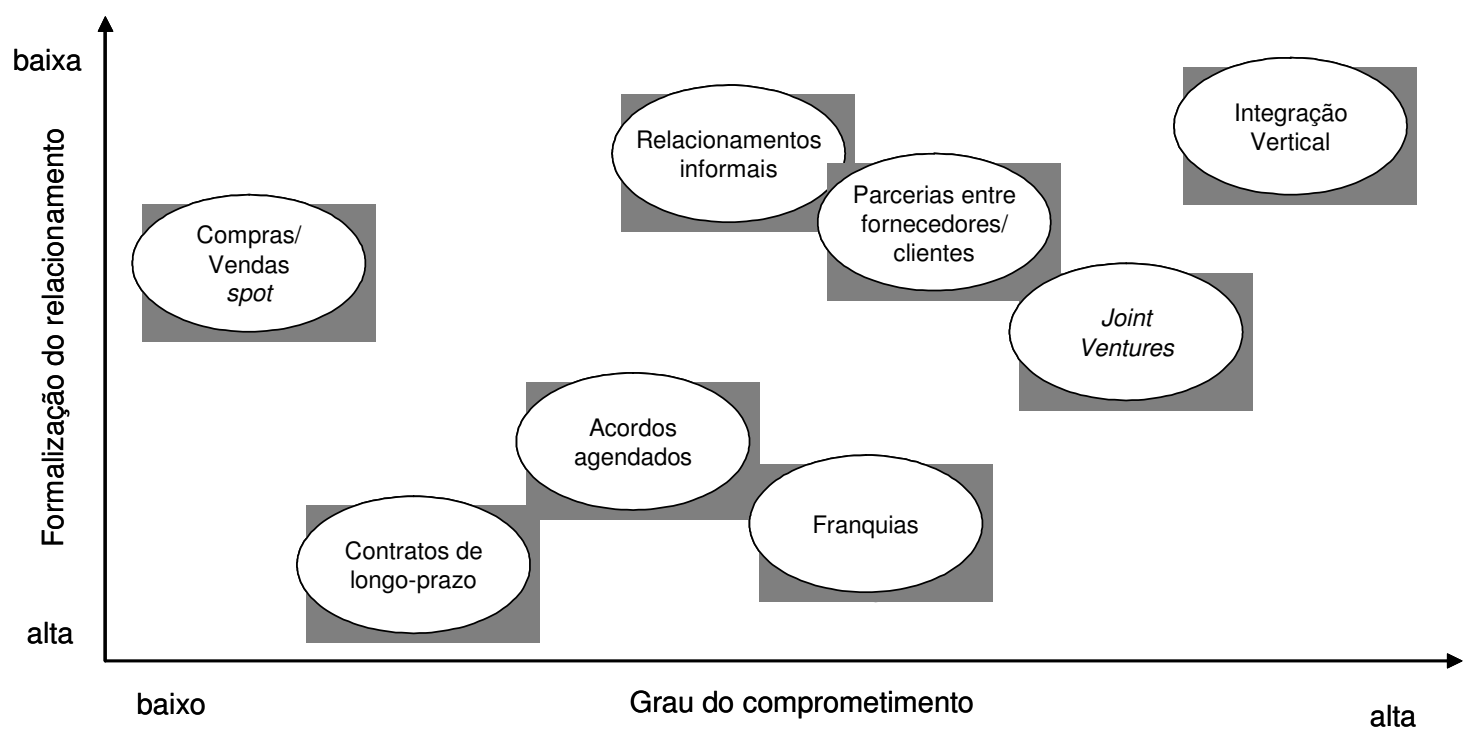

Figura 11 - Estruturas de governança na cadeia de suprimentos Fonte: adaptado de Grant (2002, p.401)

Em termos de decisão de governança das transações, Zimmerman et al. (1997) indicam uma correlação entre a especificidade dos ativos e a incerteza nas negociações e previsões futuras. O Quadro 4 contempla esta correlação. 
produção da borracha até a finalização da montagem do automóvel, tudo estava sob o domínio da Ford Company.

De fato, naquela época, a oferta de fornecedores era escassa e mesmo a qualidade e conformidade dos produtos ofertados inviabilizava as compras. A solução para aquele momento era utilizar-se da produção in-loco ou integrada verticalmente para suprir uma demanda crescente pelos seus veículos (Womack et al., 2004).

Womack et al. (2004) discutiram que a questão era substituir a "mão invisível" do mercado pela "mão visível" da coordenação organizacional, em alusão ao trabalho de Adam Smith. Acreditava-se, também, que a integração vertical interferia sobre as forças do livre mercado e as operações se tornariam mais previsíveis.

Com o passar do tempo, o próprio Ford percebeu que a complexidade do sistema impossibilitava as sinergias necessárias e a gestão integrada. A quase total verticalização trouxe consigo uma burocracia não prevista a ponto de surgirem problemas sem soluções visíveis naquela época. Seria o aumento significativo dos custos de transação refletindo o desempenho da empresa.

Ainda assim, a integração vertical sempre foi muito difundida e aplicada no sistema de produção em massa muito protagonizado pelo Ford, típico sistema de produção empurrado. Já o sistema de produção puxado desenvolvido mais tarde pela Toyota, no Japão, evita semelhante tratamento e trabalha mais focado em parcerias.

Começou-se, dessa forma, a desenvolver estudos relacionados com o makeor-buy das organizações no âmbito estratégico. Não é de se surpreender que o make perdeu espaço para o buy com o passar do tempo.

Atualmente, a prática da terceirização de tarefas tornou-se chave para qualquer organização e qualquer movimento de descentralização gerencial tende a buscar o que era de melhor no desenvolvimento das atividades antes sob domínio vertical.

Existe uma certa diferença entre a integração horizontal (ou horizontalização) e a vertical. A primeira é realizada entre empresas que atuam no 
mesmo âmbito hierárquico da cadeia. Normalmente são concorrentes diretas, trabalham na exploração de nichos de mercado num mesmo segmento e buscam rápidas economias de escala (Dyer et al., 2004).

Já integração vertical é um conceito bastante genérico, que pode ser caracterizado como a combinação de diversos processos tecnologicamente distintos como produção, processamento, distribuição e vendas dentro das fronteiras de uma mesma empresa. Isto significa estar sob um mesmo comando decisório (seja um indivíduo, empresa, conglomerado, instituição ou outra forma) e envolvendo a propriedade total ou até parcial dos ativos das mesmas (Williamson, 1985; Coughlan et al., 2002).

As explicações para a integração vertical podem ser divididas em dois grandes grupos: os que a consideram como obtenção de poder de monopólio e os que a encaram como estratégia de minimização de custos de transação gerando, então, mais eficiência. Zylbersztajn (1995), citando Williansom (1985), prefere se alinhar com este segundo grupo e que será também adotado no presente trabalho.

De acordo com Zylbersztajn (1995), as variáveis que induzem a integração vertical, com olhos na ECT, são analisadas segundo a necessidade de minimização de custos de transação e produção. No mesmo escopo, o grau de integração vertical será resultado das transações existentes por meio da especificidade dos ativos, freqüência de negociação, riscos e oportunismo.

Porter (1997) afirma que a integração vertical é a combinação de processos de produção, distribuição, vendas e/ou outros processos econômicos tecnologicamente distintos dentro das fronteiras de uma mesma empresa. Isto representa, portanto, uma decisão da companhia no sentido de utilizar transações internas ou administrativas em vez de optar por transações de mercado para atingir seus próprios objetivos econômicos.

Para Grant (2002), integração vertical refere-se à propriedade de empresas com atividades relacionadas verticalmente. Quanto maior a propriedade da empresa e 
controle sobre estágios sucessivos da cadeia de valor para o seu produto, maior é o seu grau de integração vertical, caracterizando a verticalização.

A integração vertical pode ocorrer em duas direções: para trás, onde a firma controla a matéria-prima, a produção de suas entradas (inputs) e assegura o fluxo de tempo e qualidade; e para frente, onde a empresa se aproxima dos seus clientes, possibilita organizar melhor a produção e controla seus fluxos de distribuição (Grant, 2002 e Marques, 1991). Ainda de acordo com Grant (2002), a integração vertical pode ser total ou parcial (parte dos elos de uma cadeia).

Marques (1991, p.39) define que integração vertical "ocorre quando duas ou mais firmas colocadas sob a mesma organização atuam em estágios separados do mesmo processo produtivo."

De acordo com Neves (1999), a integração é uma decisão da empresa por utilizar transações internas em detrimento de transações de mercado ou mistas. Pode ser mais barato, mais fácil e menos arriscado desenvolver atividades administrativas, produtivas, de distribuição ou marketing internamente do que recorrer ao mercado.

Apesar da afirmação, a análise não deve ser feita isoladamente, uma vez que torna necessária a análise dos custos de transação que serão incorporados ao sistema antes da decisão de se integrar verticalmente. Portanto, a sua eliminação não é iminente.

Dos conceitos apresentados sobre integração vertical, verifica-se que alguns autores (Grant, 2002; Coughlan et al., 2002; Stern et al., 1996; e Besanko et al., 2000) citam graus de integração vertical, tanto em posse dos ativos como em recebimento de ordens.

A caracterização de uma integração quase vertical citada por Coughlan et al. (2002) ou integração fraca (soft) por Stern et al. (1996) implica o uso dos conceitos do domínio pela integração vertical, mas a posse dos ativos é terceirizada.

Grant (2002) e Besanko et al. (2000) chamam esse relacionamento de coordenação vertical, cujo controle sobre os ativos e as operações de uma empresa é 
realizada por outra, mas a posse dos ativos é terceirizada, sob contratos habitualmente de exclusividade.

Zylberstajn (1995) comenta que a coordenação vertical é uma estrutura de governança empresarial desenvolvida de forma vertical, ou seja, sob diversos estágios da cadeia de produção, que pode ser realizada via contratos ou integração vertical completa. Assim, integração vertical é entendida como a coordenação de todas as etapas de produção, possuidora dos ativos de produção.

Por outro lado, entende-se como coordenação vertical o controle de todas as etapas de produção, mas por algum momento a empresa não é possuidora dos ativos de produção, surgindo a ação de contratos entre alguns agentes. Esta também é conhecida como integração vertical soft (ou parcial) ou integração quase-vertical. A aplicação desta definição é bem adaptada ao caso da cadeia do frango, como será visto na seção 3.1.

O encaminhamento do trabalho segue as análises da integração vertical, classificando a coordenação vertical como uma divisão daquela.

A Figura 12 ilustra de forma sucinta alguns dos principais aspectos envolvidos nesse tipo de análise.

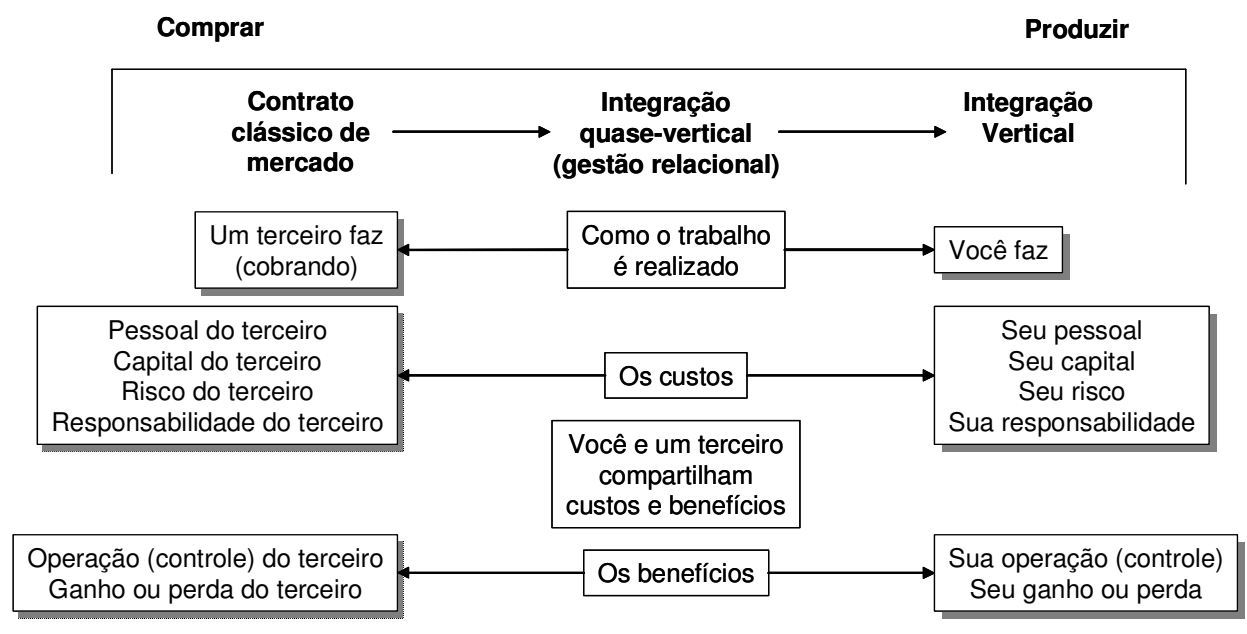

Figura 12 - Comprar ou produzir: uma análise simplificada do grau de integração Fonte: Coughlan et al. (2002) 
A integração vertical implica maiores margens sobre a organização de mercado à medida que aumenta a necessidade de ativos mais específicos. Dado seu poder de "faça-se" (coordenação e/ou produção interna), os custos de adaptação declinam conforme as mudanças são implementadas sob alta especificidade de ativos.

Contudo, da mesma forma como a solução integrada é melhor que o mercado em termos de adaptabilidade às mudanças, existe a desvantagem de adicionar custos burocráticos, além de redução ou perda dos fortes incentivos providos pelos mercados (Zylbersztajn, 1995).

Grant (2002) expõe que, numa firma integrada, os relacionamentos entre as unidades verticais, produtos e mercado são administrativos. Já no caso de especialização entre as empresas, cada unidade é uma firma gerenciada separadamente que se une a outras por relacionamentos de mercado. A Figura 13 mostra a visão dos três escopos (vertical, produto e geográfico) discutidos na página 30, segundo uma empresa integrada verticalmente e especializada em seu core business.

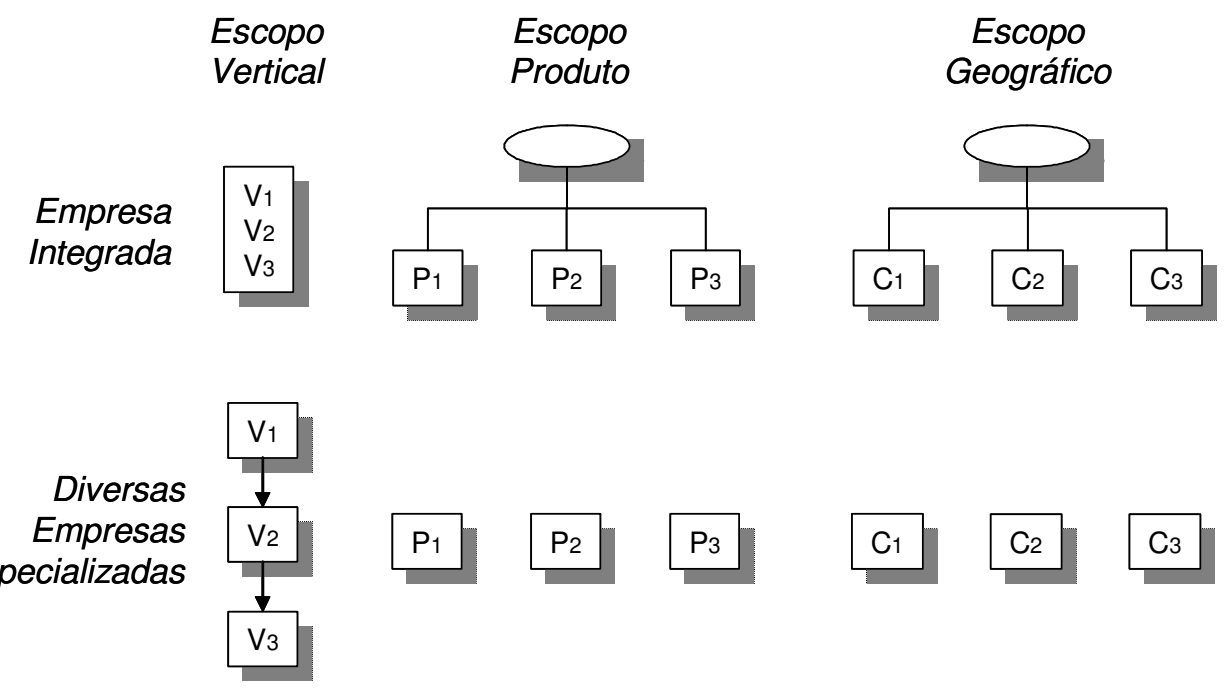

Figura 13 - O escopo da empresa: especialização versus integração Fonte: adaptado de Grant (2002)

Na Figura 13, Vi são as diferentes unidades verticais, $P i$ os produtos e $C i$ as diferentes unidades não verticais. No caso da firma integrada há relacionamentos 
administrativos entre os três escopos, possibilitando a figura de uma empresa centralizadora. Já na especialização, o relacionamento se dá via mercado.

Via de regra, a integração ocorre quando há expectativa de geração de lucros maiores. Um fator vantajoso e que pode trazer benefícios é a redução dos custos de transação (Williamson, 1985; Stern et al., 1996; Porter, 1997; Neves, 1999; e Grant, 2002). Entretanto, deve ser analisado com cuidado, uma vez que a integração vertical reduz em diversas vezes o custo de transação, mas aumenta o custo operacional com a sua internalização. O trade-off deve ser analisado antecipadamente.

Besanko et al. (2000) e Grant (2002) enfatizam a análise ao citarem que a integração vertical é muito favorável quando os custos administrativos internos são menores que os custos de transação. Este último é considerado um dos fatores-chave de decisão na maior parte dos casos.

O segundo fator-chave importante é o controle de alguns segmentos ou atividades desenvolvidas por elos na cadeia e que são estratégicos para o desenvolvimento empresarial, não apenas pelo lado do lucro, mas pela necessidade de sobrevivência do negócio.

Diversas vantagens são analisadas na integração vertical. Porter (1997) cita os relacionamentos estáveis entre as empresas (ou os elos), atenuando assim o possível oportunismo e a barganha durante negociações. Facilitam operações combinadas, coordenação e controle internos, assim como a troca de informações, o que garante oferta e demanda de forma balanceada (Williamson, 1985; Stern et al., 1996; Porter, 1997).

Como desvantagens, o primeiro fator é a necessidade de capital para aquisição, criação e manutenção dos elos, necessidade de alavancagem operacional que pode ser decisiva. Os custos dos investimentos são altos e devem ser analisados minuciosamente antes de qualquer decisão que possa impactar financeiramente toda a cadeia (Porter, 1997). 
A especificidade dos ativos complementa a questão dos investimentos, uma vez que a necessidade de mudanças ou adaptações tecnológicas demanda recursos financeiros que por vezes pode inviabilizar o que já se possui e o que se pretende ter.

Outro fator é a reduzida flexibilidade para mudança de parceiros se estes estão em fase de obsolescência, custos elevados de manutenção ou se há no mercado concorrentes melhores e mais eficientes.

Qualquer movimento de saída enfrentará elevadas barreiras financeiras e possivelmente psicológicas, que impactam diretamente na cadeia (Porter, 1997; Besanko et al., 2000). O próprio "fechamento" das empresas para o mercado tende a perder o acesso ao que há de ponta e uma forte tendência para baixas mudanças, pesquisas e evoluções.

A questão da integração dos elos, tanto para frente quanto para trás, pode levar a organização a uma acomodação natural, uma vez que a busca pelo ótimo devido à competição não mais é um fator de pressão (Porter, 1997; Besanko et al., 2000; Grant, 2002).

Os clientes e as vendas também são certos, o que diminui os esforços e tendencia às cobranças de metas e resultados menos necessárias. É mais difícil gerar e maximizar a eficiência em organizações integradas (Besanko et al., 2000), pois abaixa a capacidade de desenvolvimento e exploração de competências distintas em atividades verticalmente adjacentes. Além disto, diferenças substanciais nos negócios dificultam a sinergia administrativa, principalmente devido às distinções das culturas organizacionais envolvidas (Dyer et al., 2004).

Williamson (1985), Stern et al. (1996) e Womack et al. (2004) são enfáticos em considerar que o quesito informação é uma faca de dois gumes. O que antes era tratado como vantagem, pode se tornar uma desvantagem muito maior pelo efeito multiplicador gerado.

A informação, se bem trabalhada e coordenada, é extremamente benéfica e lucrativa. Entretanto, a sua má utilização ou a falta de alinhamento entre os elos gera 
ineficiências em praticamente todos, tornando-os pouco lucrativos de uma só vez. O impacto negativo é um efeito em cascata que pode arruinar toda a cadeia integrada.

De uma forma geral, a integração vertical deve ser muito bem estudada antes de qualquer decisão da cadeia. O que se busca é a possibilidade de explorar as vantagens trazidas pela integração vertical sem que as suas desvantagens se tornem latentes.

Por diversas vezes, uma empresa percebe que uma atividade não "chave" anteriormente torna-se crítica com o passar do tempo, sob o ponto de vista estratégico, trazendo questionamentos sobre a sua incorporação de alguma forma.

Não apenas o fator custo deve ser analisado, mas toda a gama de problemas gerenciais que a incorporação pode trazer ao longo do tempo. Portanto, a combinação de tarefas realizadas internamente (insourcing) com as realizadas externamente por terceiros, conhecidas como terceirização (outsoucing), são necessárias em qualquer cadeia hoje em dia.

O Quadro 5 faz um resumo respectivamente dos fatores a serem abordados com foco nas vantagens e desvantagens da prática de integração vertical pelas organizações, discutidos pelos principais autores citados ao longo do texto. 


\begin{tabular}{|c|c|c|}
\hline Autor & Vantagens apontadas & Desvantagens apontadas \\
\hline $\begin{array}{l}\text { Williamson } \\
(1985)\end{array}$ & $\begin{array}{l}\text { 1. economia sobre a racionalidade } \\
\text { limitada; } \\
\text { 2. atenua oportunismo nas negociações; } \\
\text { 3. reduz as incertezas ao promover } \\
\text { expectativas convergentes; } \\
\text { 4. domínio sob informações estratégicas } \\
\text { e operacionais; } \\
\text { 5. geração de atmosfera de maior } \\
\text { satisfação pela garantia do negócio por } \\
\text { alguns elos. }\end{array}$ & $\begin{array}{l}\text { 1. predisposição a favorecer manutenção } \\
\text { ou extensão de operações internas; } \\
\text { 2. controle político sobre decisões nos } \\
\text { elos; } \\
\text { 3. potencialização de oportunismo } \\
\text { interno (elo integrador); } \\
\text { 4. adicionamento de burocracia antes } \\
\text { fora da organização; } \\
\text { 5. perda de envolvimento moral; } \\
\text { 6. queda na política de incentivos. }\end{array}$ \\
\hline $\begin{array}{l}\text { Stern et al. } \\
(1996)\end{array}$ & $\begin{array}{l}\text { 1. garantia de suprimentos; } \\
\text { 2. racionalidade de níveis de estoques; } \\
\text { 3. ganho econômico em operações de: } \\
\text { a) interdependência tecnológica; } \\
\text { b) eliminação de prêmio de risco; } \\
\text { c) redução de custos de transação; } \\
\text { d) economia de escala; } \\
\text { e) relacionamentos estáveis; } \\
\text { 4. ganhos em informações rápidas; } \\
\text { 5. coordenação entre oferta e demanda; } \\
\text { 6. aumento das barreiras de entrada da } \\
\text { concorrência; } \\
\text { 7. diversificação dos negócios. }\end{array}$ & $\begin{array}{l}\text { 1. perda de economia com: } \\
\text { a) desbalanceamento de estágios de } \\
\text { operações integradas; } \\
\text { b) administração; } \\
\text { c) menores retornos; } \\
\text { 2. aumento de alavancagem operacional; } \\
\text { 3. barreiras para mobilidade; } \\
\text { 4. diferentes culturas organizacionais } \\
\text { podem causar conflito de interesses; } \\
\text { 5. clientes e/ou fornecedores podem } \\
\text { tornar concorrentes. }\end{array}$ \\
\hline Porter (1997) & $\begin{array}{l}\text { 1. possíveis maiores margens; } \\
\text { 2. redução dos custos de transação; } \\
\text { 3. relacionamentos estáveis entre } \\
\text { empresas; } \\
\text { 4. atenuação de oportunismos em } \\
\text { negociações com fornecedores ou } \\
\text { clientes; } \\
\text { 5. atenuação de barganhas; } \\
\text { 6. facilitação de operações combinadas; } \\
\text { 7. facilitação de coordenações e controles } \\
\text { internos; } \\
\text { 8. possibilidade de maior sinergia em } \\
\text { troca de informações (por } \\
\text { relacionamentos estáveis); } \\
\text { 9. balanceamento da oferta e demanda; } \\
\text { 10.elevado grau do emprego de } \\
\text { tecnologias específicas; } \\
\text { 11.aumento de barreiras de entrada e } \\
\text { mobilidade da concorrência. }\end{array}$ & $\begin{array}{l}\text { 1. elevada necessidade de capital para } \\
\text { aquisição; } \\
\text { 2. elevada necessidade de capital para } \\
\text { criação e manutenção; } \\
\text { 3. elevados custos de mobilidade; } \\
\text { 4. necessidade de alavancagem } \\
\text { operacional no caixa da empresa; } \\
\text { 5. ineficiência de um elo pode aumentar } \\
\text { o custo da cadeia; } \\
\text { 6. reduzida capacidade de mobilidade de } \\
\text { parceiros; } \\
\text { 7. necessidades administrativas } \\
\text { diferentes; } \\
\text { 8. acomodação em termos de inovações, } \\
\text { pesquisas, mudanças e evoluções. }\end{array}$ \\
\hline
\end{tabular}

Quadro 5 - Compilação dos fatores a considerar com foco nas vantagens e desvantagens apontadas da integração vertical 


\begin{tabular}{|c|c|c|}
\hline Autor & Vantagens apontadas & Desvantagens apontadas \\
\hline $\begin{array}{l}\text { Besanko et al. } \\
\text { (2000) }\end{array}$ & $\begin{array}{l}\text { 1. ganhos maiores se houver baixa } \\
\text { concorrência no mercado; } \\
\text { 2. possibilidade de economias de escala e } \\
\text { escopo na produção, quando houver } \\
\text { aumento dos custos de transação; } \\
\text { 3. possibilidade de ganhos se houver } \\
\text { necessidade de investimentos em } \\
\text { ativos extremamente específicos para a } \\
\text { produção; } \\
\text { 4. possibilidade de controle de atividades } \\
\text { ou elos estratégicos para a empresa; } \\
\text { 5. atenuação de barganhas entre elos. }\end{array}$ & $\begin{array}{l}\text { 1. acomodação por falta de cobrança de } \\
\text { desempenho e esforço de vendas; } \\
\text { 2. menos cobrança por desempenho } \\
\text { local; } \\
\text { 3. dependendo da escala de produção ou } \\
\text { freqüência de utilização do ativo } \\
\text { (contratos), o custo de transação pode } \\
\text { ser menor que o custo operacional; } \\
\text { 4. necessidade de investimentos em } \\
\text { relacionamentos entre elos. }\end{array}$ \\
\hline Grant (2002) & $\begin{array}{l}\text { 1. redução dos custos técnicos de } \\
\text { transação; } \\
\text { 2. economias de escala; } \\
\text { 3. redução de custos por oportunismos } \\
\text { entre elos; } \\
\text { 4. ambiente favorável ao alinhamento } \\
\text { estratégico na cadeia; } \\
\text { 5. ambiente favorável à colaboração } \\
\text { entre elos; } \\
\text { 6. facilitação em troca de informações e } \\
\text { planejamentos integrados. }\end{array}$ & $\begin{array}{l}\text { 1. aumento dos custos operacionais pela } \\
\text { internalização de elos ou operações; } \\
\text { 2. mais lentidão na busca da evolução do } \\
\text { segmento; } \\
\text { 3. elevada necessidade de investimentos; } \\
\text { 4. desbalanceamento de capacidades de } \\
\text { produção ou escalas de produção } \\
\text { pode aumentar o custo da integração; } \\
\text { 5. fuga do core business da empresa; } \\
\text { 6. problema de incentivos financeiros } \\
\text { internos, pela acomodação de vendas } \\
\text { e desempenho local; } \\
\text { 7. mais demora em aceitar melhorias ou } \\
\text { novas tecnologias (acomodação); } \\
\text { 8. queda na flexibilidade de troca de } \\
\text { fornecedores/clientes. }\end{array}$ \\
\hline $\begin{array}{l}\text { Coughlan et al. } \\
\text { (2002) }\end{array}$ & $\begin{array}{l}\text { 1. controle da operação integrada; } \\
\text { 2. possíveis aumentos de margem } \\
\text { operacional (retenção dos lucros); } \\
\text { 3. redução de barganhas pelos elos da } \\
\text { cadeia; } \\
\text { 4. aumento do controle decisório sobre } \\
\text { os elos; } \\
\text { 5. evitar riscos morais (possíveis } \\
\text { desacordos); } \\
\text { 6. evitar incertezas ambientais } \\
\text { (volatilidade do mercado). }\end{array}$ & $\begin{array}{l}\text { 1. aumento dos custos operacionais; } \\
\text { 2. internalização dos riscos } \\
\text { operacionais; } \\
\text { 3. desmotivação do elo (busca de } \\
\text { resultados pela aceitação do risco do } \\
\text { negócio); } \\
\text { 4. fuga do negócio central da empresa; } \\
\text { 5. perda de economias de escala (por se } \\
\text { utilizar menos de contratos externos). }\end{array}$ \\
\hline
\end{tabular}

Quadro 5 - Compilação dos fatores a considerar com foco nas vantagens e desvantagens apontadas da integração vertical

Fonte: Williamson (1985), Stern et al. (1996), Porter (1997), Neves (1999), Besanko et al. (2000), Grant (2002) e Coughlan et al. (2002) 
O capítulo seguinte descreve a cadeia de suprimentos do frango no Brasil. A sua importância para a economia nacional e o dimensionamento econômico serão abordados para que toda a teoria apresentada até o presente seja bem explorada e aplicada na análise e no estudo de caso do Capítulo 4. 


\section{A CADEIA DO FRANGO NO BRASIL}

Este capítulo abordará questões relacionadas à cadeia do frango no Brasil com foco no que foi levantado anteriormente, ou seja, na gestão da cadeia de suprimentos e na integração vertical. Trata-se das fases do entendimento do mercado e da cadeia de suprimentos para a realização de seu alinhamento estratégico, sugeridas por Chopra \& Meindl (2003).

Reforçando os conceitos já desenvolvidos, Canever et al. (1997) apontam que a sustentabilidade da competitividade da produção avícola nacional exige responsabilidade de todos os agentes da cadeia. Além disto, o popularmente falado "da granja ao garfo" busca os benefícios de custo e competitividade ao setor (AveseOvos, $2004)^{11}$.

\subsection{A indústria de aves no Brasil}

Trabalhos relacionados à estratégia empresarial e economia de empresas, desenvolvidos por Porter, Rummelt, Quinn, Slater, dentre outros, mostram que a natureza da competição na indústria é função direta das atividades de entrada de novas empresas concorrentes, novos produtos ou serviços oferecidos pela concorrência já atuante, do poder de barganha dos elos da cadeia (fornecedores e compradores) e do grau de rivalidade existente entre os competidores.

${ }^{11}$ SILVA, J.C.T. da. (Associação Paulista de Avicultura, São Paulo). Comunicação pessoal, 2004. 
Essas características, se aplicadas conjuntamente a um setor industrial, podem fornecer seu panorama. Entretanto, a evolução histórica de qualquer atividade industrial merece ser resgatada na tentativa de explicar e entender o seu presente.

A cadeia do frango passou por diversas mudanças estratégicas, segundo um processo iniciado no período pós-Segunda Guerra Mundial, fundamentado na década de 60, evoluído e consolidado nas décadas de 70 e 80 até chegar ao modelo atual de integração vertical.

Unem-se a isso movimentos geográficos de concentração devido a determinantes individuais das empresas. A atividade era desenvolvida de forma independente, sendo que granjeiros adquiriam insumos no mercado para engorda de suas aves e, na seqüência, vendiam aos frigoríficos para o abate.

O processo de integração da indústria avícola começou no Estado de Santa Catarina juntamente com o processo de diversificação dos frigoríficos de suínos, segundo o modelo de estrutura de governança já vigente nos EUA desde as décadas de 50 e 60.

Canever et al. (1997) mostram que a concentração geográfica das empresas avícolas ocorreu devido ao fortalecimento mútuo trazido pela proximidade, influindo diretamente na melhoria das técnicas de manejo e inovações do processo produtivo, pois promovem eficiências e especializações na região de atuação.

Essa proximidade foi observada também nas décadas de 70 e 80, sendo que o fortalecimento da integração vertical, da coordenação vertical e da diversificação horizontal possibilitaram a consolidação de líderes de algumas empresas no mercado brasileiro.

Particularmente nesse período, empresas de grande porte passaram a ter a liderança do mercado, em detrimento das empresas de menor porte. Aliado a este fator, ocorreram as mudanças tecnológicas por meio do melhoramento genético, da alimentação adequada e otimizada, dos processos de produção automatizados e do uso de equipamentos adequados à produção flexível para produtos industrializados. Tudo 
isto trouxe progresso e competitividade mundial para a indústria avícola nacional, colocando-a na vanguarda do segmento de carnes (Rizzi, 1993).

Nos anos 90 houve a acomodação do movimento empresarial das duas décadas anteriores, estendendo-se até o momento. O modelo de integração vertical e de coordenação vertical com foco no custo de produção permitiram o sucesso dos fatores relacionados à estratégia empresarial e à economia descritas anteriormente.

As duas causas diretas principais para o pioneirismo do Sul do Brasil nesse movimento foram a oferta de grãos para a indústria de rações, principalmente as culturas de soja, milho e trigo, que se consolidaram como as principais atividades agrícolas da região e propiciaram o desenvolvimento de um pólo de atração de capitais.

Essas análises foram conduzidas por Canever et al. (1997) e Rizzi (1993) em seus respectivos trabalhos, atestando que o sistema de contratos de parceria integrada de produção mostrou sua eficiência, coordenando atividades de produção de insumos e serviços como fornecimento de pintos, ração, logística de transporte, mão-de-obra do produtor rural, assistência técnica para produção até a industrialização e distribuição do produto final, além da paralela evolução tecnológica verificada até os dias de hoje.

Em menos de duas décadas foi possível gerar economia de recursos e economia de escala, suplantando a produção existente principalmente no Estado de São Paulo, organizada de forma independente desde a década de 50 e que foi se reorganizar em contratos e também em integração vertical em tempos mais recentes.

Atualmente percebe-se uma movimentação das indústrias para o Norte e Centro-Oeste do País, principalmente Goiás, Bahia, Minas Gerais e Mato Grosso. Favaret-Filho (1998) discute o projeto de implementação de um sistema de integração na região de Rio Verde (Goiás) pela Perdigão com criticidade lógica, a fim de concluir quais critérios nortearam a escolha do local para implementação do projeto.

Sua conclusão principal aponta para a proximidade com as áreas fornecedoras de matérias-primas a baixo custo, especialmente o milho e a soja para ração, uma vez que somente o milho representa cerca de dois terços do volume e do 
custo das rações, além da necessidade de ampliação de novos integrados. Saboya (2001) confirma isto e acrescenta que tal movimento também foi devido às possibilidades de sinergia entres os elos à jusante da produção.

Essas novas localidades são caracterizadas por produtores com maior escala de produção, sendo que há configurações de propriedades maiores que as verificadas na região Sul do País.

Portanto, os determinantes fundamentais foram basicamente logísticos, ou melhor, estratégicos da cadeia de suprimentos integrada verticalmente, e possibilitou economias de escala para a agroindústria se instalar naquele local. Outro exemplo é a Sadia, atual líder de mercado nacional, que inaugura sua fábrica no sul do Estado de Minas Gerais, seguindo os mesmos princípios citados anteriormente.

De fato, percebe-se que os movimentos empresariais na agroindústria nacional, atualmente, seguem também a tendência dos movimentos espaciais da nova fronteira agrícola brasileira e dos novos corredores de transporte em desenvolvimento, tanto para escoamento da produção para o mercado interno quanto para o externo (Liderança, 2004).

Essa mesma análise havia sido apontada como tendência por Rizzi (1993), uma vez que a produção de soja e milho na região Sul e a mão-de-obra dos integrados já se encontravam próximas de seus esgotamentos.

Vale ressaltar que o termo "integrado(s)" é comumente utilizado no meio para se referir aos produtores que trabalham no processo de criação e engorda dos animais segundo um contrato de parceria exclusivo (coordenação vertical).

A estrutura do integrado merece atenção pela sua forma de atuar no mercado. Seu conceito é relativamente simples: trata-se normalmente de um pequeno produtor, dono de uma estrutura específica para o crescimento dos pintos (Taube-Netto, 1996). A empresa fornece a ele (ABEF, 2004):

- Construção e instalação de aviários e equipamentos;

- Treinamento de manejo; 
- Ração balanceada, baseada em milho (66\%) e soja (24\%);

- Acompanhamento veterinário;

- Entrega das aves para abate no prazo e peso necessários;

- Escalas de abate e tamanho das aves para diferentes mercados;

- Faturamento menos oscilante se comparado à venda direta no mercado.

A função do integrado é oferecer a infra-estrutura para criar o pinto, com investimento próprio, até o ponto do abate, decidido pela empresa. Esta oferece ao criador uma remuneração de acordo com negociações prévias e critérios de desempenho e eficiência, além de suprir grande parte das necessidades do negócio. Mesmo com o conceito simples, a empresa tem de lidar diariamente com problemas operacionais de grande complexidade e magnitude (Taube-Netto, 1996).

No Brasil, grande parte dos integrados é formada por famílias que vivem em suas próprias propriedades e criam também suínos dentro do mesmo sistema. Normalmente fecham contratos com apenas uma empresa e toda a sua produção (seja frango, seja suínos) segue um único destino.

O processo coordenado verticalmente assegura para a cadeia, segundo a ABEF (2004):

- Baixo custo de produção;

- Tecnologia, qualidade e inovação no processo produtivo, com rigoroso controle sanitário;

- Empresas com certificação internacional;

- Capacidade de adaptação em relação à demanda por produtores especiais pelo mercado comprador;

- Rastreabilidade de todo processo produtivo e de vida do frango até o envio ao mercado consumidor; 
- Garantias de sanidade e segurança alimentar necessárias para o mercado interno e externo devido ao rastreamento do processo.

Ainda segundo a ABEF (2004), o sistema coordenado verticalmente faz parte da vantagem competitiva nacional e é o responsável pelas conquistas brasileiras tanto no mercado interno quanto no externo. O modelo é sinérgico, conciliando eficiência produtiva com a grande capacidade de produção em escala e distribuição dos processadores de carne.

Além disso, o alto grau de tecnologia empregado traz eficiência para as modernas propriedades rurais, as quais são apontadas como propulsoras do agronegócio brasileiro (Liderança, 2004).

O contrato de parceria, segundo um modelo de coordenação vertical na cadeia produtiva das aves de cortes, sintetizam o diferencial de custos que viabilizaram e continuam viabilizando a sua aplicação.

As empresas integradoras da carne de frango conseguem terceirizar uma quantidade considerável de investimentos na cadeia, necessária para a criação das aves. O ativo imobilizado (as terras e a infra-estrutura necessárias) fica sob responsabilidade do integrado que assume este investimento.

Mesmo pelas vantagens apresentadas desse modelo, surgem os questionamentos em relação à baixa remuneração dos integrados pelos integradores. Entretanto, há quem diga que o risco desse agronegócio é assumido pelos integradores, que oferecem ao integrados uma renda fixa com menor risco, algo pouco vigente em mercados de commodities agrícolas (Marques, 1991; AveseOvos, 2004).

Todos os fatores mencionados garantem certo grau de flexibilidade para a indústria, maior que seus concorrentes mundiais, oferecendo rápidas adaptações às mudanças do mercado.

Aveseovos (2004) mostra que no Brasil já há integração vertical e coordenação vertical em torno de $75 \%$ na cadeia de produção do frango, reforçando o 
modelo bem-sucedido do setor. Este valor muda nas regiões brasileiras, com destaque para o Sul, que possui praticamente 100\%; Centro-Oeste, com 83\% (Saboya, 2001); e na outra ponta o Sudeste, com 33\% (Nogueira \& Zylbersztajn, 2003) para esta estrutura de governança.

Atualmente, devido à competição globalizada, os produtos nacionais devem ser também competitivos, sobretudo internamente, para depois poderem ser comercializados no Exterior. Esta visão é recíproca se olharmos os demais países. Logo, parte da competição interna é função da competitividade do setor no mercado externo.

A carne de frango é tida como uma commodity mundial, o que força a competição para redução significativa de custos ou diferenciação dos produtos. Como alimento, não foge das características de mercado saturado já citado anteriormente por Green \& Schaller (2000).

Os fatores de diferenciação e custos são fundamentais na análise da cadeia do frango, uma vez que o Brasil possui um dos menores custos de produção mundial e cujos produtos sofreram elevadas modificações para agregação de valor aos mercados, além da flexibilidade produtiva nas indústrias.

As margens de lucro verificadas no mercado são baixas, o que força a adoção de uma economia de escala na produção que gere renda o suficiente para sobrevivência no negócio ou diferenciação dos produtos, um dos motivos do sucesso das grandes empresas do ramo.

Portanto, sobrevivem aquelas que forem capazes de oferecer ao mundo o melhor produto ao menor custo, conseguindo gerenciar e sustentar os quesitos sobre competição na indústria.

Rizzi (1993) defende que a inovação e a diferenciação, trazendo agregação de valor ao produto alimentar, são fortemente guiadas pela existência de uma demanda potencial, podendo gerar novas capacidades de criação de novos consumos aos mercados. 
Assim, as empresas das indústrias de alimentos atuam no sentido de buscar novos mercados pelas inovações e diferenciações de seus produtos, direcionadas pela demanda. Este esforço generalizado não exclui a atividade da demanda criada naturalmente, de forma passiva, e percebida após o movimento das empresas, uma vez que ela é um processo de contínua mutação.

Toda essa análise é suficiente para justificar os investimentos em processos de flexibilização das plantas, corte de partes especiais de frango e industrialização das aves para comercialização de alimentos à base de frango, processo iniciado a partir de 1985, quando este tipo de produção começou a ganhar espaço no mercado internacional (Canever et al., 1997; Rizzi, 1993).

Sua verificação pode ser feita pelo aumento significativo na produção de produtos diferentes, não "commoditizados" e pela importância decrescente da produção e venda de produtos homogêneos, no caso frango inteiro, sendo que atualmente os cortes representam mais da metade das exportações nacionais, conforme ilustrado na Figura 14.

Vale ressaltar que a queda relativa no total dos produtos homogêneos não significa sua extinção ou não-investimentos em inovações tecnológicas para sua produção, muito menos a retirada de sua importância para o negócio. O crescimento do mercado foi refletido principalmente nos produtos diferenciados, com maior valor agregado e pela evolução nos números da demanda em todos os segmentos do mercado. 
2003

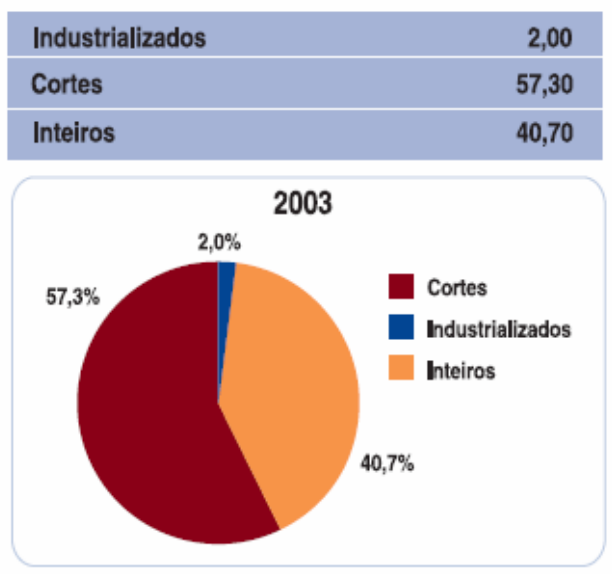

2002

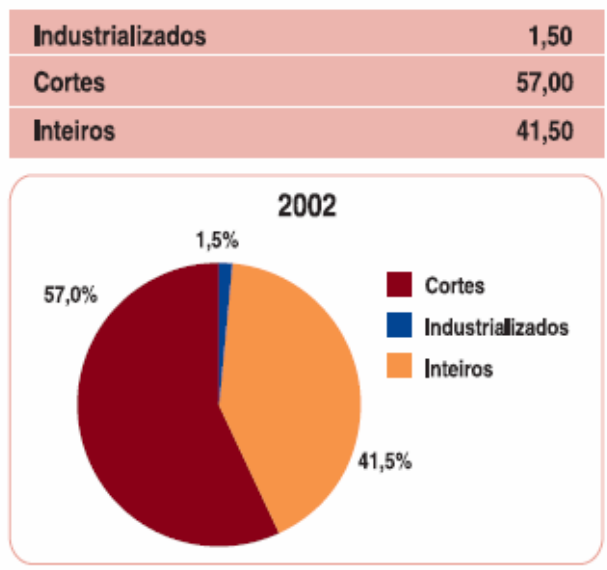

Figura 14 - Exportações brasileiras de carne de frango por segmento, em volume Fonte: ABEF (2003)

Em suma, três fatores devem ser destacados na análise da cadeia avícola: a dinâmica locacional geográfica e a estruturação da indústria, a flexibilidade da produção de acordo com as mudanças do mercado e a questão da tecnologia e diferenciação dos produtos na busca pela competitividade e crescimento possibilitados pelo modelo de integração vertical.

Quatro movimentos foram percebidos ao longo do processo de estruturação da indústria avícola: o primeiro, caracterizado pelo deslocamento geográfico para a região Sul do Brasil, iniciado nos anos 70, desconcentrando a produção do Estado de São Paulo e trazendo um novo modelo de governança para a cadeia.

O segundo foi a consolidação do modelo de integração vertical fundamentado nos anos 80 e 90, juntamente com a movimentação de expansão para a nova fronteira agrícola na região central brasileira.

O terceiro fator que se pode classificar como microeconômico, inclui os investimentos recentes em melhoramento genético, processos produtivos, produtos não "commoditizados" e marketing, os quais trouxeram para a indústria avícola a 
competitividade necessária para transformar o Brasil em um dos principais mercados fornecedores de aves.

O quarto e último são as atividades de otimização de processos de produção do frango e criação de áreas estratégicas internas às empresas de gestão de cadeia de suprimentos que sinalizam mudanças nos paradigmas atuais de planejamento integrado numa cadeia. O trabalho de Taube-Netto (1996) vai ao encontro deste movimento. Diante do cenário atual, discute-se na seção seguinte a importância da carne de frango para o Brasil.

\subsection{A importância da carne de frango para o Brasil}

No mercado de carne de frango, a produção mundial está estimada em 50,5 milhões de toneladas para o ano de 2004, sendo que o Brasil responde por aproximadamente 16,7\% deste total (8,45 milhões de toneladas) (ABEF, 2004 e União Brasileira de Avicultura (UBA), 2004).

O País não importa carne de frango, pelo contrário, é um dos principais exportadores. O mercado de exportação mundial está estimado em 5,8 milhões de toneladas, sendo que o Brasil responde com aproximadamente $31,9 \%$ do total $(1,85$ milhões de toneladas) (ABEF, 2004 e UBA, 2004).

Estima-se que a cadeia de frango movimente em torno de US $\$ 11,5$ bilhões, o equivalente a 6,5\% do PIB agropecuário, e empregue aproximadamente 1 milhão de pessoas (AveseOvos, 2004).

O setor de carnes no Brasil responde por uma parte significativa na sua balança comercial, com destaque para o frango, que somou US\$ 1,8 bilhão em 2003, $29 \%$ acima dos US\$1,4 bilhão do ano anterior (ABEF, 2004 e UBA, 2004).

A Tabela 1 mostra a divisão da exportação dos produtos no segmento carnes, evidenciando que a de frango é o principal produto exportado em quantidade e em valores monetários. É possível verificar que, em quantidade, ela contabilizou mais do 
que o dobro das exportações de carne bovina em toneladas. Entretanto, em receita, a bovina é a mais representativa para a balança nacional.

Tabela 1. Exportação brasileira de carnes em 2003, incluindo carnes industrializadas

\begin{tabular}{lcccc}
\hline Em t & $\begin{array}{c}\text { Participação } \\
\text { relativa }\end{array}$ & Em US\$ mil & $\begin{array}{c}\text { Participação } \\
\text { relativa }\end{array}$ \\
\hline Frango & 1.960 .000 & $58,32 \%$ & 1.799 .000 & $44,90 \%$ \\
Bovino & 800.000 & $23,80 \%$ & 1.510 .000 & $37,68 \%$ \\
Suíno & 491.000 & $14,61 \%$ & 546.000 & $13,63 \%$ \\
Peru & 110.000 & $3,27 \%$ & 152.000 & $3,79 \%$ \\
TOTAL & 3.361 .000 & & 4.007 .000 & \\
\hline
\end{tabular}

Fonte: UBA (2004)

Segundo a ABEF (2004) o valor obtido com as vendas no Exterior superou os EUA, tornando o Brasil o maior exportador de frango, em divisas.

Esse montante só não foi maior devido à imposição de cotas pela Rússia, principal mercado mundial do produto, trazendo destaque negativo ao causar redução de $38 \%$ nos embarques para aquele país em relação ao ano de 2002 . O cenário tende a mudar, pois os russos estão em fase de negociação e maior abertura de mercado aos produtos brasileiros.

Já em termos de produção, o Brasil é atualmente o segundo maior produtor de frango, perdendo apenas para os EUA. Há um cenário de mudança para 2004/2005, mas antes da conclusão deste trabalho não tinham sido divulgados, ainda, os dados oficiais.

A estimativa é de que o Brasil ocupe a segunda ou terceira posição, dependendo da classificação que se dará para a China. A Tabela 2 mostra a evolução da participação dos principais países na produção de frango. 
Tabela 2. Produção mundial de carne de frango, em milhares de toneladas

\begin{tabular}{lcccccc}
\hline \multicolumn{1}{c}{ MAIORES } & 1998 & 1999 & 2000 & 2001 & $2002^{1}$ & $2003^{1}$ \\
\hline EUA & 12.525 & 13.367 & 13.703 & 14.033 & 14.519 & 14.610 \\
Brasil & 4.498 & 5.526 & 5.980 & 6.567 & 7.040 & 7.843 \\
União Européia & 6.789 & 6.614 & 6.654 & 6.822 & 6.750 & 6.760 \\
China (PRC) & 3.450 & 4.400 & 5.050 & 5.200 & 5.400 & 5.450 \\
México & 1.587 & 1.784 & 1.936 & 2.067 & 2.188 & 2.135 \\
Japão & 1.097 & 1.078 & 1.091 & 1.074 & 1.090 & 1.080 \\
Tailândia & 930 & 980 & 1.070 & 1.230 & 1.320 & 1.380 \\
Canadá & 798 & 847 & 877 & 927 & 945 & 938 \\
Índia & 710 & 820 & 1.080 & 1.250 & 1.400 & 1.500 \\
Malásia & 660 & 684 & 786 & 813 & 832 & 846 \\
Outros países & 6.523 & 6.631 & 6.866 & 6.905 & 6.940 & 6.059 \\
Produção & 40.234 & 43.412 & 45.800 & 47.618 & 49.169 & 49.095 \\
mundial (total) & & & & & & \\
\hline
\end{tabular}

Fonte: Associação Paulista de Avicultura (APA) (2004), ABEF (2004) e Estados Unidos (2004)

1 dados preliminares

É possível verificar que o Brasil foi um dos únicos países que teve aumento de produção entre 2002 e 2003 de forma significativa, consolidando sua posição no mercado mundial.

A ABEF (2004) mostra que essa evolução foi devida, principalmente, à conquista de novos clientes (passando de 100 em 2002 para 122 em 2003, com estimativas para 130 em 2004); problemas sanitários em países europeus; gripe asiática no final de 2003, que prejudicou a produção de países importantes no mercado de frango, como China, Tailândia e a própria Comunidade Européia; câmbio favorável às exportações; investimentos em novos produtos para os mercados interno e externo.

De meados de 2004 para cá, o cenário cambial vem preocupando o setor exportador, uma vez que a moeda nacional passa por um processo de valorização mais alto do que percebido em outros países exportadores. 
Sendo assim, a análise do aumento das exportações é fator essencial para explicar o crescimento do setor. Da produção brasileira, quase um quarto do total é destinado ao mercado externo, como mostra a Tabela 3.

Tabela 3. Produção brasileira de carne de frangos (em toneladas) e mercados consumidores

\begin{tabular}{cccccc}
\hline Ano & $\begin{array}{c}\text { Mercado } \\
\text { Interno }\end{array}$ & Exportação & Total & $\begin{array}{c}\text { Participação } \\
\text { Mercado } \\
\text { Interno }\end{array}$ & $\begin{array}{c}\text { Participação } \\
\text { Exportação }\end{array}$ \\
\hline 1990 & 1.968 .069 & 299.218 & 2.267 .358 & $86,8 \%$ & $13,2 \%$ \\
1991 & 2.200 .211 & 321.700 & 2.521 .911 & $87,2 \%$ & $12,8 \%$ \\
1992 & 2.350 .567 & 371.719 & 2.726 .992 & $86,2 \%$ & $13,6 \%$ \\
1993 & 2.709 .500 & 433.498 & 3.142 .998 & $86,2 \%$ & $13,8 \%$ \\
1994 & 2.929 .997 & 481.029 & 3.411 .026 & $85,9 \%$ & $14,1 \%$ \\
1995 & 3.616 .705 & 428.988 & 4.050 .449 & $89,3 \%$ & $10,6 \%$ \\
1996 & 3.482 .767 & 568.795 & 4.051 .561 & $86,0 \%$ & $14,0 \%$ \\
1997 & 3.811 .569 & 649.357 & 4.460 .925 & $85,4 \%$ & $14,6 \%$ \\
1998 & 4.262 .231 & 612.417 & 4.874 .708 & $87,4 \%$ & $12,6 \%$ \\
1999 & 4.755 .492 & 770.551 & 5.526 .044 & $86,1 \%$ & $13,9 \%$ \\
2000 & 5.069 .777 & 906.746 & 5.976 .523 & $84,8 \%$ & $15,2 \%$ \\
2001 & 5.486 .408 & 1.249 .288 & 6.735 .696 & $81,5 \%$ & $18,5 \%$ \\
2002 & 5.917 .000 & 1.599 .923 & 7.516 .923 & $78,7 \%$ & $21,3 \%$ \\
2003 & 5.920 .908 & 1.922 .042 & 7.842 .950 & $75,5 \%$ & $24,5 \%$ \\
\hline
\end{tabular}

Fonte: ABEF (2004)

Alguns dados das Tabelas 2 e 3 não são exatamente os mesmos, todavia estão muito próximos devido às fontes utilizadas para a confecção dos números garantindo a grandeza dos dados apresentados.

Do total exportado em 2003, a Tabela 4 mostra os destinos, a participação absoluta em toneladas e a participação relativa. 
Tabela 4. Destino e porcentagem das exportações brasileiras de frango de corte e inteiro

\begin{tabular}{|c|c|c|c|c|c|c|}
\hline Destino & Inteiro & $\%$ & Cortes & $\%$ & Total & $\%$ \\
\hline $\begin{array}{l}\text { Oriente } \\
\text { Médio }\end{array}$ & 557.164 .780 & $69,82 \%$ & 46.221 .367 & $4,11 \%$ & 603.386 .147 & $31,39 \%$ \\
\hline Ásia & 34.024 .147 & $4,26 \%$ & 450.146 .368 & $40,05 \%$ & 484.170 .515 & $25,19 \%$ \\
\hline Europa & 106.658 .332 & $13,36 \%$ & 227.881 .028 & $20,27 \%$ & 334.539 .360 & $17,41 \%$ \\
\hline $\begin{array}{l}\text { União } \\
\text { Européia }\end{array}$ & 17.330 .654 & $2,17 \%$ & 268.825.598 & $23,92 \%$ & 286.156 .252 & $14,89 \%$ \\
\hline África & 50.078 .785 & $6,28 \%$ & 95.978 .860 & $8,54 \%$ & 146.057 .645 & $7,60 \%$ \\
\hline $\begin{array}{l}\text { América } \\
\text { Central }\end{array}$ & 5.021 .051 & $0,63 \%$ & 23.770 .654 & $2,11 \%$ & 28.791 .705 & $1,50 \%$ \\
\hline $\begin{array}{l}\text { América do } \\
\text { Sul }\end{array}$ & 24.910 .375 & $3,12 \%$ & 3.192 .951 & $0,28 \%$ & 28.103.326 & $1,46 \%$ \\
\hline Outros & 2.856 .340 & $0,36 \%$ & 7.980 .814 & $0,71 \%$ & 10.837 .154 & $0,56 \%$ \\
\hline TOTAL & 798.044 .464 & & 1.123 .997 .640 & & 1.922 .042 .104 & \\
\hline
\end{tabular}

Fonte: UBA (2004)

Os investimentos em novos produtos, em detrimento do frango inteiro, foram os propulsores do aumento. Novos cortes e industrialização de produtos agregam valor ao produto final, diferenciado-os no mercado e possibilitando aumento de suas margens.

Os dados ilustrados nas Tabelas 2, 3 e 4 demonstram o que foi comentado na seção anterior sobre a necessidade da busca de novos mercados e diferenciação dos produtos.

Internamente, a distribuição da produção em todos os estágios da cadeia se concentra na região Sul. Mais especificamente, as regiões Sul e Sudeste respondem por mais de $80 \%$ do negócio do frango nacional. Na Tabela 5 há a distribuição por regiões brasileiras dos três principais estágios da cadeia de produtiva. 
Tabela 5. Distribuição por região brasileira de alojamento de matrizes, produção de pintos para corte e abate de frango com SIF em 2003

\begin{tabular}{|c|c|c|c|c|c|c|}
\hline \multirow[b]{2}{*}{ Região } & \multicolumn{2}{|c|}{$\begin{array}{c}\text { Alojamento de } \\
\text { Matrizes de Corte e } \\
\text { Postura }{ }^{1} *\end{array}$} & \multicolumn{2}{|c|}{$\begin{array}{l}\text { Produção de Pintos de } \\
\text { Corte }^{2 * *}\end{array}$} & \multicolumn{2}{|c|}{$\begin{array}{l}\text { Abate de Frango de Corte } \\
\text { por Região com } \operatorname{SIF}^{3 * * *}\end{array}$} \\
\hline & Matrizes & $\%$ & Pintos & $\%$ & Cabeças & $\%$ \\
\hline Sul & 18.040 .461 & 58,13 & 2.139 .974 .375 & 54,77 & 2.064 .340 .409 & 64,24 \\
\hline Sudeste & 8.768 .172 & 28,25 & 1.121 .697 .793 & 28,71 & 705.935.301 & 21,97 \\
\hline Centro-Oeste & 2.377 .363 & 7,66 & 324.324 .581 & 8,30 & 347.946 .836 & 10,83 \\
\hline Nordeste & 1.815 .525 & 5,85 & 281.074 .802 & 7,19 & 74.130 .841 & 2,31 \\
\hline Norte & 33.535 & 0,11 & 40.052 .372 & 1,03 & 21.050 .480 & 0,66 \\
\hline TOTAL & 31.035 .056 & & 3.907.123.923 & & 3.213 .403 .867 & \\
\hline
\end{tabular}

Fonte: ${ }^{1}$ UBA (2004), ${ }^{2}$ Associação Paulista dos Produtores de Pinto para Corte (APINCO) (2004) e ${ }^{3}$ UBA/ABEF (2004)

* em unidades de matrizes;

** em unidades de pintos;

*** em unidades de cabeças

Os dados apresentados na Tabela 5 confirmam a liderança da região Sul no negócio aves, demonstrando que a estrutura de governança integrada verticalmente hoje vigente é predominante e traz benefícios para toda a cadeia.

É possível afirmar que o sistema integrado tende a aumentar nos próximos anos, fazendo diminuir a atividade dos produtores independentes.

\subsection{A gestão da cadeia de suprimentos de frango no Brasil}

\subsubsection{A cadeia produtiva de aves de corte}

Dörr (2003) mostra que o ambiente da cadeia de aves é extremamente amplo, envolvendo cooperativas, associações de classe, sindicatos e integrações de produtores e governo. O material genético utilizado para reprodução é importado e repassado, mediante acordos com firmas estrangeiras, para as integradoras nacionais ou terceiros que produzem, localmente, os plantéis de bisavós, avós e, por fim, as matrizes. 
Dörr (2003, p.8) cita claramente que a cadeia produtiva de aves de corte se inicia "nas rações e são principalmente distribuídas pelos integradores aos produtores de frangos, podendo existir firmas independentes para produção de rações. A produção de frangos faz parte do processo coordenado pelas indústrias frigoríficas. A indústria de insumos e equipamentos coloca-se como fornecedora de bens e serviços ao complexo agroindustrial. A industrialização de produtos e sua distribuição fazem parte da integração vertical, sendo que a venda a varejo no mercado interno se dá por terceiros. As exportações são comandadas pelas empresas integradoras".

A Figura 15 mostra a cadeia produtiva completa descrita para aves de corte, desde a importação de material genético para reprodução até a venda final para o consumidor, com foco nas atividades produtivas.

O seu detalhamento está elevado para o que se pretende neste trabalho. Portanto, mais adiante, haverá o agrupamento destas atividades por elos, seguindo o recomendado por Lambert et al. (1998), Chopra \& Meindl (2003) e Pires (2004) no que diz respeito à seleção daqueles classificados como primários e de suporte na cadeia de suprimentos.

Portanto, serão focados elos primários e que estejam sob o domínio vertical do elo centralizador da cadeia do frango. 


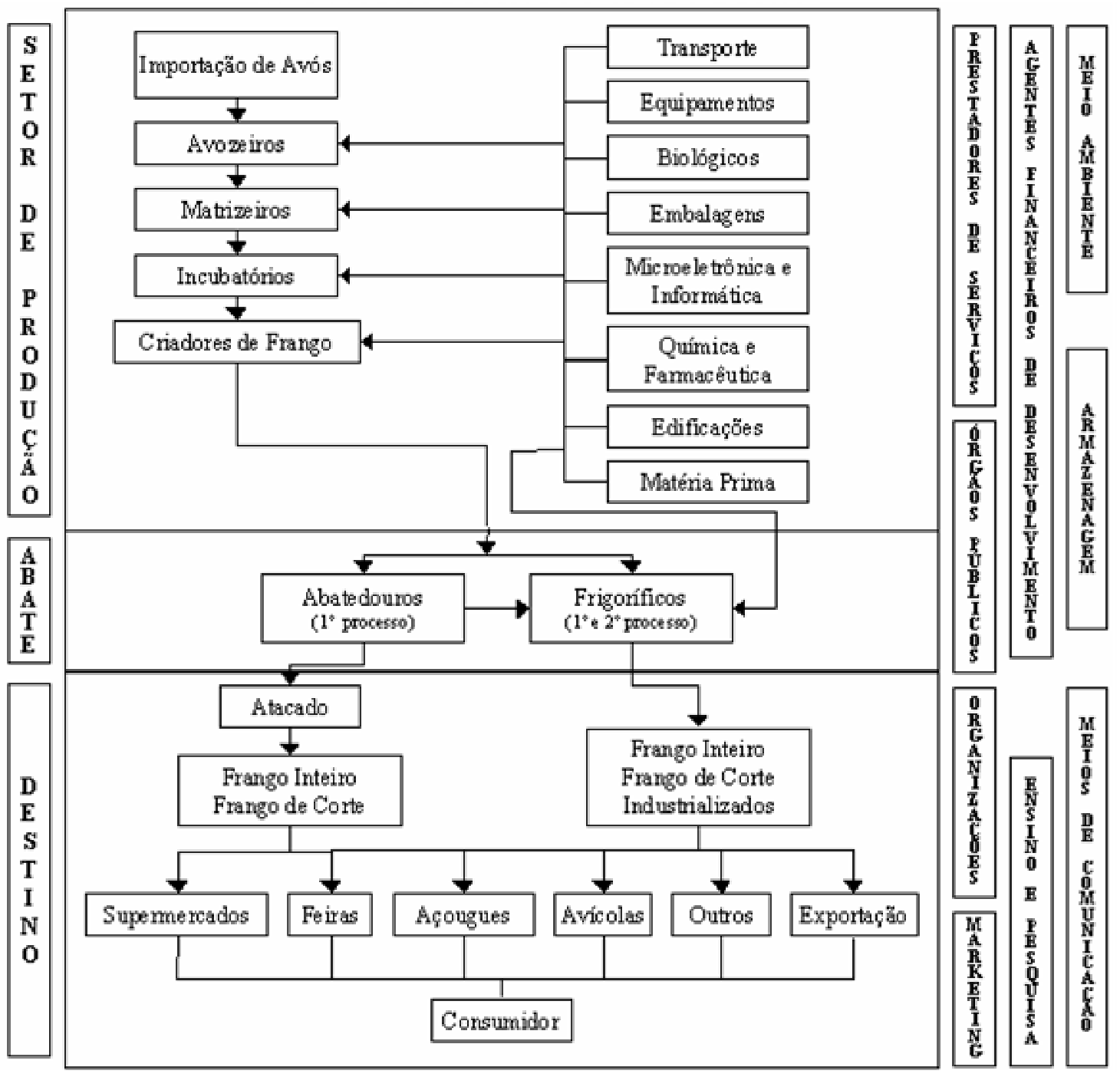

Figura 15 - Cadeia produtiva de aves de corte

Fonte: Dörr (2003)

\subsubsection{A cadeia de suprimentos de aves de corte no sistema integrado}

A produção do frango começa com o plantio do milho e da soja, o primeiro elo da cadeia. Os grãos são obtidos no mercado, não fazendo parte da cadeia integrada verticalmente.

Esses produtos seguem dois destinos: as fábricas de rações e as fábricas de óleo (os primeiros elos da cadeia integrada verticalmente), que levam seus produtos 
diretamente para o mercado ou para a fabricação de farelo, também consumido pela fábrica de ração. Este é o segundo elo da cadeia.

O terceiro inclui as fábricas de ração que processam as matérias-primas, levando seu produto final às granjas de aves e suínos, o quarto elo da cadeia. A produção de aves ocorre em conjunto com a produção de suínos em granjas próprias. Nelas há o estudo genético apurado das linhas, os chamados avós (primeira geração) até a produção de matrizes (segunda geração), as quais são as produtoras dos ovos que gerarão os frangos a serem consumidos no mercado (terceira geração).

Os ovos são enviados aos incubatórios, o quinto elo, onde serão incubados até o nascimento dos pintos. Estes são enviados aos integrados quando estiverem com um dia de vida. Os integrados, constituindo o sexto elo da cadeia, são os responsáveis pela criação e crescimento dos pintos até o ponto de abate.

Após o período de crescimento os frangos são levados aos frigoríficos, onde serão abatidos, cortados e embalados, caracterizando o sétimo elo. Em seguida, estes produtos passam pela indústria, o oitavo elo da cadeia, onde são industrializados.

Após o processo de industrialização, o produto final pode seguir para três canais distintos, via distribuidor (o nono elo): mercado externo, centros de distribuição ou redes de supermercados, todos considerados como o décimo elo da cadeia.

As redes de supermercados também podem receber produtos vindos do canal dos centros de distribuição, assim como do varejo antes de chegar ao consumidor final, o último elo da cadeia. Essa descrição é a visão integrada do processo de industrialização e distribuição do frango.

O processo está esquematicamente apresentado na Figura 16. 


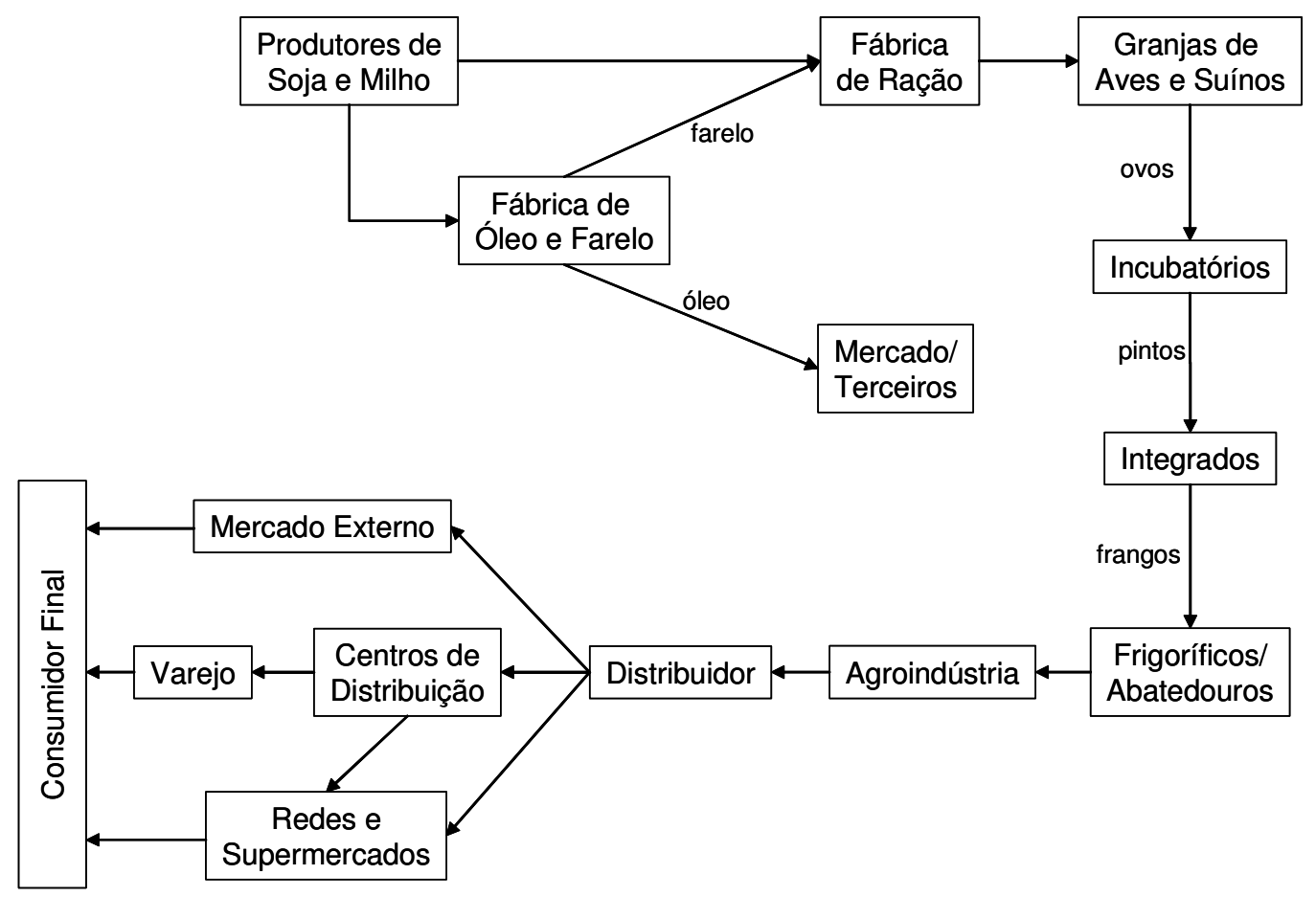

Figura 16 - Cadeia de suprimentos do frango

A análise de todos os elos primários envolvidos nessa cadeia pode ser comparada com a cadeia de suprimentos completa, sugerida por Chopra \& Meindl (2003), uma vez que é possuidora de todos os estágios.

Sendo assim, com foco na agroindústria como a detentora das demais empresas integradas, os fornecedores em diversos níveis são os produtores de milho, fábrica de óleo e farelo, fábrica de ração, granjas de aves e suínos, incubatórios e os integrados. Todos são classificados como fornecedores de nível um até seis, dependendo da "distância" até a agroindústria.

Em seguida, os frigoríficos/abatedouros e o fabricante, principal elemento da análise de uma cadeia, são classificados como a agroindústria, transformadora dos produtos antes da distribuição. O distribuidor envia os produtos para três tipos distintos de destinos, podendo passar pelo varejista antes de chegar ao consumidor final. 
Todos os demais - fornecedores de vacinas, prestadores de serviços, agentes financeiros, operadores logísticos, consultores, dentre outros - serão classificados como elos de suporte.

\subsubsection{Alinhamento estratégico na cadeia de suprimentos do frango ${ }^{12}$}

A apresentação da cadeia de frango e de seu desenvolvimento empresarial no Brasil sugere seu posicionamento avançado nas fases se comparado à análise da evolução da logística apresentada no Quadro 1.

A questão do uso de contratos com fornecedores de grãos, parcerias, cooperação e da colaboração na gestão da cadeia é algo latente, passível desta classificação.

Rizzi (1993, p.72) mostra que novos produtos de maior valor agregado são inseridos no mercado todos os dias, como pode ser visto nas prateleiras de supermercados, varejistas e mercados em geral.

Ademais, as mudanças nos cardápios, cortes adaptados a restaurantes, variedade de cortes para facilitar o cozimento caseiro com sugestões de receitas que podem ser adaptadas pelo consumidor segundo seus próprios gostos, itens semi-prontos e até prontos para comer, além da atual disseminação do consumo de alimentos mais saudáveis, como a carne branca, são alguns exemplos de novos produtos e paradigmas lançados constantemente.

Entretanto, a garantia de suprimento dessa gama de novos produtos demanda um sistema logístico complexo que sustente as diversas atividades e fatores-chave para que atenda todas as necessidades operacionais.

Algumas dessas atividades receberam facilidades operacionais com 0 advento da informática, como pode ser visto pelos sistemas de otimização de processos,

12 Esta seção foi embasada basicamente no trabalho de Rizzi (1993) e na revisão de literatura do Capítulo 2 deste trabalho. 
planejamento integrado, troca de dados entre os elos (Taube-Netto, 1996), controle de qualidade via raios-x e infravermelho, para citar apenas alguns exemplos.

Outras atividades são sustentadas pela estrutura trazida da integração vertical e seus benefícios de custo, de possível redução de estoques nos elos, ganhos sinérgicos, sincronismo das informações e planejamentos integrados com mais acurácia, todos em acordo com as vantagens da integração.

Em linhas gerais, a gestão das funções da cadeia de valor, principalmente as atividades operacionais logísticas, constitui a síntese central da organização, da informação e da tecnologia presente.

A complexidade trazida para os novos produtos também foi discutida por Rizzi (1993) como exercida em grande parte pelas líderes de mercado, que atuam no topo da estrutura industrial devido ao seu elevado grau de investimento e risco trazidos pela não-aceitação dos novos produtos pelo consumidor, a ponto de não afetar a estrutura financeira da empresa.

Nessa cadeia, além da informatização e da tecnologia, a distribuição merece extremo destaque e atenção dos gestores. A otimização dos estoques na distribuição de produtos finais e a garantia do fluxo regular das matérias-primas padronizadas e com elevado controle de qualidade mostraram-se fundamentais para o negócio de forma integral (Rizzi, 1993).

Muito do sucesso na distribuição de matéria-prima foi conseguido pelo modelo de coordenação vertical com os produtores agrícolas, podendo até ser feita uma analogia com o Just-in-Time II do sistema de produção enxuta, ao se atingir próximo a um ótimo mínimo de estoque de matéria-prima (aves vivas) pertencente aos produtores terceirizados (integrados) e que serão consumidos segundo uma programação préagendada e com metas de produção (planejamento integrado).

A gestão da demanda integrada é um fator de sucesso nessa cadeia. Uma gestão mal realizada pode desbancar todo o esforço da cadeia na busca do lucro. $\mathrm{O}$ dimensionamento da previsão de vendas maior que a demanda real vai exigir vendas 
forçadas no final da produção. Para consolidar a prática, preços mais baixos e promoções são estimulados ao mercado, caracterizando o descompasso de planejamento e previsão.

Já no caso da distribuição de produtos finais, o uso de diversos canais e centros de distribuição (CDs) próprios espalhados ao longo do território nacional garantem a capilaridade da oferta do produto no mercado consumidor, uma vez que se trata de produtos perecíveis de consumo alimentar com data de expiração relativamente curta.

Surge, assim, a necessidade do controle da velocidade do fluxo de estocagem (giro dos estoques) e de distribuição dos produtos finais, uma vez que nesse mercado há um elevado grau de substitubilidade e o consumidor não aceita esperar o envio do produto para a sua aquisição. Ele deve estar presente no momento exato da compra, caracterizando um alto nível de serviço.

Entretanto, seria incompleto afirmar que a freqüência de reabastecimento nos canais de distribuição varejo e atacado são exclusivamente ditados por fatores técnicos. É fato a sua grande importância para a logística e gestão da cadeia de suprimentos, mas traz limitações técnicas importantes para as empresas comerciais.

Atualmente, o fator estoque na cadeia é passível de otimização matemática e passa por evoluções técnicas diversas que ajudam a diminuir o capital de giro parado em estoques. Do mesmo modo, seguem os transportes, principalmente na busca de capilaridade e disponibilidade dos produtos.

Portanto, a freqüência de reabastecimento é menos dependente da validade dos produtos e mais do capital de giro ou giro de estoque empregado para o faturamento final, ponto onde há diversos estudos sobre melhoria de gestão e redução de custos (Green \& Schaller, 2000). Para alguns gestores e pesquisadores da área, este pode ser um bom argumento para um medidor de desempenho da cadeia de suprimentos. 
Ao considerarmos a cadeia do frango, é necessário vincular quais os produtos a serem analisados. Isto remonta a análises sobre qual o melhor alinhamento estratégico adaptado para a cadeia de suprimentos do produto.

O abate do frango é considerado o núcleo do processamento industrial e dele segue o desdobramento na elaboração dos cortes e industrialização. Portanto, o frango abatido segue dois caminhos: a sua venda para o mercado consumidor e matéria-prima para a integração vertical para frente de cortes e industrialização (Rizzi, 1993).

Em primeira instância será analisada a cadeia do frango inteiro (com baixo valor agregado) e, em seguida, a cadeia do frango de cortes e industrialização (com alto valor agregado) como duas vertentes iniciais de estudo.

Existem diversas exigências a serem cumpridas antes de qualquer empresa poder comercializar o produto frango tanto no mercado interno quanto no externo. Uma vez que elas sejam alcançadas, o frango inteiro posto no mercado é considerado como uma commodity mundial (Canever et al., 1997).

Segundo a visão de marketing, qualquer frango inteiro de mesma raça, idade e princípio genético produzido nos quatro cantos do mundo e passível de comercialização é considerado semelhante.

Sendo assim, esse produto é visto como funcional. Não há inovação ou agregação de valor para o mercado, mas necessidade de produção e de comercialização em massa, economias de escala, pontualidade de entrega e normalmente produção sob demanda de pedido (praticado principalmente para vendas no mercado externo).

Numa primeira análise, essas características são basicamente de cadeias eficientes; portanto, o foco principal de gestão deve ser o custo total para análise do custo do produto final. Percebe-se que a diferenciação não tem significado para este produto e houve uma nítida passagem da busca pela velocidade e disponibilidade no mercado.

Já o frango abatido merece uma análise um pouco mais detalhada. Como citado anteriormente, o frango inteiro é matéria-prima para os cortes e industrialização 
da carne. A transformação, industrialização e agregação de valor demandam atividades extras e planejamento específico. É claro, portanto, que o custo deve ser necessariamente superior ao do frango inteiro. Pela teoria proposta, este produto é mais próximo do tipo inovador do que funcional, cabendo assim uma estratégia de cadeia responsiva.

Ora, essa análise não é tão simplista como aparenta. Favaret-Filho \& Paula (1997) citam que a oferta da carne de frango propiciou ao consumidor uma alternativa à carne bovina.

Além do crescimento da oferta, o preço da carne do frango é mais acessível à população de baixa renda, o que implica considerar que se trata de uma substituta da carne bovina.

AveseOvos (2004) mostrou que, em 1989, o preço da carne de frango ao consumidor era o mesmo do corte bovino denominado acém, uma carne de segunda qualidade e considerada como popular no mercado. Com o passar do tempo houve defasagem de preço da carne de frango em relação ao acém; em 2004 girava em torno de $46 \%$, o que confirma aumento da popularização do frango.

No mesmo sentido, Azevedo \& Bankuti (2004) comentam sobre a clandestinidade no mercado de produtos alimentares no Brasil, em especial para a carne bovina, fator considerado como reflexo direto do poder aquisitivo nacional, da tributação excessiva e da elevada burocracia.

A clandestinidade é fator importante para redução de preços no mercado, forçando empresas a reduzirem custos para não perderem vendas. Por outro lado, ela não é tão operante no sistema frango, pois a integração já possui patamares elevados, próximos dos $75 \%$ da produção total nacional (AveseOvos, 2004). Entretanto, por ser um produto substituto da carne bovina, é possível afirmar que, indiretamente, há impactos na pressão de queda nos preços do frango.

Souza et al. (2004) mostram que na cadeia de frango a diferenciação está presente na inovação, na qualidade do produto, na rapidez da entrega, na promoção de 
vendas e na publicidade. Ainda existe grande lealdade em relação à marca e o preço é fator determinante da variação do consumo.

Portanto, a análise da cadeia de suprimentos do frango indica que se deve levar em consideração custo (eficiência) e rapidez (responsividade) juntos, fatores que não podem se desvincular das análises mesmo para produtos diferentes.

Assim, a visão passa diretamente para a cadeia de estratégia híbrida. O alinhamento entre os elos à jusante do fabricante sugere a cadeia eficiente, com foco na redução de custos, ganho em escala de produção, maximização do uso dos equipamentos e otimização de matéria-prima de aves vivas nos integrados. O seu dimensionamento pode ser obtido por meio da gestão da demanda e a aplicação dos conceitos de produção em massa empurrado no sistema até o CD.

Desse ponto em diante, à montante da cadeia, a capilaridade do sistema logístico e dos canais de distribuição que garantem a oferta do produto sugere a velocidade no desenvolvimento dos fatores-chave da cadeia, estágio este muito próximo do ponto de desacoplamento na cadeia de suprimentos do frango.

O consumo do mercado no curto prazo e os pontos de reabastecimentos locais podem ser supridos utilizando-se das técnicas de JIT do sistema de produção puxada de acordo com a movimentação da demanda real. Assim, os CDs contemplam o planejamento de médio-longo prazos com previsão de demanda e o reabastecimento do mercado pode ser feito pela velocidade de resposta do consumo momentâneo ao mesmo tempo.

Os fatores de perecibilidade e de substitubilidade dos produtos finais podem atingir níveis baixos, abrindo espaço para diversos pontos de otimização logística em transporte, em armazenagem e em giro de estoques. A Figura 17 ilustra o que foi discutido, tomando como referência o escopo originalmente apresentado na Figura 7. 


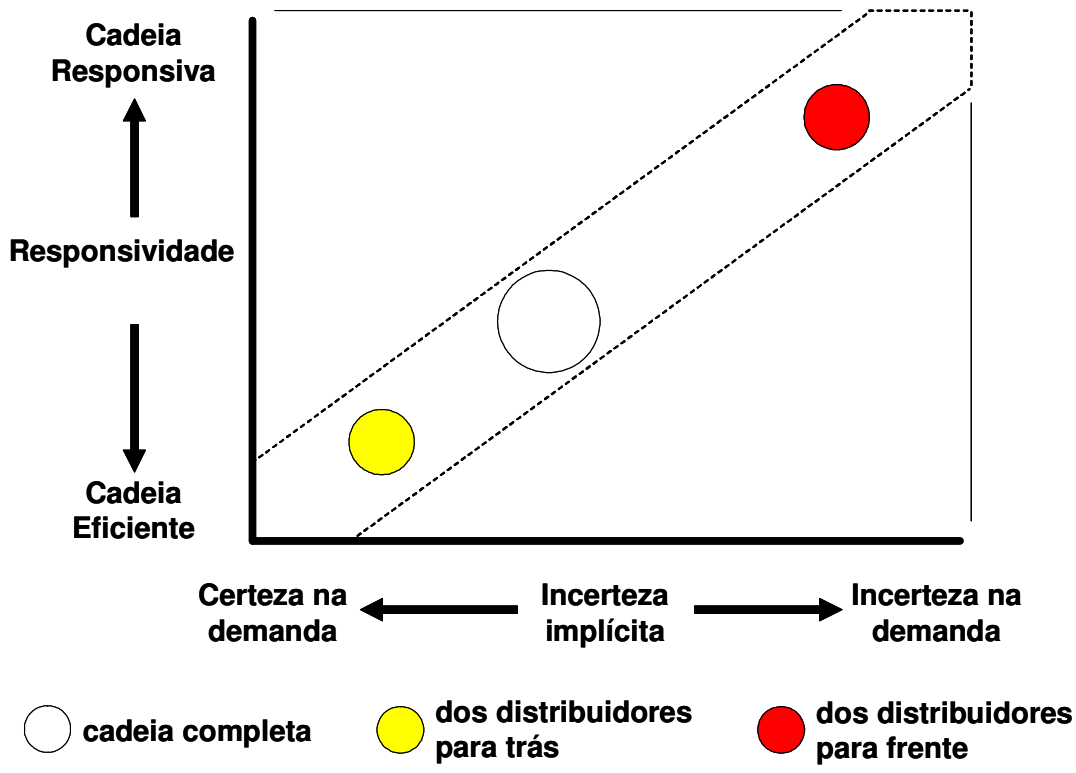

Figura 17 - Posicionamento da cadeia do frango na zona de alinhamento estratégico

Devido a essas explicações, o modelo que será proposto para se analisar a cadeia do frango contemplará o negócio agregado. Em outras palavras, é possível realizar uma análise macro da cadeia sem diferenciação por produto (funcional ou inovador) ou até mercado, num primeiro momento.

O capítulo seguinte sugere um modelo de análise da cadeia integrada de frango segundo custos operacionais e de transação (nem sempre mensuráveis), contemplando ambos fatores - de custos e de rapidez - pela estratégia adotada na cadeia, segundo um estudo de caso. 


\section{METOdologia PARA ANÁlise de CUSTOS NA CADEIA DE SUPRIMENTOS}

Neste capítulo serão apresentados os aspectos metodológicos propostos para se analisar a estratégia da cadeia de suprimentos segundo custos em todos os elos de uma cadeia integrada verticalmente.

A busca das informações foi realizada pelo método Delphi. Como embasamento teórico, foi utilizada a metodologia de estudo de caso único exploratório de Yin (2002) para validação da metodologia proposta de análise de custos.

\subsection{Modelo de eficiência para canais de distribuição ${ }^{13}$}

Coughlan et al. (2002) propõem uma metodologia de análise do canal de distribuição segundo o chamado Modelo de Eficiência do canal. O estudo original é aplicado segundo análise dos canais de distribuição para os elos de uma cadeia de suprimentos, ou seja, os que não mais modificam o produto, mas agregam valor em serviços.

Canais de distribuição são geralmente compostos por quatro elos principais: fabricante ou produtor, atacadista/varejista (estes dois últimos são também conhecidos como intermediários) e consumidor final (Consoli et al., 2004).

Portanto, se forem comparados os elos adotados pelo canal de distribuição em Coughlan et al. (2002) com os elos indicados na Figura 3, a cadeia de suprimentos completa não é contemplada, mas somente do produtor até o cliente final.

\footnotetext{
${ }^{13}$ Este tópico foi embasado essencialmente em Coughlan et al. (2002), pioneiros no desenvolvimento da metodologia apresentada.
} 
O modelo de eficiência avalia os custos incorridos e/ou valor agregado por cada membro do canal de distribuição para analisar o desempenho individual dos elos nos fluxos de canal.

Os custos podem ser divididos como sendo de transação, contábeis e operacionais. Deve, também, ser realizada uma análise de modelo de eficiência por canal utilizado na distribuição do produto. Este pressuposto é importante para o entendimento do modelo e da proposta do presente trabalho.

Em marketing, fluxo de canal é definido como sendo as atividades ou as funções realizadas em diferentes momentos, por diferentes membros, a fim de se atingir o objetivo principal do canal de marketing, ou seja, disponibilizar um produto ou serviço para o consumo (Stern et al., 1996; Besanko et al., 2000; Coughlan et al., 2002).

O esforço do canal inclui o desempenho de vários fluxos de marketing. Os principais são: posse física, propriedade, promoção, negociação, financiamento, risco, informação, pedido e pagamento, descritos por Coughlan et al. (2002, p.87) da seguinte forma:

- Posse física: custos de armazenagem, entregas e manutenção;

- Propriedade: custos de manutenção em estoques;

- Promoção: custos de venda pessoal, propaganda, promoção de venda;

- Negociação: custos de tempos legais para negociação;

- Financiamento: custos de condições de crédito, prazos e condições de vendas;

- Risco: custos de garantia de preços, seguro e pós-venda;

- Informação: custos de informações necessárias para planejamento;

- Pedido: custos de processamento do pedido;

- Pagamento: custos de dívidas de recebimento duvidoso.

Ao se imaginar um canal hipotético, os fluxos podem ser esboçados tal como ilustrados na Figura 18. 


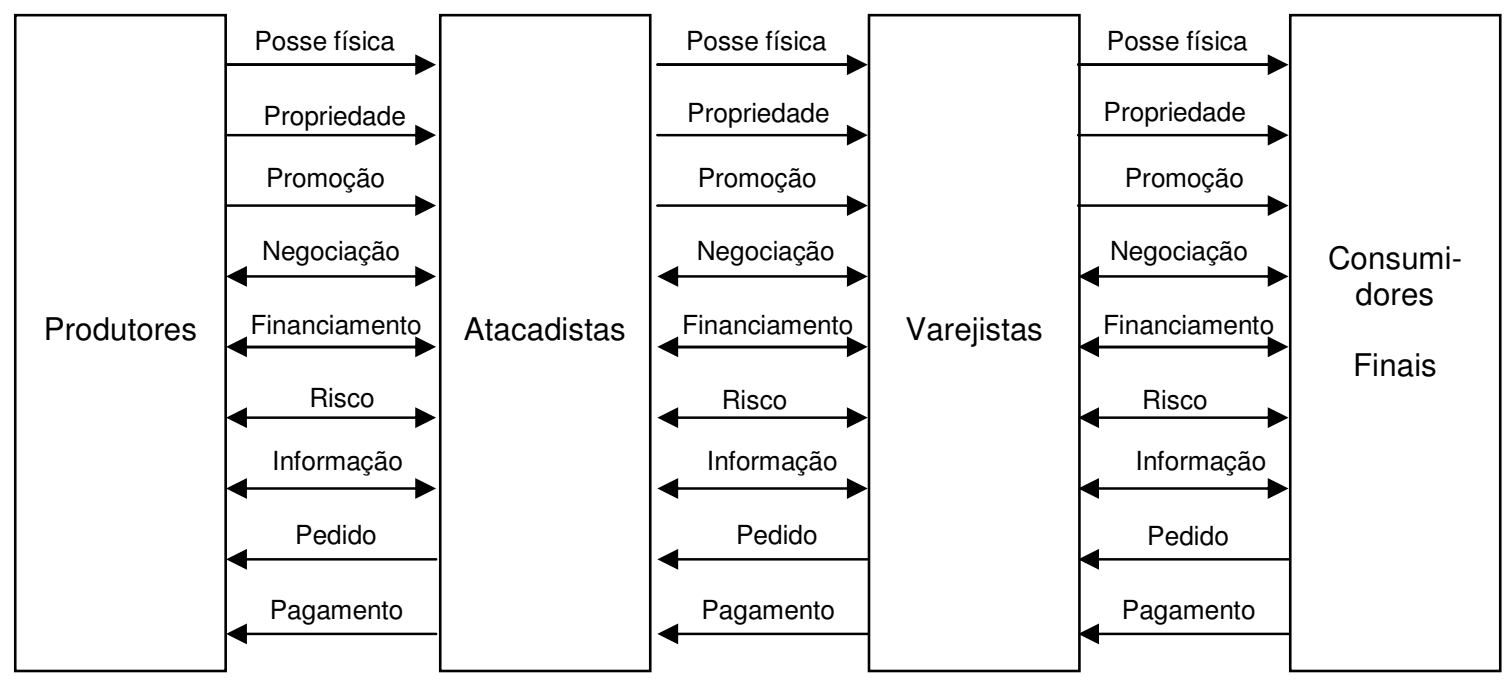

Figura 18 - Fluxos de marketing em canais de distribuição

Fonte: Consoli et al. (2004), adaptado de Couglhan et al. (2002)

Cada fluxo segue a sua direção, podendo ela ser a favor ou contra o fluxo do produto ou até em ambos os sentidos, o que vai depender das atividades que cada fluxo desempenha, de acordo com as necessidades física e informacional do que se busca no negócio.

Segundo Coughlan et al. (2002), o modelo de eficiência descreve três principais características empresariais do canal:

1. Os tipos e as quantidades de trabalho realizados em cada membro do canal no desempenho do fluxo de canal;

2. A importância de cada fluxo de canal para o fornecimento de prestações de serviços demandadas pelo consumidor;

3. A participação resultante dos lucros totais do canal que cada elo deveria receber. 
A análise busca fazer a divisão "justa" de lucros do canal e deve ser coerente com o valor agregado ao produto final, resultado dos cálculos na análise do quadro do modelo de eficiência.

A divisão é baseada no custo total direta ou indiretamente relacionado ao valor que cada elo agrega ao produto. Este princípio é também conhecido como "princípio da eqüidade" (Coughlan et al., 2002) ou "marginalização dupla" (Chopra \& Meindl, 2003).

Numa segunda possível análise, os custos divididos entre os elos também podem ser usados, dependendo de como se aplica essa metodologia. Mais adiante, será apresentada uma adaptação e em seguida uma aplicação para análise de divisão de custos na cadeia do frango, foco central do estudo de caso.

A teoria sugere que para cada canal de distribuição de uma empresa (ou cadeia ou até produto) deve ser realizado um modelo de eficiência, o que pressupõe diversas análises para contemplar todos os produtos e canais envolvidos. Dependendo do “caminho" que o produto seguirá até chegar ao cliente final, um fluxo pode assumir mais importância que outro.

No mesmo sentido, os custos provavelmente se diferenciarão uns dos outros para cada canal. Daí a necessidade da aplicação da metodologia por canal e por produto. Há ainda a personalização de fluxos de canais para adaptação do negócio a ser analisado.

A Tabela 6 indica a tabulação dos fluxos de marketing para preenchimento das informações segundo o modelo de eficiência em estrutura de matriz. 
Tabela 6. O modelo de eficiência e fluxos de marketing

\begin{tabular}{|c|c|c|c|c|c|c|c|c|}
\hline & \multicolumn{3}{|c|}{ Pesos para os fluxos } & \multicolumn{4}{|c|}{$\begin{array}{c}\text { Desempenho proporcional de fluxo } \\
\text { dos membros ou elos do canal }\end{array}$} & \multirow[b]{2}{*}{$\begin{array}{l}\text { To- } \\
\text { tal } \\
(\%)\end{array}$} \\
\hline & Custos & $\begin{array}{l}\text { Potencial } \\
\text { de } \\
\text { benefício } \\
\text { (alto, } \\
\text { médio ou } \\
\text { baixo) }\end{array}$ & $\begin{array}{l}\text { Peso } \\
\text { Final }\end{array}$ & $\begin{array}{l}\text { Produ- } \\
\text { tor }\end{array}$ & $\begin{array}{l}\text { Ataca- } \\
\text { dista }\end{array}$ & $\begin{array}{l}\text { Vare- } \\
\text { jista }\end{array}$ & $\begin{array}{l}\text { Consu- } \\
\text { midor }\end{array}$ & \\
\hline Posse física & & & & & & & & 100 \\
\hline Propriedade & & & & & & & & 100 \\
\hline Promoção & & & & & & & & 100 \\
\hline Negociação & & & & & & & & 100 \\
\hline Financiamento & & & & & & & & 100 \\
\hline Risco & & & & & & & & 100 \\
\hline Informação & & & & & & & & 100 \\
\hline Pedido & & & & & & & & 100 \\
\hline Pagamento & & & & & & & & 100 \\
\hline TOTAL & $100 \%$ & - & $100 \%$ & - & - & - & - & - \\
\hline $\begin{array}{l}\text { Participação } \\
\text { normativa nos } \\
\text { lucros }\end{array}$ & - & - & - & $\%$ & $\%$ & $\%$ & $\%$ & 100 \\
\hline
\end{tabular}

Fonte: Consoli et al. (2004), adaptado de Coughlan et al. (2002)

Para melhor compreensão de como preencher a Tabela 6 com os dados, segue a explanação textual e a especificação matemática correspondente.

Primeiramente, a Tabela 6 será dividida em três partes: as linhas $i$, as colunas $j$ dos "Pesos para os fluxos" e as colunas $k$ do "Desempenho proporcional de fluxo dos membros ou elos do canal". Ainda, $m=$ número total de fluxos de marketing e $n=$ número total de elos do canal de distribuição. A Tabela 7 ilustra estas denominações. 
Tabela 7. As divisões matriciais no quadro do modelo de eficiência

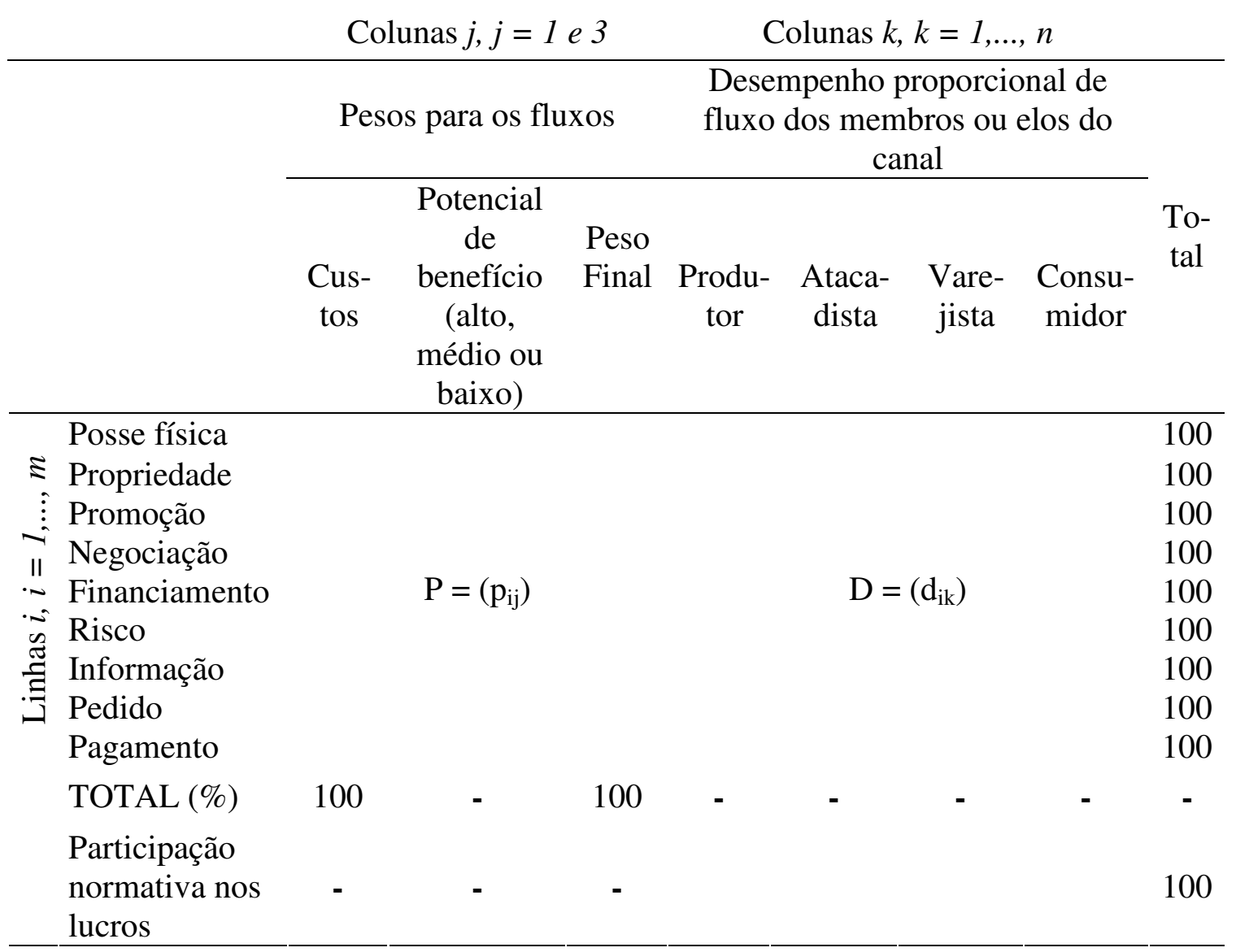

Fonte: adaptado de Coughlan et al. (2002) e Consoli et al. (2004)

Os cruzamentos entre as linhas $i$ e as colunas $j$ e $k$ formarão células de duas matrizes as quais serão denominadas de $\mathrm{P}=\left(\mathrm{p}_{\mathrm{ij}}\right)$ e $\mathrm{D}=\left(\mathrm{d}_{\mathrm{ik}}\right)$ respectivamente.

Os somatórios tanto da coluna "Custos" $(j=1)$ quanto da coluna "Peso final" $(j=3)$ devem ser sempre iguais a $100 \%$. Isto significa dizer que os custos de todos fluxos de marketing devem somar $100 \%$. Assim, a linha "TOTAL" deve sempre ter valor igual a $100 \%$, para $j=1$ e 3 . A eq. (1) expressa analiticamente o texto.

$$
\sum_{i=1}^{m} p_{i 1}=\sum_{i=1}^{m} p_{i 3}=100
$$


Existe ainda a necessidade da ponderação de cada fluxo de canal, pois dependendo do negócio em que o estudo é aplicado, um fluxo é mais importante que outro na agregação de valor. Esta ponderação está representada na coluna "Potencial de benefício" $(j=2)$.

Alto (A), médio (M) ou baixo (B) serão as três ponderações adotadas e devem ter importâncias relativas para o canal definidas numa análise antes da aplicação do modelo. Portanto, esta coluna não recebe variáveis matemáticas e não deve ser contabilizada nos cálculos matriciais.

Analogamente às colunas $j=1 \mathrm{e} 3$, cada linha $i$, na matriz $\mathrm{D}$, deve obrigatoriamente somar $100 \%$, ou seja, cada fluxo de marketing deve ser dividido na sua totalidade entre todos os elos da cadeia. Portanto, na coluna "TOTAL", todas as suas linhas $i$ têm de somar $100 \%$. A eq. (2) resume o texto.

$$
\sum_{k=1}^{n} d_{1 k}=\sum_{k=1}^{n} d_{2 k}=\sum_{k=1}^{n} d_{3 k}=\ldots=\sum_{k=1}^{n} d_{m k}=100
$$

De posse de todos os dados nas matrizes $\mathrm{P}$ e $\mathrm{D}$, o passo seguinte é o tratamento analítico dos números obtidos. Uma média ponderada deve ser calculada para cada elo $k$, cujo resultado deve aparecer na linha "Participação normativa nos lucros", abaixo da matriz D.

Essa média ponderada é feita entre os valores da coluna $j=3$ ("Custo com peso final") e os valores das colunas $k$ ("Desempenho proporcional de fluxo dos membros do canal"), ou seja, para cada elo.

O seu resultado será a proposta de recebimento justo do lucro da cadeia de acordo com o total de custo gerado, aqui representado pela agregação de valor. Por exemplo, para o elo "Produtor" $(k=1)$, a sua participação em agregação de valor será a 
média ponderada dos custos pela sua contribuição de custo para cada fluxo de marketing. A eq. (3) sintetiza tal comportamento.

Participação normativa nos lucros do elo $k=$

$$
=\sum_{i=1}^{m} p_{i 3} \times d_{i k}, \text { para } k=1, \ldots \mathrm{n}
$$

A soma de todos os resultados obtidos na linha da "Participação normativa nos lucros" deve totalizar os $100 \%$, ou seja,

$$
\sum_{k=1}^{n} \sum_{i=1}^{m} p_{i 3} \times d_{i k}=100
$$

Para a obtenção dos dados que preencherão as matrizes $\mathrm{P}$ e D do quadro, são sugeridas duas técnicas: a primeira é a análise ABC (Activity Based Costing), em português Custeio Baseado em Atividades, para cada fluxo. Esta fonte de evidências é classificada como fonte de documentação, segundo terminologia de Yin (2001).

A técnica $\mathrm{ABC}$ é uma ferramenta contábil que faz rateio de custos segundo atividades que geram custos direta ou indiretamente ao produto, extremante útil no rateio quando se trabalha com uma cadeia de valor.

A segunda técnica é a obtenção dos dados pela metodologia Delphi, resultado de análises qualitativas, cujas estimativas são fornecidas por diversos especialistas atuantes num negócio, pela realização de entrevistas. Normalmente é utilizado quando os dados gerenciais, contábeis ou financeiros não estão disponíveis. Esta fonte de evidências é classificada como de entrevistas, segundo Yin (2001).

Em suma, esse quadro tenta descrever como cada elo do canal agrega valor ao produto final por fluxo pré-estabelecido. Como resultado, é possível obter: 
- a verificação de como os custos de determinados fluxos são compartilhados entre os membros de canal;

- a contribuição de cada elo para a criação global de valor do produto;

- a importância de cada um dos fluxos no desempenho total do canal;

- a explicação para o desempenho atual do canal e justificar eventuais mudanças que seus gerentes possam vir a realizar.

Esse modelo possui algumas restrições:

1. foi fundamentado para canais de distribuição, portanto, para serem aplicáveis na integração "para frente";

2. um canal que não possui uma análise de custeio $A B C$ devidamente estruturada torna inviável a aplicação desta técnica quantitativa, o que força o uso de métodos qualitativos, tal como o Delphi;

3. deve ser realizado um estudo completo por canal de distribuição;

4. os fluxos de canal devem ser estruturados de forma minuciosa para refletirem a realidade do canal;

5. a questão do fisco não foi abordada para não distorcer dados gerenciais isentos de análises na busca de otimização fiscal.

Serão assim adotados os métodos do modelo de eficiência proposto para análise de canais de distribuição, assim como será proposta uma adaptação do quadro e dos fluxos de marketing para o caso da gestão da cadeia de suprimentos. Estes fluxos estão presentes na cadeia de valor.

A metodologia Delphi será utilizada para a obtenção dos dados e o preenchimento do quadro no decorrer do estudo de caso. No caso específico, tal metodologia pode ser justificada uma vez que os dados de custos necessários nem sempre são contábeis, portanto, dificilmente mensuráveis ou obtidos no dia-a-dia das empresas. 


\subsection{Estudo de caso}

\subsubsection{Descrição}

Yin (2001) descreve que um estudo de caso é uma boa forma de estratégia de pesquisa abrangente quando o trabalho se propõe a responder o "como" e o "por que" de alguns eventos.

Concomitantemente, o pesquisador não possui controle sobre eventos comportamentais e focaliza a investigação de fenômenos ou acontecimentos contemporâneos dentro do contexto da vida real. A sua investigação empírica busca definir os limites entre os fenômenos e o seu contexto real.

O presente estudo de caso se caracteriza por ser explanatório, na medida que se propõe a fornecer explicações para um conjunto de eventos que podem ser aplicadas em outras situações. $\mathrm{O}$ estudo da cadeia do frango integrada e coordenada verticalmente será o objeto de levantamento dos eventos.

Um ponto importante do seu desenvolvimento é que este estudo de caso será único. Yin (2001) argumenta que um projeto de caso único representa o teste decisivo de uma teoria significativa.

Entretanto, a escolha do caso único não seguiu exatamente este critério, pois o que se pretende, na essência, é validar a proposta de adaptação de uma metodologia para um cenário específico, podendo este ser adaptado e aplicado em outros cenários. Não obstante, ambos os critérios estão relacionados e, de certa forma, são complementares.

$\mathrm{O}$ argumento principal que norteou a escolha de um caso único foi a citação de AveseOvos (2004) ao mostrar que a estrutura de governança do segmento de carnes de frango no Brasil está em torno de $75 \%$ coordenada verticalmente entre os elos dos integrados e os abatedouros. O segundo argumento é a necessidade de se visualizar completamente a distribuição dos custos da cadeia de suprimentos.

Nas seções subseqüentes, serão apresentados os passos realizados na condução do estudo de caso explanatório: i) a metodologia utilizada para busca das 
informações; ii) as aplicações das teorias apresentadas no Capítulo 2; e iii) as adaptações necessárias para a realização do estudo propriamente dito.

A aplicação do estudo de caso no campo (a busca dos dados, preenchimento das tabelas e finalização) foi dimensionada para durar no máximo cinco meses, a contar da data da entrevista realizada na APA em meados de julho de 2004. O objetivo foi finalizar o estudo de caso até o final daquele ano.

\subsubsection{Metodologia Delphi e aplicação no caso da cadeia do frango ${ }^{14}$}

A metodologia Delphi é caracterizada pela sua simplicidade e subjetividade na busca das informações. Basicamente qualitativa, procura antecipar os rumos das pesquisas e propiciar uma reflexão coletiva sobre eventos futuros. Seu uso é eficaz quando há carência ou discordância de dados e quando há pretensão de se estimular a criação de novas idéias para a obtenção dos mesmos (Wright \& Giovinazzo, 2000).

O objetivo do trabalho de pesquisa para o uso da metodologia Delphi deve ser definido antecipadamente, assim como o resultado desejado. As informações são obtidas por especialistas nas áreas demandadas durante a pesquisa. Estas pessoas são contatadas individualmente e a equipe coordenadora deve explicar qual o objetivo do estudo, o que é a metodologia e qual a importância de cada um deles no processo.

Em seguida, as informações ou dados obtidos recebem, na maior parte dos casos, tratamento estatístico básico (como mediana e quartis) e são finalmente reanalisados até a busca do consenso do grupo. Algumas rodadas são sugeridas para a convergência das respostas. Em cada uma, o questionário agrega os resultados da tabulação anterior a fim de possibilitar a posição da resposta do respondente frente às outras respostas.

Três condições básicas são observadas durante a realização do trabalho: (a) o anonimato dos especialistas respondentes na maior parte da condução das entrevistas, principalmente no início, (b) o tratamento estatístico das respostas obtidas se o número

\footnotetext{
${ }^{14}$ A revisão da metodologia Delphi foi baseada no trabalho de Wright \& Giovinazzo (2000)
} 
de respondentes fornecer uma amostra grande o suficiente e (c) o retorno dos resultados compilados do grupo para as reavaliações subseqüentes até o consenso final.

O desenvolvimento no uso da metodologia Delphi é tido como extremamente criativo, pois permite reunir ao mesmo tempo a experiência dos participantes e a estruturação do raciocínio para a formulação do questionário.

O resultado é o uso estruturado do conhecimento coletivo mais bem adaptado a uma realidade ampla e complexa. Uma pessoa, por mais conhecedora dos fatos, acaba por viesar o raciocínio e limitar o escopo do pensamento, daí a necessidade de profissionais especialistas nas mais diversas áreas.

Um questionário é a principal fonte da pesquisa. Ele deve conter todo o escopo necessário e ser o mais objetivo e abrangente possível. A montagem deve seguir um raciocínio lógico e, de preferência, linear, para facilitar o preenchimento.

Com os questionários respondidos realizam-se as análises estatísticas, se necessárias. Na seqüência, iniciam-se as rodadas interativas e iterativas até a finalização por consenso. O questionário utilizado será apresentado no próximo tópico.

A quebra do anonimato prejudica as condições necessárias para que um especialista de renome abandone seu rigor científico e passe a especular sobre o futuro (Wright \& Giovinazzo, 2000).

Entretanto, em alguns casos surge a necessidade desta quebra para continuação do trabalho, uma vez que podem ser realizadas entrevistas ou validações com a equipe toda. Ela deve ser realizada quando o trabalho está próximo de sua validação final, cujos dados não sofrerão mudanças bruscas.

O uso da metodologia Delphi é, portanto, resultado da união do conhecimento empírico de especialistas de algumas áreas, do anonimato deles em grande parte do desenvolvimento do trabalho, da aplicação de diversas rodadas para validar um modelo final e da busca do consenso das informações. 


\subsubsection{Adaptação da cadeia do frango para realização do estudo de caso}

O desenvolvimento desta seção seguirá a estrutura lógica do referencial teórico e, em seguida, os ajustes necessários para aplicação da metodologia proposta, ajustes no modelo e realização do estudo de caso.

A questão relacionada ao melhor alinhamento estratégico para esse tipo de cadeia de suprimentos já foi discutida na seção 3.3.3. Dela foi levantada a necessidade de análise de custos e de indicações de potenciais pontos de otimização a serem analisados na cadeia. Assim, o desenvolvimento tanto do modelo de eficiência quanto da metodologia Delphi, no estudo de caso, serão direcionados para este fim.

Ressalta-se que não haverá separação de produtos e nem de mercados para a realização do estudo de caso, análise esta que será macro para a cadeia do frango.

Antes da aplicação do questionário da metodologia Delphi, foi necessário desenhar a cadeia de suprimentos que mais se adaptasse à teoria proposta. Isto iria fornecer o melhor embasamento na busca das informações.

Para tanto, foram definidos quais elos primários da cadeia, assim como aqueles que poderiam ser agrupados. A cadeia da Figura 16 foi a norteadora do trabalho.

Para a aplicação da metodologia, decidiu-se pela simplificação do desenho da cadeia. A sugestão foi o agrupamento de alguns elos em elos maiores, de acordo com a semelhança das atividades operacionais e cujo reflexo direto na cadeia de valor é praticamente o mesmo. A Figura 19 esquematiza este agrupamento. 


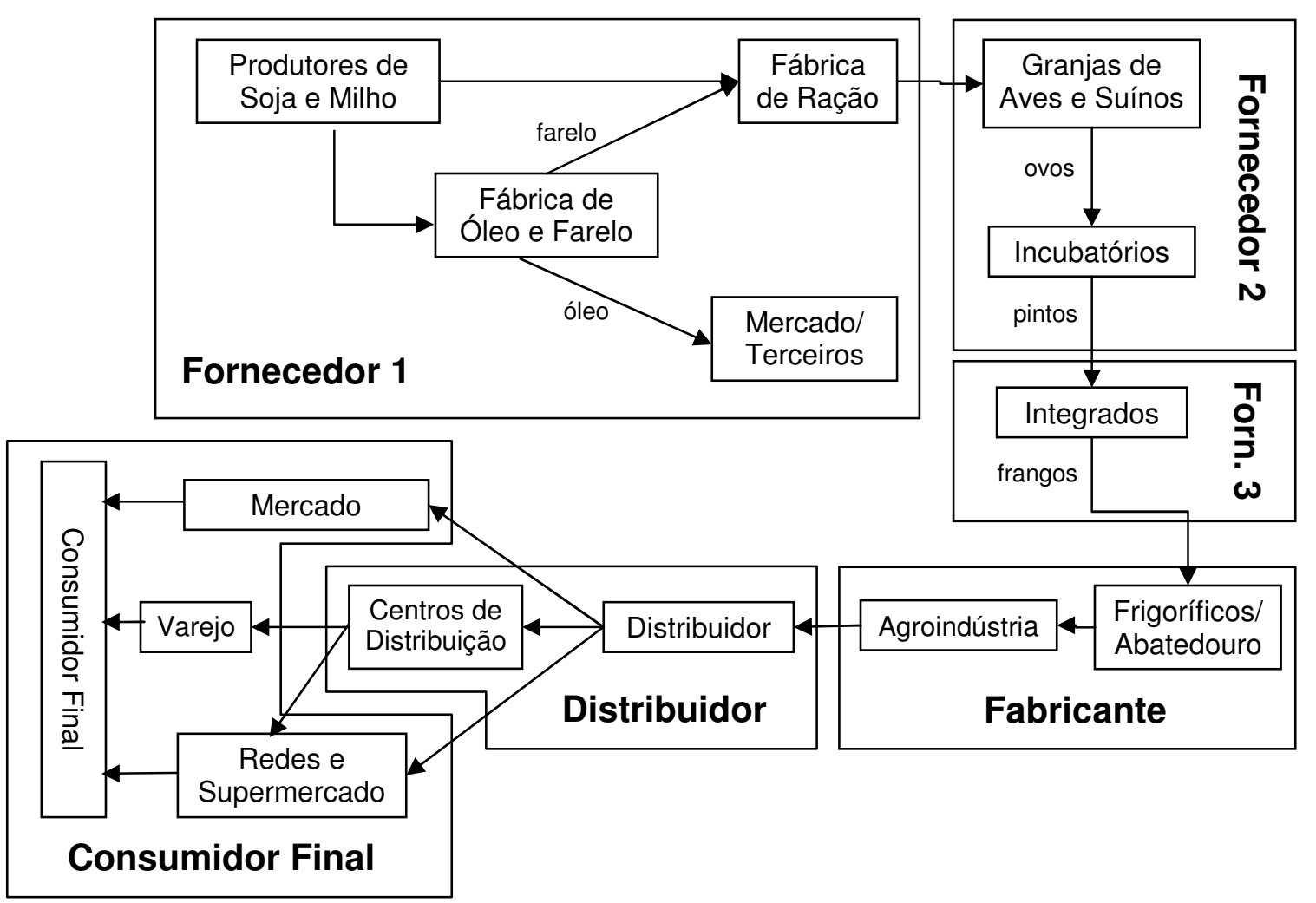

Figura 19 - Agrupamento de elos da cadeia de suprimentos do frango

O elo "Fornecedor 1" (terceiro nível) é composto por todos os elos responsáveis pela fabricação do alimento do frango: os produtores de grãos, as fábricas de ração e de óleo e farelo.

O elo "Fornecedor 2" (segundo nível) envolve os responsáveis pela geração do frango: as granjas e os incubatórios. Deles sairão os pintinhos a serem enviados aos integrados para criação.

O elo "Fornecedor 3" (primeiro nível) inclui os integrados, responsáveis pela criação do pinto até torná-lo frango pronto para o abate.

O elo "Fabricante" é composto pelos responsáveis pelo abate, industrialização da carne e preparação antes do envio para o mercado. Dele sai o produto 
que será consumido. É a união dos abatedouros e a agroindústria de transformação (plantas industriais), sendo o último elo da cadeia que transforma o produto.

O elo "Distribuidor" agrega o próprio distribuidor e os centros de distribuição da cadeia. Deste elo até o último da cadeia começa o chamado canal de distribuição de marketing, por onde o produto segue até chegar ao consumidor final sem qualquer modificação física, ou seja, a agregação de valor é unicamente por meio de atividades de serviços. São os responsáveis pela distribuição do alimento.

O último elo é o "Consumidor Final". A ele foram agregados todos os elos da cadeia que não mais estão sob domínio vertical das empresas nacionais de frango, sendo elos atuantes no mercado. São eles as redes e supermercados, varejistas, mercado externo e consumidor final. Esta estratégia foi adotada porque a obtenção dos dados é extremamente dificultada e foge do foco deste trabalho, de analisar apenas a cadeia integrada e coordenada verticalmente.

O não-agrupamento desses elos em um único poderia inviabilizar a pesquisa, pois a condução do estudo de caso deveria contemplar também entrevistas ao longo dos elos não pertencentes à cadeia integrada verticalmente. Outro motivo é que, no início das pesquisas, constatou-se que estes elos agregam menos custo ao produto se comparados aos demais, o que acabou ratificando o agrupamento.

O passo seguinte foi a definição das funções e das atividades (ou fatoreschave) da cadeia de valor para confecção do questionário. Estas atividades são chamadas de fluxos da cadeia de suprimentos no estudo de caso, pela analogia à nomenclatura do modelo de eficiência.

As quatro áreas empresariais que envolvem a gestão da cadeia de suprimentos integrada verticalmente (logística, produção, marketing e finanças) serão usadas para o estudo da cadeia de valor. Paralelamente, as funções da cadeia de valor para a cadeia de suprimentos, sugeridas na Figura 6 serão também estruturadas de forma a se agruparem nestas áreas. 
O critério adotado foi o de fluxos cruzados em diversas funções, considerados como equivalentes no desenvolvimento do trabalho que pudessem ser direcionados às áreas, unicamente. Assim, a idéia aqui foi unificar estas áreas com as funções da cadeia de valor e agrupar todos os fluxos identificados abaixo delas. Para tanto, estipulou-se o seguinte:

- Logística: deve agregar todos os fluxos relacionados ao transporte, armazenagem física e gestão de pedidos. Estas atividades advêm das funções de operações, distribuição e serviços na cadeia de valor;

- Produção: agrupa os fluxos de transformação física do produto em si. Basicamente estão atreladas às funções operacionais e de recursos humanos voltadas à cadeia de valor;

- Marketing: diversos fluxos desta função da cadeia de valor foram resgatados do modelo de eficiência original. Basicamente são os que respondem pelo canal de distribuição, vendas, comercialização e estoques, e contemplam a maior parte dos custos de transação. $\mathrm{Na}$ cadeia de valor, representa a função de marketing/vendas e eventualmente, alguns fluxos da função de serviços;

- Finanças: na cadeia de valor esta função é de suporte, tendo fluxos em todo o desenvolvimento da cadeia. Por ser uma área da cadeia de suprimentos, ela será abordada aqui juntamente com fluxos de financiamento e risco no negócio.

Essas áreas com seus respectivos fluxos serão avaliados numa adaptação do modelo de eficiência. A seguir, estão apresentadas as maneiras como tais fluxos devem ser analisados e como deve ser a busca pelos dados. Na seqüência, sugere-se um novo quadro adaptado para o estudo de caso.

Ressalte-se aqui que influências sobre a questão fiscal não serão abordadas para evitar quaisquer distorções fora do escopo de otimização gerencial integrada. 
Mesmo sendo um fator analisado como vantagem da integração, a necessidade pela imparcialidade neste ponto é importante para se analisar a eficiência da cadeia no desenvolvimento de suas principais atividades que agreguem valor.

\subsubsection{A especificação dos dados e tabela}

Nas subseções a seguir, cada área da cadeia de suprimentos será apresentada sucintamente, visando o melhor entendimento do modelo. Vale destacar que a especificação dos dados foi compilada em um questionário (semelhante ao que será apresentado a seguir) e validada por um especialista de uma associação, antes da busca dos dados em campo.

Em seguida, para obtenção dos dados, quatro especialistas foram indicados para ajudarem na realização do estudo de caso. Estes especialistas foram sugeridos como sendo um de cada área (logística, produção, marketing/comercial e finanças).

Ao final da descrição de cada área, é sugerida uma pergunta-resumo do que foi exposto. Em seguida, para cada uma das áreas, apresentam-se os fluxos da cadeia de suprimentos, a sua explicação e a questão a ser respondida. Estes fluxos serão agrupados segundo a classificação proposta e será exposta uma tabela final, adaptada do modelo de eficiência.

O importante durante a busca dos dados foi entender que os custos devem ser analisados segundo o elo que "está com" ou que "realiza" o fluxo naquele momento. Este ponto foi por diversas vezes posto em questão durante as reuniões com os especialistas e mereceu destaque no decorrer do estudo de caso.

\subsubsection{Logística}

Os fluxos da cadeia de suprimentos relacionados à área de logística serão basicamente os responsáveis pela movimentação dos produtos, ou seja, administração de materiais, transporte e gestão de pedidos. 
Usada de forma tradicional, a logística aqui vai representar o que as empresas hoje desenvolvem em termos gerenciais. Portanto, segue a pergunta inicial de cada área, seguida das explicações, e a pergunta de cada fluxo, que devem ser respondidas de forma empírica:

Pergunta: como os custos de logística estão distribuídos segundo os elos da cadeia?

- Transporte: representa os fluxos que envolvem transporte de mercadorias, de produtos e de matéria-prima em geral. Quais são os responsáveis na cadeia e como os custos estão repartidos entre os atuantes na cadeia integrada?

- Armazenagem: representa toda a estrutura física necessária para estocagem de materiais. Como esta estrutura e os custos com armazenagem estão distribuídos entre os elos da cadeia integrada?

- Entregas/pedidos: os custos de entregas estão relacionados com a gestão da entrega do pedido ao nível de serviço determinado (prazo e quantidade). Paralelamente, também incorrem os custos de gestão do pedido e nível de serviço determinado. O fluxo da gestão do pedido envolve custos incorridos na administração da necessidade do produto final pelo cliente em cada elo da cadeia. Como os custos de gestão dos pedidos e entregas estão distribuídos na cadeia integrada?

\subsubsection{Produção}

No caso de produção, os custos estão relacionados indiretamente com a produção e modificação direta dos produtos. Tais valores podem ser obtidos por meio do CPV (custo do produto vendido) ou CMV (custo da mercadoria vendida).

Pergunta: como se dividem os custos diretos e indiretos de produção na cadeia? 
- Produto: com a movimentação do produto ao longo dos elos, há um valor agregado em termos de material e transformação. Qual é o custo do material e da transformação que foi agregado para finalizar todo o processo de produção ao longo da cadeia?

- Embalagens: para realização de transporte, armazenagem e entregas, há necessidade de embalagens e acondicionamento dos produtos. Como os custos de embalagem estão distribuídos na cadeia integrada?

- Tecnologia: a cadeia integrada sugere tecnologia de maquinário específica do negócio; além disto, diversas atividades específicas de controle e planejamento são utilizadas para o gerenciamento da produção. Quais os custos de tecnologia para produção entre os elos da cadeia?

- Instalação: as instalações de produção são específicas para cada elo da cadeia e demandam investimentos diretos. A diferença entre tecnologia e instalação é que o primeiro responde pelo maquinário, enquanto o segundo pelas instalações físicas fabris. Como está a distribuição dos custos de instalação física para produção na cadeia?

- Mão-de-Obra: diz respeito ao uso de mão-de-obra direta específica e treinada para produção e gestão do negócio. Qual é a distribuição do custo específico de mão-de-obra direta de produção nos elos da cadeia para o frango?

- Rastreamento: como vantagem da cadeia integrada e de perecíveis, o rastreamento é controlado para garantia da qualidade do produto. De que forma os custos envolvidos com o rastreamento estão distribuídos na cadeia?

\subsubsection{Marketing e comercial}

Os custos de marketing e comerciais são responsáveis diretamente pelo contato com clientes e com o mercado. Foi desenvolvido basicamente pelo que se 
entende por vendas, negociação e gestão dos canais de distribuição. Neste momento não há mais modificação do produto, mas gestão de serviços necessários para o sucesso das distribuições de produtos acabados e vendas. A restrição fica por conta do fluxo de propriedade.

Para o seu dimensionamento em custos, a idéia é verificar qual o custo total de cada fluxo e o quanto cada elo da cadeia de suprimentos é responsável pela sua realização. Este "quanto" será transformado em custo na análise.

Pergunta: quanto cada elo da cadeia realiza dessas atividades e qual a divisão de custos dos fluxos de marketing para a cadeia integrada?

- Propriedade: está relacionada com a propriedade física do material, ou seja, capital de giro. Quando um elo da cadeia assume a titularidade dos bens, ele assume o custo de estoque. $\mathrm{O}$ capital está direcionado ao estoque e, portanto, para diferenciação do fluxo de produção, trabalha-se com o custo de oportunidade do capital de giro. Qual é o custo de oportunidade do estoque de material ao longo dos elos da cadeia?

- Promoção: diretamente relacionado com vendas, pela necessidade de promoção para vender o produto no mercado ou até entre fornecedores, seja qual for o canal. Qual é o impacto de custos da promoção ou qual a promoção necessária em cada elo da cadeia integrada? Neste caso, para a sua determinação é necessário saber "onde" a promoção é mais forte, ou seja, qual o elo que mais realiza a atividade e esta divisão será tida como o custo por elo.

- Negociação: para o processo de vendas, busca de novos mercados e elaboração de contratos, há a necessidade de negociação e realização destes contratos para a execução do negócio. Tal processo envolve tempo e, em diversos momentos, contratos formais. Normalmente, estes custos são mais significativos para produtos de exportação e 
pouco significativos para contratos de longo prazo (relacionamento duradouro). Qual é o custo de negociação em cada elo da cadeia?

- Informação: necessidade de informação para gerenciamento da demanda e oferta durante o processo de planejamento, controle e execução da produção. A busca da informação se confunde por diversas vezes com o custo da Tecnologia da Informação (TI). A diferença é a necessidade da informação, não levando em consideração a estrutura necessária para isto. Qual é o custo da informação para cada elo da cadeia?

- Pedido: relacionado com os custos de gestão do pedido e nível de serviço determinado. Qual é o custo com gestão do pedido entre os elos da cadeia de suprimentos integrada?

- Pagamento: este fluxo está relacionado com o fluxo de pagamento dos pedidos, ou seja, o fluxo do risco financeiro de contas a pagar e receber. Sendo assim, agrega o risco relacionado com os pagamentos não efetuados e o impacto na necessidade de estrutura interna para recebimento de dívidas. Para pagamento de clientes e fornecedores, qual é o impacto do custo distribuído na cadeia integrada?

\subsubsection{Finanças}

Os fluxos de finanças representam a gestão do capital e do risco financeiros a serem distribuídos e recebidos entre os elos da cadeia.

Pergunta: qual é a divisão dos custos financeiros para a cadeia segundo os seguintes fluxos?

- Financiamento: neste fluxo, analisam-se os custos de oportunidade juntamente com os custos de crédito do negócio. Por diversas vezes, a entrega é realizada antes do pagamento, o que faz com que o vendedor assuma um custo financeiro (capital utilizado para uma atividade 
alternativa de investimento). Pode ocorrer, também, o caso de o comprador pagar antes do recebimento da mercadoria. Nesta análise, como a visão é da cadeia integrada e não a do cliente, se o segundo caso ocorrer, o custo de financiamento deve ser nulo no canal. Em termos de custo de oportunidade, qual é o custo de financiamento para cada elo da cadeia?

- Agronegócio: são particularidades do risco do negócio de frango envolvido com as externalidades de mercado. $\mathrm{O}$ investimento no negócio frango pode trazer alguns riscos específicos, cuja necessidade de gestão seja própria. Como o custo do risco de mercado no negócio frango está dividido entre os elos da cadeia?

De posse dessas descrições, será sugerido um quadro que unifica todas as áreas com seus respectivos fluxos.

Como o estudo vai contemplar basicamente análise de custos, focado principalmente nos elos produtores, a coluna de "participação de agregação de valor" será realocada no final da tabela apenas como indicativo de possíveis pontos de agregação de valor ponderados nos fluxos.

Assim, a coluna "peso final” será suprimida. Já a última linha "participação normativa na agregação de valor" será renomeada como "participação normativa na agregação de custos" e também haverá a supressão da linha "Total”, pois não haverá serventia nessa nova adaptação.

A Tabela 8 mostra como será a tabulação dos dados a serem obtidos e trabalhados. 
Tabela 8. Modelo de eficiência adaptado para cadeia de suprimentos do frango integrada verticalmente

\begin{tabular}{|c|c|c|c|c|c|c|c|c|c|}
\hline & \multirow{3}{*}{ Custo (\%) } & \multicolumn{6}{|c|}{ Desempenho proporcional dos fluxos dos elos da cadeia } & \multirow{3}{*}{$\begin{array}{c}\text { TOTAL } \\
(\%)\end{array}$} & \multirow{3}{*}{$\begin{array}{c}\text { Potencial de } \\
\text { agregação } \\
\text { de valor }\end{array}$} \\
\hline & & \multicolumn{3}{|c|}{ Fornecedores } & \multirow{2}{*}{ Fabricante } & \multirow{2}{*}{ Distribuidor } & \multirow{2}{*}{$\begin{array}{l}\text { Varejista/ } \\
\text { Consumidor } \\
\text { final }\end{array}$} & & \\
\hline & & 1 & 2 & 3 & & & & & \\
\hline \multicolumn{10}{|l|}{ Logística } \\
\hline \multicolumn{10}{|l|}{$\begin{array}{l}\text { Transporte } \\
\text { Armazenagem } \\
\text { Entrega/Pedido }\end{array}$} \\
\hline \multicolumn{10}{|l|}{ Produção } \\
\hline \multicolumn{10}{|l|}{$\begin{array}{l}\text { Produtos } \\
\text { Embalagem } \\
\text { Tecnologia } \\
\text { Instalação } \\
\text { Mão-de-Obra } \\
\text { Rastreamento }\end{array}$} \\
\hline \multicolumn{10}{|l|}{ Marketing e Comercial } \\
\hline $\begin{array}{l}\text { Propriedade } \\
\text { Promoção } \\
\text { Negociação } \\
\text { Informação } \\
\text { Pagamento }\end{array}$ & & & & & & & & & \\
\hline \multicolumn{10}{|l|}{ Finanças } \\
\hline \multicolumn{10}{|l|}{$\begin{array}{l}\text { Financiamento } \\
\text { Agronegócio }\end{array}$} \\
\hline $\begin{array}{l}\text { Participação normativa } \\
\text { na agregação de custos }\end{array}$ & & & & & & & & & \\
\hline
\end{tabular}

Em alusão à explicação do modelo de eficiência descrita na seção 4.1, pela Tabela 7, a matriz P se resume apenas à coluna "Custos". A matriz D ocupa quase toda a tabela e está representada pelas divisões da coluna "Desempenho proporcional de fluxo dos elos da cadeia".

Destaca-se que esse modelo para análise dos custos foi validado com os entrevistadores e com especialistas da área avícola, via associação, no período de julho a agosto de 2004, antes de sua aplicação para o estudo de caso. 


\subsubsection{Obtenção dos dados}

O primeiro contato com um especialista de uma associação foi durante a entrevista realizada na APA, em meados de julho de 2004. Para este encontro, toda a metodologia e o escopo da tabela proposta estavam prontos.

Sua contribuição disse respeito principalmente à obtenção de dados estatísticos do mercado de aves e indicações de pontos importantes a serem observados durante a condução do estudo de caso em uma empresa do setor.

Ademais, esse especialista não conseguiu fornecer dados minuciosos necessários para o preenchimento da tabela, pois estão distantes do dia-a-dia operacional das empresas. Portanto, houve a primeira validação do plano do estudo de caso.

O segundo contato ocorreu numa empresa representativa do setor avícola, que atua no Brasil. O intuito desta entrevista foi o uso do conhecimento prático para a validação final do modelo proposto, sua aplicação e condução do estudo de caso.

A abordagem necessária para o desenvolvimento do estudo de caso na empresa avícola em questão só foi possível devido aos contatos mantidos ao longo da vida acadêmica e profissional. Trata-se de profissionais que, atualmente, ocupam diversos cargos importantes nestas duas áreas. Assim, pessoas-chave foram acionadas para receberem e conduzirem o trabalho.

Para obtenção dos dados, foram propostas reuniões com especialistas de cada uma das áreas envolvidas (logística, finanças, marketing e produção) durante o período de julho a novembro de 2004.

Para cada área específica foi indicado um profissional do assunto, totalizando quatro. Os profissionais foram inicialmente abordados em reuniões individuais.

Foi apresentada a eles a metodologia Delphi, a ser utilizada no levantamento dos dados, explicada a forma de preenchimento do quadro do modelo de eficiência adaptado via questionário, assim como confirmados os objetivos do trabalho. Ao todo, 
foi necessário um período de seis meses e dez reuniões para a realização e validação do estudo de caso.

A Figura 20 mostra esquematicamente um fluxograma dos passos seguidos para a obtenção dos dados.

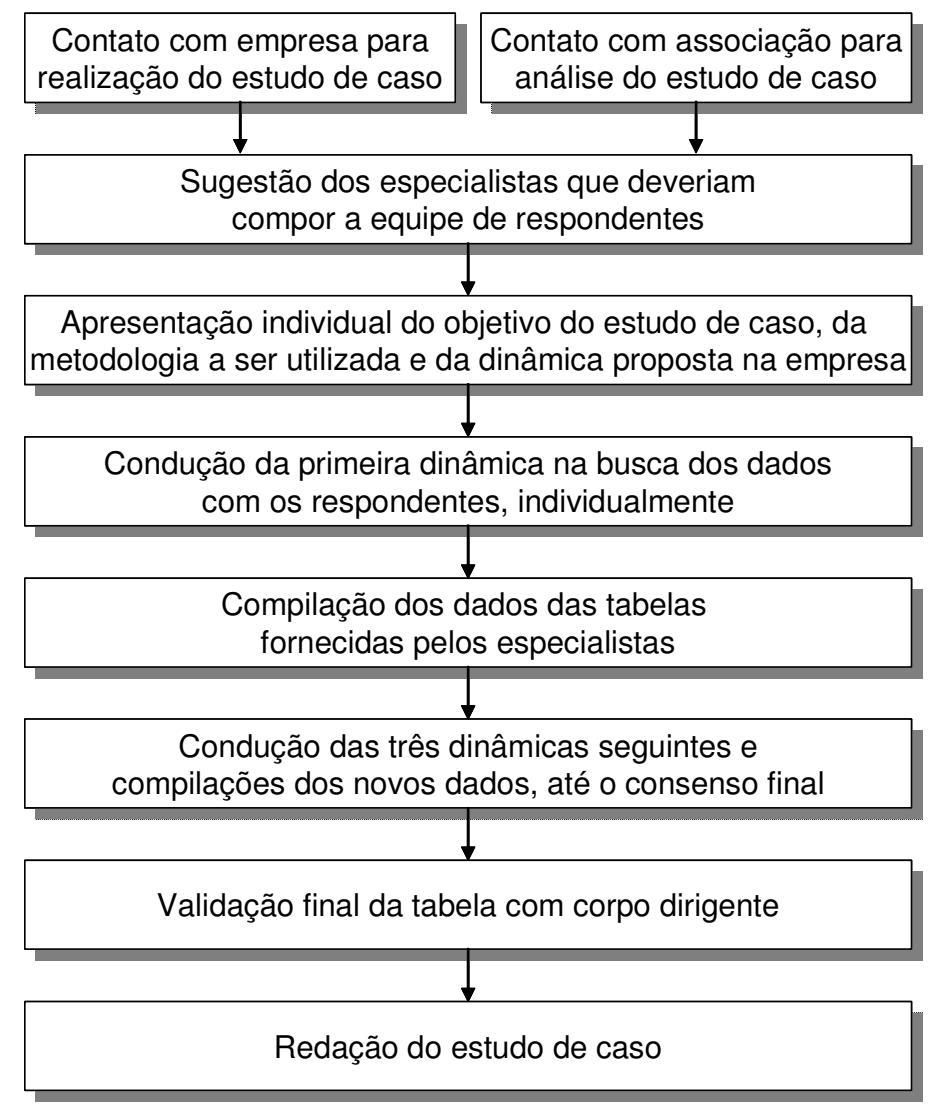

Figura 20 - Passos seguidos no desenvolvimento do estudo de caso

As primeiras reuniões na empresa foram necessárias para explicar o contexto do trabalho, a metodologia Delphi e a necessidade dos dados. Inicialmente, o estudo de caso contou com quatro especialistas. Percebeu-se que havia uma certa dificuldade para se entender o que era necessário e como eles deveriam conduzir a busca dos dados. Isto foi logo sanado com um exemplo mostrado, realizado por Consoli et al. (2004) aplicado num canal de distribuição para cadeia de iogurtes. 
Os participantes foram convocados a fornecer seus pareceres segundo a experiência adquirida no meio empresarial e no ramo do trabalho, ou seja, cadeia do frango. Esta dinâmica foi, num primeiro momento, conduzida em quatro reuniões individuais com os respondentes (especialistas).

Em seguida, os especialistas forneceram uma primeira versão de suas análises, segundo metodologia própria na obtenção dos dados. Vale ressaltar aqui que a busca de dados é subjetiva, uma vez que a experiência e o convívio cotidiano com o negócio desenvolve visões e posturas do dia-a-dia de forma diferenciada. Desta forma, alguns dados trouxeram os vieses da sua área de trabalho.

Os primeiros dados analisados foram os da coluna "Custo", tendo em vista cada fluxo da cadeia e sua participação no total. A análise do potencial de agregação de valor veio por conseguinte, na coluna "Potencial de agregação de valor", à direita da tabela. $\mathrm{O}$ consenso estipulou que $\mathrm{A}=$ alto, $\mathrm{M}=$ médio e $\mathrm{B}=$ baixo para verificar $\mathrm{o}$ potencial de agregação de valor de um fluxo em relação a outro.

Coughlan et al. (2002) sugerem que os valores acrescidos ou diminuídos desses potenciais devem ser discutidos com os especialistas e o consenso indica quanto cada um deve ser. Na aplicação em canais de distribuição, a modificação é realizada pela ponderação da coluna "Custos" pela coluna de "Potencial de agregação de valor".

Neste estudo de caso, como serão trabalhados dados de custos, tal análise não será realizada.

O segundo passo durante a primeira entrevista foi trabalhar as linhas da Tabela 8, ou seja, os fluxos da cadeia em si, juntamente com as colunas de "Desempenho proporcional de fluxo dos elos da cadeia". Cada especialista trouxe a sua percepção da cadeia até o preenchimento completo, individualmente. Este passo foi realizado em duas entrevistas com cada um dos especialistas.

Ao final da primeira rodada de entrevistas com os quatro especialistas, já se possuía quatro tabelas preenchidas parcialmente. Elas não estavam totalmente 
preenchidas porque os profissionais focaram nos dados das suas respectivas áreas de atuação.

A tabela compilada com os primeiros dados recebidos mostrou que estes apresentavam entre si muitas semelhanças. Apenas fluxos de alguns elos necessitavam reavaliações. Os dados foram analisados e postos numa mesma planilha e, para aqueles que estavam muito discrepantes, houve a necessidade de nova análise. Já os que estavam muito próximos, mas ainda diferentes, foram deixados para um segundo momento.

Dos quatro especialistas contatados inicialmente na empresa, dois seguiram até o final. A tarefa de busca das informações e dos dados, análise e preenchimento demandam tempo, esforço e dedicação, nem sempre possíveis para todos. Além disto, a atividade não é remunerada e o usufruto dos dados é diretamente para o presente estudo de caso.

O desfalque ocorreu durante a busca dos dados no preenchimento da tabela, entre a primeira e a segunda rodada de entrevistas. Os dados destes especialistas foram fornecidos durante as reuniões individuais ao longo do desenvolvimento do estudo de caso. Portanto, já se tinha posse das grandezas dos números a serem analisados na finalização do estudo.

Percebeu-se que os remanescentes tinham conhecimento o suficiente da cadeia toda e do negócio frango, o que permitiu a continuidade da condução do trabalho. Dos dois especialistas que seguiram até o fim, um era da área financeira - atuava no planejamento estratégico e possuía claramente experiência e visão integrada tanto de finanças quanto de marketing/comercial.

O outro era de logística e possuía bons conhecimentos em dados da produção, pois desenvolvia estreitas relações com esta área. Portanto, as quatro áreas analisadas continuavam tendo representantes.

Como já havia alguns dados em mãos, resultado das primeiras entrevistas realizadas com os especialistas, não foram detectados impactos significativos que prejudicassem a condução e a qualidade do estudo com os dois especialistas 
remanescentes. Assim, decidiu-se por continuar o trabalho nestas circunstâncias. O foco seria validar todos os números e atingir o consenso.

A segunda rodada de entrevistas, uma com cada especialista, foi realizada para mostrar, comentar e realizar o primeiro ajuste da compilação dos dados obtidos durante a primeira rodada.

As entrevistas foram realizadas individualmente e, a partir deste momento, já se possuía duas tabelas completas com dados muito próximos do final.

As reuniões seguintes tiveram como objetivo avaliar e validar os dados que ainda não estavam coerentes entre si. Para estes encontros (o terceiro e o quarto), foi necessário reunir as equipes dos dois especialistas contatados, que acompanharam o caso até o fim para atingir o consenso. Naquele momento, o anonimato não era mais requerido.

Essas duas últimas reuniões foram mais rápidas devido ao tempo demandado e à disponibilidade dos profissionais. Além disto, percebia-se um certo desgaste da equipe, o que demandava mais objetividade e finalização do processo. O que se focou nestas reuniões foram os ajustes finos para finalização dos dados da tabela.

Toda a dinâmica, desde o início da apresentação até o seu fechamento, foi realizada em oito encontros com os especialistas (seis com cada um deles e duas em conjunto), divididas em quatro rodadas.

Em seguida realizaram-se duas apresentações individualmente com dois gerentes, para validação final dos resultados. Ao todo, dez reuniões foram necessárias. Toda a dinâmica durou cerca de três meses e meio, devido à dificuldade das agendas dos profissionais.

Tanto as respostas dos profissionais quanto o tempo demandado ocorreram dentro do previsto, não havendo qualquer necessidade de interferências externas ou aceleração do processo.

O capítulo seguinte apresenta os resultados obtidos e analisa o estudo de caso, além de trazer alguns cenários para indicação de propostas futuras. 


\section{RESULTADOS}

\subsection{Apresentação}

Os dados tabulados e os resultados dos cálculos do estudo de caso estão apresentados na Tabela 9.

Tabela 9. Resultados do estudo de caso

\begin{tabular}{|c|c|c|c|c|c|c|c|c|c|}
\hline & \multirow{3}{*}{ Custo (\%) } & \multicolumn{6}{|c|}{ Desempenho proporcional de fluxo dos elos da cadeia (\%) } & \multirow{3}{*}{$\begin{array}{c}\text { TOTAL } \\
(\%)\end{array}$} & \multirow{3}{*}{$\begin{array}{c}\text { Potencial de } \\
\text { agregação } \\
\text { de valor }\end{array}$} \\
\hline & & \multicolumn{3}{|c|}{ Fornecedores } & \multirow{2}{*}{ Fabricante } & \multirow{2}{*}{ Distribuidor } & \multirow{2}{*}{$\begin{array}{c}\text { Varejista/ } \\
\text { Consumidor } \\
\text { final }\end{array}$} & & \\
\hline & & 1 & 2 & 3 & & & & & \\
\hline Logística & 10,0 & 0,2 & 0,2 & 0,2 & 5,2 & 3,8 & 0,5 & 10,0 & \\
\hline $\begin{array}{l}\text { Transporte } \\
\text { Armazenagem } \\
\text { Entrega/Pedido }\end{array}$ & $\begin{array}{l}7,5 \\
1,0 \\
1,5\end{array}$ & $\begin{array}{l}2,0 \\
5,0 \\
1,0\end{array}$ & $\begin{array}{l}2,0 \\
1,0\end{array}$ & $\begin{array}{l}2,0 \\
1,0\end{array}$ & $\begin{array}{l}56,0 \\
12,0 \\
57,0\end{array}$ & $\begin{array}{l}38,0 \\
36,0 \\
40,0\end{array}$ & 47,0 & $\begin{array}{l}100,0 \\
100,0 \\
100,0\end{array}$ & $\begin{array}{l}B \\
M \\
A\end{array}$ \\
\hline Produção & 70,0 & 18,5 & 4,2 & 6,3 & 41,0 & 0,0 & 0,1 & 70,0 & \\
\hline $\begin{array}{l}\text { Produtos } \\
\text { Embalagem } \\
\text { Tecnologia } \\
\text { Instalação } \\
\text { Mão-de-Obra } \\
\text { Rastreamento }\end{array}$ & $\begin{array}{l}45,5 \\
5,6 \\
5,6 \\
3,5 \\
7,7 \\
2,1\end{array}$ & $\begin{array}{c}35,0 \\
\\
20,0 \\
15,0 \\
6,0 \\
20,0\end{array}$ & $\begin{array}{c}5,0 \\
\\
15,0 \\
5,0 \\
3,0 \\
30,0\end{array}$ & $\begin{array}{c}10,0 \\
15,0 \\
1,0 \\
40,0\end{array}$ & $\begin{array}{c}50,0 \\
100,0 \\
50,0 \\
80,0 \\
90,0 \\
4,0\end{array}$ & 2,0 & 4,0 & $\begin{array}{l}100,0 \\
100,0 \\
100,0 \\
100,0 \\
100,0 \\
100,0\end{array}$ & $\begin{array}{l}A \\
M \\
A \\
M \\
B \\
M\end{array}$ \\
\hline Marketing e Comercial & 17,0 & 1,3 & 2,6 & 2,9 & 5,3 & 3,0 & 2,0 & 17,0 & \\
\hline $\begin{array}{l}\text { Propriedade } \\
\text { Promoção } \\
\text { Negociação } \\
\text { Informação } \\
\text { Pagamento }\end{array}$ & $\begin{array}{l}8,5 \\
2,0 \\
3,1 \\
2,7 \\
0,7\end{array}$ & 15,0 & 30,0 & $\begin{array}{l}30,0 \\
10,0\end{array}$ & $\begin{array}{c}8,0 \\
10,0 \\
70,0 \\
80,0 \\
15,0\end{array}$ & $\begin{array}{l}12,0 \\
45,0 \\
\\
20,0 \\
75,0\end{array}$ & $\begin{array}{l}5,0 \\
45,0 \\
20,0 \\
\\
10,0\end{array}$ & $\begin{array}{l}100,0 \\
100,0 \\
100,0 \\
100,0 \\
100,0\end{array}$ & $\begin{array}{l}M \\
B \\
B \\
A \\
M\end{array}$ \\
\hline Finanças & 3,0 & 0,9 & 0,3 & 0,9 & 0,4 & 0,3 & 0,2 & 3,0 & \\
\hline $\begin{array}{l}\text { Financiamento } \\
\text { Agronegócio }\end{array}$ & $\begin{array}{l}2,7 \\
0,3\end{array}$ & $\begin{array}{l}30,0 \\
25,0\end{array}$ & $\begin{array}{l}10,0 \\
25,0\end{array}$ & $\begin{array}{l}30,0 \\
35,0\end{array}$ & $\begin{array}{l}14,0 \\
5,0\end{array}$ & $\begin{array}{l}10,0 \\
5,0\end{array}$ & $\begin{array}{l}6,0 \\
5,0\end{array}$ & $\begin{array}{l}100,0 \\
100,0\end{array}$ & $\begin{array}{l}M \\
M\end{array}$ \\
\hline $\begin{array}{l}\text { Participação normativa } \\
\text { na agregação de custos }\end{array}$ & - & $20,8 \%$ & $7,2 \%$ & $10,3 \%$ & $51,9 \%$ & $7,1 \%$ & $2,7 \%$ & $100,0 \%$ & - \\
\hline
\end{tabular}

Fonte: dados da pesquisa

Os espaços em branco na Tabela 9 são indicativos de que o valor do fluxo é nulo para aquele elo. 
Para facilitar o entendimento dos cálculos, indicados na seção 4.1, alguns casos derivados da Tabela 9 serão descritos e explorados ao longo do texto. Em seguida, serão desenvolvidas a análise dos resultados e a exploração de cenários.

É importante salientar que as linhas com tabulação espaçada (logística, produção, marketing e comercial e finanças) são as áreas e não os fluxos. Elas agrupam os valores dos custos para os seus respectivos fluxos e serão discutidos na seqüência. Logo, segundo a eq. (1), tem-se:

$$
\begin{aligned}
\operatorname{TOTAL}(\text { Custo }) & =\sum_{i=1}^{16} p_{i 1}=7,5+1,0+1,5+45,5+5,6+5,6+3,5+7,7+ \\
& +2,1+8,5+2,0+3,1+2,7+0,7+2,7+0,3=100,0
\end{aligned}
$$

As quatro áreas agrupam o somatório dos seus respectivos fluxos. Assim, o transporte, a armazenagem e a entrega/pedido são os fluxos da área de logística que, somados, representam $10 \%(7,5+1,0+1,5)$. Segue o mesmo para as outras três áreas, sendo que a de produção agrega $70 \%$ dos custos, o marketing/comercial $17 \%$ e, finanças, $3 \%$.

O passo seguinte é o preenchimento da coluna "Potencial de agregação de valor". Cada fluxo recebe um potencial de agregação de valor que resulta no dado final a ser analisado. Acompanhando o exemplo para o fluxo de transporte, decidiu-se durante as reuniões que ele tem um baixo potencial de agregação de valor, se comparados a outros. Foi, então, atribuído o peso "B" e assim por diante para todos os fluxos.

Essa análise não é tão importante quanto a análise original do modelo de eficiência, pois neste estudo de caso trabalha-se mais focado em custos, mesmo que estes representem também parte da agregação de valor. 
Na seqüência vem a explicação pela matriz D. Os dados da coluna "Custos" são aqueles que devem ser divididos entre todos os elos da cadeia do frango. Novamente, as áreas receberão tratamento diferenciado.

Para exemplificar um caso de divisão dos valores dos fluxos entre os elos, tome-se o caso do fluxo do transporte, em que a divisão ficou da seguinte forma: $2 \%$ para o fornecedor 1; $2 \%$ para o fornecedor $2 ; 2 \%$ para o fornecedor $3 ; 56 \%$ para o fabricante; e $38 \%$ para o distribuidor. O último elo (varejista/consumidor final) não agrega custo para a cadeia neste fluxo. Percebe-se que a soma desta repartição é 100\%, indicados na coluna “Total”. Segundo a eq. (2), tem-se:

$$
\sum_{k=1}^{6} d_{1 k}=2,0+2,0+2,0+56,0+38,0+0,0=100
$$

Esse raciocínio é aplicado em todos os fluxos e em todos os elos da cadeia. Até este ponto, praticamente todos os dados da Tabela 9 foram obtidos das rodadas pela metodologia Delphi. Daqui para frente, os resultados virão de cálculos a partir dos dados do consenso.

De posse de todos os dados de custos para os fluxos da cadeia de suprimentos preenchidos nos elos, o passo seguinte é a verificação de quanto cada área agrega de custos em cada um deles. Esta análise não foi descrita no modelo de eficiência, pois, como sabido, é uma adaptação da proposta de tal modelo.

A divisão, nesse caso, é um pouco diferente das demais. O total de custo que cada área agrega à cadeia será dividido entre cada um dos elos, pela ponderação dos custos dos seus fluxos com a respectiva participação do elo. Por exemplo: a área de logística agrega $10 \%$ de custo para a cadeia. A idéia é calcular o quanto cada um dos elos representa no total. Ao analisar apenas o caso para o fornecedor 1, a ponderação será a seguinte, todos em valores percentuais:

$$
(7,5 \times 2,0)+(1,0 \times 5,0)+(1,5 \times 1,0)=0,2
$$


Isso significa dizer que os custos logísticos do fornecedor 1 contribuem com $0,2 \%$ para os custos totais da cadeia de suprimentos. Os demais 9,8\% (10\% - 0,2\%) estão repartidos entre os demais elos da cadeia, seguindo o mesmo raciocínio..

Analogamente, os custos de produção do fornecedor 1 contribuem com 18,5\% de todos os custos da cadeia e assim sucessivamente. Esta análise é relevante para elencar as principais áreas que agregam custo nos respectivos elos da cadeia.

De posse dos valores preenchidos com os dados, calcula-se o quanto cada elo agrega de custo (ou de valor) à cadeia do frango. $\mathrm{O}$ resultado é indicado na linha "Participação normativa na agregação de custo".

Essa conta pode ser realizada de duas formas: somando-se os valores calculados de cada área para cada elo ou fazendo-se a ponderação entre o "Custo" e os elos, a partir da eq. (3).

Por exemplo, no caso do elo "fornecedor 1", o cálculo de sua agregação de valor é a soma dos valores de cada área indicados para esse elo, chegando-se a 20,8\%, isto é:

$$
\begin{aligned}
& 0,2+18,5+1,3+0,9=20,8 \% \\
& \text { ou pela ponderação: } \\
& (7,5 \times 2,0)+(1,0 \times 5,0)+(1,5 \times 1,0)+(45,5 \times 35,0)+(5,6 \times 0,0)+(5,6 \times \\
& 20,0)+(3,5 \times 15,0)+(7,7 \times 6,0)+(2,1 \times 20,0)+(8,5 \times 15,0)+(2,0 \times 0,0)+(3,1 \times 0,0) \\
& +(2,7 \times 0,0)+(0,7 \times 0,0)+(2,7 \times 30,0)+(0,3 \times 25,0)=20,8 \%
\end{aligned}
$$

Portanto, 20,8\% é o total que o fornecedor 1 agrega de custo para a cadeia integrada verticalmente. Isto indica que, na teoria, este elo deveria receber no mínimo $20,8 \%$ dos lucros da cadeia. Da mesma forma, todos os elos seguem tal lógica de cálculo, cujo resultado está indicado na última linha da Tabela 9. A soma total de quanto cada elo agrega deve ser sempre 100\%, segundo a eq. (4). Assim:

$$
20,8+7,2+10,3+51,9+7,1+2,7=100 \%
$$




\subsection{Análise dos resultados}

A análise da Tabela 9, que apresenta basicamente o modelo de eficiência aplicado ao caso "para trás" numa cadeia integrada verticalmente, sugere pontos a serem considerados na tomada de decisões e para as melhorias do gerenciamento estratégicotático.

Não são propostas de novas formas de administração de custos, mas uma fotografia do cenário atual da divisão dos mesmos, assim como potenciais focos de forma unificada, uma vez que a integração leva a internalizar diversos custos dificilmente quantificáveis, como os de transação. Este foi o primeiro ponto analisado.

É de se notar que as informações agregadas e refletidas em todos os elos da cadeia ainda não eram unificadas, o que facilita a análise dos custos em todos os segmentos da empresa integrada e coordenada verticalmente.

Ao mesmo tempo, uma primeira leitura da tabela costuma trazer desconforto em relação a alguns números que, por vezes (como os de produção) não refletem exatamente os valores contábeis calculados no dia-a-dia, mas sim uma aproximação.

Pela lógica, não deveriam mesmo, por dois motivos: o primeiro é a busca dos dados pelo conhecimento tácito dos entrevistados. Segundo pela a existência dos custos de transação, dificilmente mensuráveis, que modificam os números finais por diversas razões já apresentadas. Mas o que se procura é a ordem de grandeza dos números.

Todavia, eles não devem ser tão discrepantes a ponto de assumirem importâncias opostas. Além disto, dependendo dos fluxos da cadeia pré-estipulados e da área em que eles forem subalocados, o resultado pode ser diferenciado. Este ponto sugere a criação de cenários para se verificar o impacto de tipo de mudança, os quais serão apresentados na próxima seção.

Os resultados da planilha proposta, analisados neste trabalho, condiziam com a realidade contábil da empresa. Há de se lembrar que este método oferece uma 
aproximação da realidade, porém não os números exatos, que foram obtidos a partir da visão holística do elo gestor da cadeia, no caso, o fabricante.

O primeiro objetivo de se analisar a cadeia de uma forma unificada foi atingido, isto é, as decisões conjuntas podem ser tomadas, além de possibilitar apreciação do impacto global destas decisões.

A análise é iniciada pela linha da "Participação normativa na agregação de custos", a última da Tabela 9, principal resultado do modelo proposto.

O que se obtém é o total de geração de custos, repartido entre os elos da cadeia integrada verticalmente, indicando a possível parcela mínima justa dos lucros que cada um deveria reter.

Mesmo que haja um potencial ganho em divisões desiguais pelo benefício fiscal, o modelo não contemplou esta análise, devido também à sua complexidade. Como não se pretende estudar o caso de indicações de ganhos de fisco, mas sim de gestão da cadeia de suprimentos, o mesmo modelo pode ser usado para ajudar na tomada de decisão neste escopo.

Outro ponto que será apontado como restrição do modelo é a agregação de valor propriamente dita. Como o estudo de caso não se preocupou em dividir o trabalho por produto, mas sim analisar o desempenho conjunto de todos os produtos, esse resultado mostra o desempenho dos elos segundo uma média.

Entretanto, é sabido que cada produto (ou serviço) é diferente e, dependendo do valor agregado, o preço aumenta para o cliente. Este aumento deve ser refletido diretamente no lucro do elo que o gerou.

A divisão da participação nos custos neste trabalho está clara, sendo que o principal elo na agregação de custos da cadeia é o fabricante (com 51,9\%), seguido do fornecedor 1 (com 20,8\%), fornecedor $3(10,3 \%)$, fornecedor 2 (7,2\%), distribuidor $(7,1 \%)$ e por fim o varejista/consumidor final $(2,7 \%)$.

Para melhor ilustração e visualização desses dados, a Figura 21 mostra graficamente a cadeia e seus respectivos valores. 


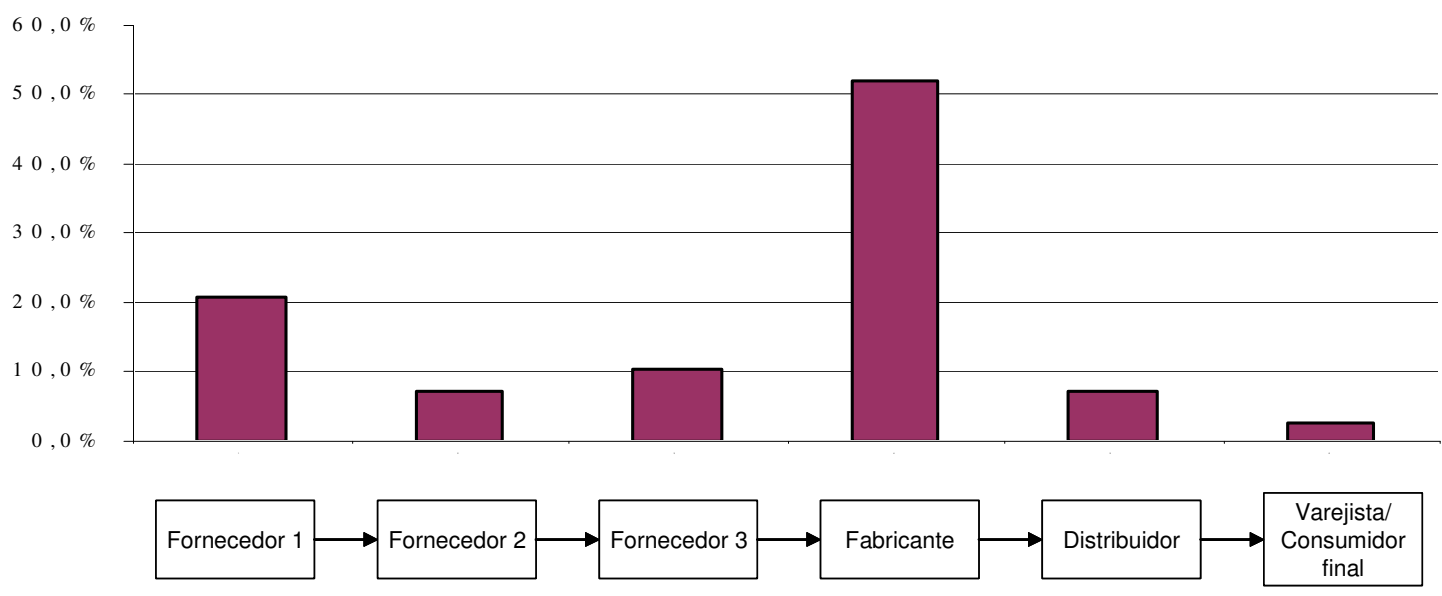

Figura 21 - Participação de cada elo nos custos da cadeia do frango

Esses valores indicam a magnitude da divisão, mas não são exatos, por não serem medidos e sim obtidos por consenso. A importância do fabricante já tinha sido indicada, uma vez que é o principal elo e o que gerencia toda a cadeia.

Muitos custos estão sob o seu domínio, por exemplo, os de transporte, da instalação, da embalagem, da mão-de-obra, de negociação, legais, dentre outros, que são utilizados por todos os elos, mas foram indicados como pertencentes aos gastos do fabricante.

A análise desse elo está de acordo com as indicações de ABEF (2004) sobre o que o integrador (aqui contemplado pelo elo fabricante) oferece à cadeia, especialmente na relação com o elo fornecedor 3 .

Portanto, os dados indicaram a magnitude dessa importância e quais os principais pontos passíveis de serem analisados.

À esquerda do fabricante, ou seja, nos elos dos fornecedores, percebe-se que estes respondem por aproximadamente um terço de todo o valor agregado. Destaque para o fornecedor 1 (o responsável pelo fornecimento da alimentação dos animais), o segundo elo que mais contribui para agregação de valor na cadeia, contabilizando algo em torno de $21 \%$. 
Daí a preocupação com a oferta de grãos e a importância desses fornecedores para sucesso da cadeia. Obviamente a oferta de ração é condição sine-quanon de sustentação desta cadeia, pois a sua ausência interrompe as atividades.

Esse ponto é relevante e já havia sido citado por Canever et al. (1997), Favaret-Filho et al. (1998) e Saboya (2001), sendo que diversas empresas atuantes no setor também tomam suas decisões sobre alocação de novas plantas com olhos na proximidade e na garantia de oferta de grãos para a cadeia.

Portanto, a magnitude do valor dos custos para a cadeia, a quantidade demandada (frequiência das transações) e a garantia de qualidade da ração balanceada para o rastreamento da carne vendida (especificidade do ativo e do produto e a estratégia do controle centralizado) sugerem atenção especial das empresas para com esse elo, podendo até indicar como sendo estes também os motivos da integração vertical dele.

O elo do fabricante 3, os integrados, respondem perto de $10 \%$ de todo o custo da cadeia. A sua presença é estratégica na garantia da oferta do produto (aves para o abate), controle da produção, qualidade da carne, redução de custos (ativos imobilizados e de transação) e controle da rastreabilidade.

Apesar da indicação de que aparentemente o valor do custo para o fornecedor 3 não seja tão alto como o esperado, é importante salientar que diversos dos seus custos estão sob domínio do fabricante, como ajuda na construção das instalações, a matéria-prima (ração), o transporte, a negociação (quando existente), o aparato legal, dentre outros.

No mesmo âmbito, a presença de pequenos produtores, normalmente da agricultura familiar, também oferece uma certa flexibilidade pela sua localização pulverizada em torno dos abatedouros (elo fabricante), assim como redução nos custos de produção.

Uma vantagem significativa da coordenação vertical nesse elo é a nãonecessidade de investimentos em ativos imobilizados (terras) utilizados para a criação 
dos animais. O "aproveitamento" das terras possuídas por essas famílias retira a responsabilidade de altos investimentos dos fabricantes.

Tal ponto sugere uma redução dos custos do elo fabricante (os integradores). Mesmo assim, os investimentos apontados pela ABEF (2004) nessa relação podem ser justificados para a garantia do controle operacional.

Esse tipo de governança oferece uma certa flexibilidade de oferta, importante quando há variações significativas da demanda no mercado. Como prática, tais oscilações são absorvidas pelas variações de preços do frango e este tipo de sistema viabiliza a sua realização.

Os custos de transação também são reduzidos no processo da coordenação vertical, pois os custos de vendas, compras, administração de contratos e negociação são reduzidos. Os contratos são normalmente de longo prazo, exclusivos no fornecimento das aves, e não costumam se diferenciar de forma significativa entre eles.

Como os integrados são em grande quantidade, há uma economia em escala nesse sentido, indicando mais um fator positivo na viabilidade de tal tipo de governança na cadeia.

Todavia, mesmo com essa relativa baixa indicação de agregação de valor, o modelo de parceria (agroindústria - produtor rural) fundamenta-se como um dos fatores preponderantes da vantagem brasileira em relação a diversos países concorrentes. É o caso da Argentina, citado por Canever et al. (1997), e dos EUA, comentado por Rizzi (1993).

Portanto, o contato direto entre os dois elos é fundamental para o sucesso da cadeia e as iniciativas conjuntas de sinergia, de investimentos e de planejamento integrado atuam fortemente na constante melhoria desta estreita ligação.

À direita do fabricante, ou seja, o canal de distribuição, os dois elos não chegam a agregar um décimo de custo ao produto final. Esta conclusão vem da soma da participação normativa de agregação de custos do distribuidor e do varejista/consumidor final $(7,1 \%+2,7 \%=9,8 \%)$ 
Mesmo que esses valores também sejam baixos na cadeia toda, a importância dos canais de distribuição e da logística já foram bem sinalizadas ao longo do texto. O importante nesta parte da cadeia é salientar que a capilaridade dos canais de distribuição no mercado nacional, a necessidade de altos giros de estoques e as entregas rápidas são fundamentais para o negócio do frango.

A baixa margem no segmento do produto funcional indica que qualquer iniciativa que reduza os custos é sempre bem vista, até pelo tamanho do negócio, o que gera economia de escala.

Um exemplo realizado recentemente foi a melhora nas entregas para os compradores no Exterior. Normalmente, os carregamentos para exportação são pulverizados em pequenos lotes, mas para o maior número possível de destinos. A carga é despachada em navios frigorificados. Isto significa que a embarcação só é enviada quando atinge grandes volumes, para tornar o frete viável.

A iniciativa contempla o envio de carregamentos menores em substituição das grandes quantidades de cargas soltas nos navios, pelo uso de contêineres frigorificados. A medida possibilita reduzir custos, pois as entregas são mais rápidas, não necessitando a espera de acúmulo de carga antes da expedição. Portanto, a velocidade de entrega torna-se um diferencial competitivo para a cadeia do frango.

Esse ponto vai ao encontro do alinhamento estratégico responsivo indicado para os elos à frente do fabricante ao desenvolver atividades que focam na velocidade de resposta às demandas de mercado.

Dessa maneira, a primeira conclusão indicada na análise da divisão da agregação de custo pelos elos é que o mais importante nesse tipo de cadeia são as análises das relações existentes entre os mesmos. A sinergia existente permite ações conjuntas entre elos, não necessariamente concatenadas, com resultados que impactam a divisão de custos em toda a cadeia.

A discussão segue para os dados obtidos no preenchimento os custos agregados para cada área na Tabela 9. Analisando os dados da coluna de "Custos", 
percebe-se que os fluxos da área de produção são os mais importantes da cadeia, pois respondem por aproximadamente $70 \%$ dos custos totais. A Figura 22 mostra a divisão dos custos entre as áreas desenvolvidas no modelo.

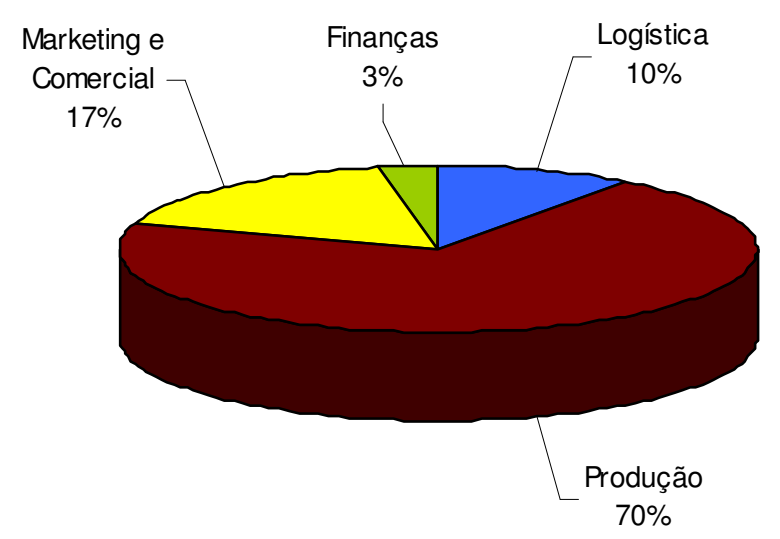

Figura 22 - Divisão dos custos entre as áreas da cadeia do frango

O fluxo de produtos, pertencente à área de produção, responde sozinho por quase metade de todo o custo da cadeia (45,5\%). O foco em sua otimização é fundamental e o mercado já se movimenta nesta direção, assim como nos desenvolvimentos e nos investimentos das principais empresas líderes.

Novamente, o exemplo para o caso é o planejamento integrado, que permite ajustar a produção dos frangos a níveis mais próximos da demanda de mercado. Esta iniciativa atua fortemente na relação entre os elos do fornecedor 3 e o fabricante. Entretanto, também há relações com os demais fornecedores, como é o caso do fornecedor 1, que produz alinhado com esta demanda.

Em seguida aparecem as áreas de marketing/comercial (17\%), de logística (10\%) e de finanças (3\%). O segundo fluxo mais importante é o de propriedade, cujo valor é de 8,5\% do custo total. Este é, também, passível de otimização matemática, nos mesmos moldes do planejamento integrado. 
Entretanto, é necessário estar sempre atento ao seu valor, uma vez que esse fluxo representa o capital de giro da empresa e, quanto menor, melhor. As iniciativas de redução de custos nos canais de distribuição e planejamento integrado são exemplos de trabalhos cujo impacto é direto na redução do capital de giro da cadeia.

Os demais fluxos, excluindo o de produtos e de propriedade, possuem divisão equilibrada, variando de $0,3 \%$ a 7,7\%. Esta análise pode ser feita usando-se a estatística descritiva. A Figura 23 representa graficamente a porcentagem individual que todos os fluxos agregam para a cadeia.

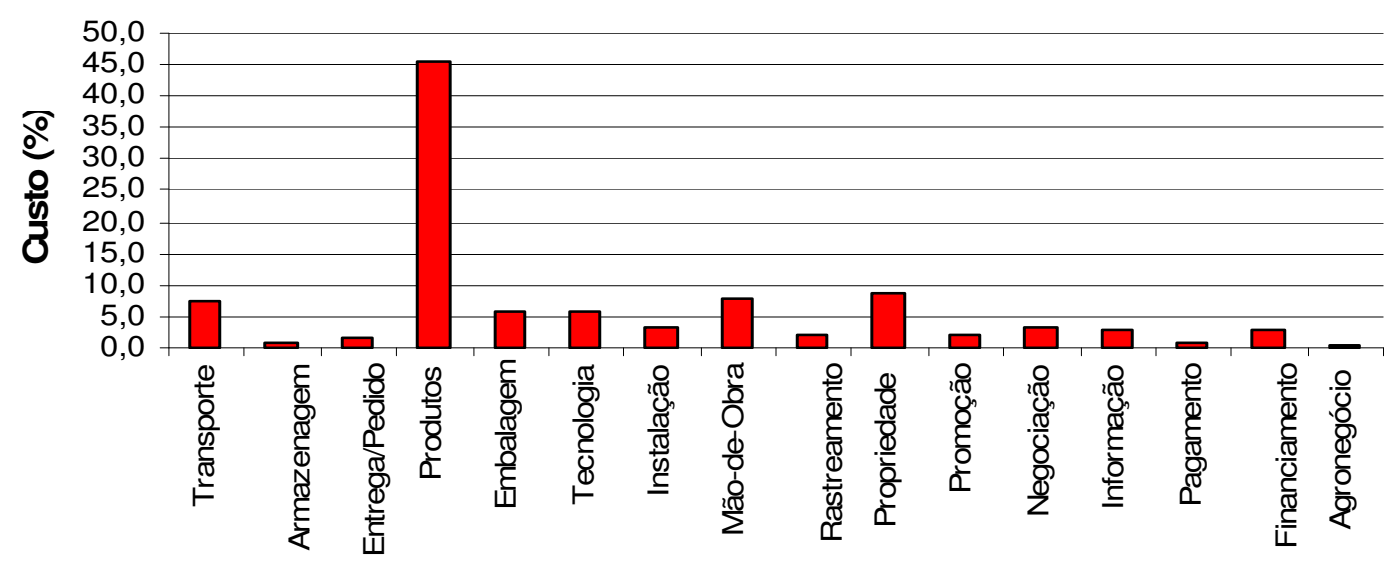

Fluxos

Figura 23 - Porcentagem de agregação de custos dos fluxos da cadeia de suprimentos

Esse mesmo raciocínio pode ser aplicado descontando o valor do fluxo de produtos. A intenção é verificar qual o resultado estatístico final, comparando ambos os cenários. A Tabela 10 compara os resultados.

Tabela 10. Comparação dos resultados estatísticos das duas análises para os fluxos

\begin{tabular}{lcc}
\hline & com todos os fluxos & sem o fluxo de produção \\
\hline Mediana & 2,90 & 2,70 \\
Média & 6,25 & 3,63 \\
Desvio-padrão & 10,78 & 2,69 \\
\hline
\end{tabular}


Os resultados dessa segunda análise mostram valores relativamente baixos, ao se comparar com o seu total de $100 \%$. A média de agregação de custo por fluxo é de $3,63 \%$, muito próximo de sua mediana (2,70\%). Apenas o desvio-padrão de 2,69\% acabou sendo relativamente alto se comparado com o valor da média; mesmo assim, a análise indicou pouca dispersão dos custos entre os fluxos adotados.

Os números indicam que o fluxo de produção deve ser o ponto-chave de preocupação na cadeia. Qualquer iniciativa isolada de redução de custos que atinja um único fluxo tende a ser menos representativa, mesmo com a economia de escala, se comparada com iniciativas mais amplas.

Ainda que haja indicação de alto potencial de agregação de valor, na última coluna da Tabela 9, o seu impacto isolado não deve ser percebido no desenvolvimento do negócio na cadeia.

Uma solução seria criar iniciativas conjuntas que atinjam um certo número de fluxos ao mesmo tempo, de preferência do maior número possível de áreas, aumentando a soma dos custos da cadeia a ser trabalhada. Outra solução é o constante investimento em melhorias na produção e otimização dos seus processos conjuntos.

Dessa maneira, os investimentos em melhorias na gestão da cadeia de suprimentos podem ser justificáveis se houver esforço em analisar a cadeia toda, com foco em diversas frentes de atuação, inclusive pelo impacto em diversas áreas e fluxos, em detrimento de esforços pontuais descasados da visão integrada.

Partindo-se para a analise da matriz D (Desempenho proporcional de fluxo dos elos da cadeia) entre os fluxos e os elos, começa-se a ter uma visão micro do gerenciamento da cadeia de suprimentos. A divisão dos dados agora será explorada sob a ótica dos participantes da cadeia, ou seja, os elos.

A importância da área de produção já foi sinalizada ao longo do texto. Acrescenta-se que tal área é apenas atuante na integração "para trás" (ou à jusante) da cadeia e o seu reflexo mais representativo está no fabricante. 
Quase metade de todo o custo da cadeia se concentra nessa área para o elo mencionado (41,0\%). Já o fornecedor 1 (responsável pelo fornecimento de toda a alimentação das aves) também merece destaque, uma vez que contribui com 18,5\% dos custos de produção da cadeia. Juntos, os dois elos somam aproximadamente $60 \%$ de todo o custo.

De certa forma, já era esperado que ambos tivessem alta importância para a cadeia, uma vez que um está diretamente relacionado ao outro, além de o fornecedor ser o elo que gerencia a cadeia integrada e esta análise já ter sido apontada anteriormente.

Qualquer iniciativa voltada aos fluxos de produção em ambos os elos pode envolver grandes quantidades financeiras, tanto de investimentos como de economias absolutas. Portanto, este ponto pode ajudar a justificar a preocupação com estratégias de alocação de recursos na busca pela otimização da produção ao longo de alguns elos da cadeia.

Vale destacar que a agregação de valor do fluxo de embalagens é de 5,6\% e está totalmente direcionada ao elo fabricante. Este ponto foi por diversas vezes discutido durante a realização do estudo de caso. Percebe-se que atualmente, devido às recentes altas do petróleo, o custo da embalagem de plástico está aumentando, o que reflete diretamente na cadeia e se torna ponto preocupante na análise. Qualquer variação, por menor que seja, impacta em grande escala nos custos.

Em seguida aparece o custo das áreas de marketing e comercial para o fabricante, com aproximadamente 5,3\%. É o quarto mais representativo da cadeia. Destaque para o fluxo de propriedade, que representa quase metade de todos os custos da área. Além disto, a maior parte do referido fluxo está concentrada nos três fornecedores $(75 \%)$, indicando que o canal de distribuição, aparentemente, possui alto giro de estoque.

Essa análise vem ao encontro do mercado de alimentos, cujos produtos têm prazos de validade curtos e enfrentam constantes variações de preços no mercado. Por ser uma cadeia cuja distribuição é caracterizada pela alta capilaridade e, numa breve 
análise, sem parâmetros de mercado ou de benchmarks, os $12 \%$ de todo capital de giro alocado no distribuidor revelam-se como um indicador bastante razoável.

A área de finanças é a que menos agrega custo à cadeia. Por ser de suporte na cadeia de valor, essa magnitude já era esperada e realmente deve sustentar a posição estratégica da cadeia de suprimentos. Entretanto, neste tipo de negócio e segundo os fluxos indicados, a área pouco agrega em termos de valor.

Disso não se exclui, em hipótese alguma, a sua importância. Pelo contrário, é dessa área que saem as informações necessárias para as tomadas de decisões. Mas o impacto delas é refletido nas demais áreas.

Mesmo assim, destaque para os fornecedores que agregam a maior parcela dos fluxos financeiros da cadeia e, principalmente, assumem grande parcela do risco de produção do agronegócio frango.

O destaque fica para os integrados (fornecedor 3) que são medidos pelo trabalho realizado na criação das aves. O fabricante lhe fornece todos os insumos necessários para a criação, mas o seu faturamento é resultado de critérios de desempenho e eficiência.

Portanto, os integrados assumem a maior parte do risco da criação, como indicado na tabela (35\%) e o fornecedor assume o risco de mercado. O fornecedor procura minimizar as perdas de produção ao exigir padrões mínimos de qualidade e infra-estrutura, além de fornecer pintos selecionados e rações balanceadas.

Para finalizar a análise dos resultados da Tabela 9, ao se analisar a coluna "Potencial de agregação de valor", a ponderação dos custos pode sugerir algumas análises interessantes. Seu uso é mais bem aplicado quando se analisa a agregação de valor entre os fluxos para um determinado segmento ou produto.

De uma forma simples, a análise dos conceitos relativamente recentes, muito discutidos atualmente no meio empresarial e acadêmico, mostraram alto potencial de agregação de valor. Citam-se, como exemplo, os fluxos de gestão de pedidos/entregas, 
tecnologia e informação. Salvo o fluxo de produtos, todos os demais estão com médio ou baixo potencial futuro de agregação de valor.

Diversas atividades estão próximas do que há de melhor no mercado ou estão em fase de melhoria constante, fato que pode ser verificado na ponderação do potencial de agregação de valor aos custos em "baixo". Destaque para o fluxo de transporte, que é significativo, mas tem menor potencial de agregação de valor na área de logística. Este mesmo raciocínio pode ser aplicado para o fluxo de mão-de-obra na produção.

Todas essas análises trazem diversos questionamentos em relação às áreas e aos fluxos. O primeiro plausível é a composição dos fluxos na composição da tabela. Diversos outros poderiam ser agregados, mas não estão. Neste caso, durante a condução do trabalho, muitos fluxos foram sinalizados, mas optou-se por alocar alguns destes sinalizados em outros já existentes para não tornar a análise da cadeia muito complexa.

Por exemplo, a questão da mão-de-obra na cadeia inteira poderia ter sido vista sob duas maneiras: acrescentar à tabela uma nova área de recursos humanos (RH), também de suporte, com um fluxo de mão-de-obra; ou em cada uma das quatro áreas estipuladas, de incluir um fluxo específico de mão-de-obra (como foi realizado apenas na área de produção, devido à sua importância).

Entretanto, ao se buscar todos os fluxos da cadeia de forma separada, a tabela ficará extremamente complexa e grande, podendo inviabilizar o raciocínio dos especialistas durante a busca pela divisão. A solução encontrada foi incorporar alguns fluxos não mencionados diretamente no estudo em outros fluxos mais abrangentes, utilizados no trabalho. Assim, elas foram contempladas.

O fluxo de transporte pode exemplificar esse ponto. Todas as atividades da cadeia de valor relacionadas ao assunto (como manutenção de veículos, mão-de-obra, combustível, manutenção etc.) foram contempladas neste fluxo. Assim, a visão de certa forma mais agregada possibilita a visualização de fluxos genéricos ao longo da análise, o que facilita o estudo. 
Outro questionamento sobre os fluxos seria a sua alocação nas áreas. Muito se discutiu sobre o fluxo de propriedade estar vinculado à área de marketing, uma vez que o controle e o gerenciamento de estoques é tradicionalmente da área de produção. Salienta-se que no caso do fluxo de propriedade, o que se analisa é o capital de giro e este ponto pode ser visto sob a ótica do marketing.

A gestão dos estoques é uma atividade que foi contemplada no fluxo marketing (propriedade). Mesmo assim, este ponto trouxe à tona a necessidade da realização de alguns cenários passíveis de comparação, o que será realizado adiante.

Por fim, confirma-se que a forma de análise utilizada não contempla os valores financeiros dos custos, mas a sua distribuição relativa ao longo de todos os elos da cadeia.

Isso significa que a análise não indicará as reduções ou aumentos absolutos de custos, se houver, resultado de otimizações, de planejamentos integrados e de melhorias gerenciais. Ela vai se ater apenas em responder como as mudanças refletem na divisão relativa dos novos custos ao longo da cadeia.

As ponderações também receberam críticas. No caso, o que ocorre se algumas delas forem invertidas? Diversos questionamentos do gênero foram feitos durante o trabalho e, posteriormente, durante as análises. Na seção seguinte, analisar-seão alguns cenários que incorporam e discutem os questionamentos levantados.

\subsection{Desenvolvimento de cenários}

O primeiro cenário a ser analisado é o da mudança de um fluxo da cadeia entre áreas que, porventura, possa ter causado polêmicas durante a formulação do modelo. Exemplificando: o fluxo de propriedade será realocado da área de marketing/comercial para a área de produção. A Tabela 11 mostra os resultados. 
Tabela 11. Cenário 1: rearranjo do fluxo de propriedade na cadeia de suprimentos

\begin{tabular}{|c|c|c|c|c|c|c|c|c|c|}
\hline & \multirow{3}{*}{ Custo $(\%)$} & \multicolumn{6}{|c|}{ Desempenho proporcional de fluxo dos elos da cadeia (\%) } & \multirow{3}{*}{$\begin{array}{l}\text { TOTAL } \\
(\%)\end{array}$} & \multirow{3}{*}{$\begin{array}{c}\text { Potencial de } \\
\text { agregação } \\
\text { de valor }\end{array}$} \\
\hline & & \multicolumn{3}{|c|}{ Fornecedores } & \multirow{2}{*}{ Fabricante } & \multirow{2}{*}{ Distribuidor } & \multirow{2}{*}{$\begin{array}{l}\text { Varejista/ } \\
\text { Consumidor } \\
\text { final }\end{array}$} & & \\
\hline & & 1 & 2 & 3 & & & & & \\
\hline Logística & 10,0 & 0,2 & 0,2 & 0,2 & 5,2 & 3,8 & 0,5 & 10,0 & \\
\hline Transporte & 7,5 & 2,0 & 2,0 & 2,0 & 56,0 & 38,0 & & 100,0 & $\mathrm{~B}$ \\
\hline Armazenagem & 1,0 & 5,0 & & & 12,0 & 36,0 & 47,0 & 100,0 & $M$ \\
\hline Entrega/Pedido & 1,5 & 1,0 & 1,0 & 1,0 & 57,0 & 40,0 & & 100,0 & $A$ \\
\hline Produção & 78,5 & 19,7 & 6,7 & 8,9 & 41,6 & 1,1 & 0,5 & 70,0 & \\
\hline Produtos & 45,5 & 35,0 & 5,0 & 10,0 & 50,0 & & & 100,0 & $A$ \\
\hline Propriedade & 8,5 & 15,0 & 30,0 & 30,0 & 8,0 & 12,0 & 5,0 & 100,0 & $M$ \\
\hline Embalagem & 5,6 & & & & 100,0 & & & 100,0 & $M$ \\
\hline Tecnologia & 5,6 & 20,0 & 15,0 & 15,0 & 50,0 & & & 100,0 & $A$ \\
\hline Instalação & 3,5 & 15,0 & 5,0 & & 80,0 & & & 100,0 & $M$ \\
\hline Mão-de-Obra & 7,7 & 6,0 & 3,0 & 1,0 & 90,0 & & & 100,0 & $\mathrm{~B}$ \\
\hline Rastreamento & 2,1 & 20,0 & 30,0 & 40,0 & 4,0 & 2,0 & 4,0 & 100,0 & $M$ \\
\hline Marketing e Comercial & 8,5 & 0,0 & 0,0 & 0,3 & 4,6 & 2,0 & 1,6 & 17,0 & \\
\hline Promoção & 2,0 & & & & 10,0 & 45,0 & 45,0 & 100,0 & $\mathrm{~B}$ \\
\hline Negociação & 3,1 & & & 10,0 & 70,0 & & 20,0 & 100,0 & B \\
\hline Informação & 2,7 & & & & 80,0 & 20,0 & & 100,0 & $A$ \\
\hline Pagamento & 0,7 & & & & 15,0 & 75,0 & 10,0 & 100,0 & $M$ \\
\hline Finanças & 3,0 & 0,9 & 0,3 & 0,9 & 0,4 & 0,3 & 0,2 & 3,0 & \\
\hline Financiamento & 2,7 & 30,0 & 10,0 & 30,0 & 14,0 & 10,0 & 6,0 & 100,0 & $M$ \\
\hline Agronegócio & 0,3 & 25,0 & 25,0 & 35,0 & 5,0 & 5,0 & 5,0 & 100,0 & $M$ \\
\hline $\begin{array}{l}\text { Participação normativa } \\
\text { na agregação de custos }\end{array}$ & - & $20,8 \%$ & $7,2 \%$ & $10,3 \%$ & $51,9 \%$ & $7,1 \%$ & $2,7 \%$ & $100,0 \%$ & - \\
\hline
\end{tabular}

Após a mudança desse fluxo para outra área, o que se verifica é a constância no principal resultado: a participação normativa na agregação de valor de todos os elos. Apenas como comprovação, estes valores realmente devem ser mantidos, independentemente do rearranjo entre os fluxos, pois se tratam de ponderações diretas entre os custos e os elos.

Entretanto, isso indica que as áreas são, na verdade, apenas mera agregação de fluxos, podendo ser refeitas a qualquer momento. A tabela receberia mudanças na divisão de custos em todos os elos e, por consequiência, na agregação de valor apenas se mais fluxos forem adicionados ou retirados e não realocados.

Todavia, houve mudanças nas participações das áreas na composição dos custos da cadeia. A área de produção passou de $70 \%$ para 78,5\%, um aumento de 8,5\% devido à realocação do fluxo de propriedade. Em contrapartida, este custo foi diminuído da área de marketing. 
A atenção deve estar sobre a distribuição do fluxo nas áreas, antes de tudo. Isto poderia trazer distorções se não fossem bem alocadas e o impacto de decisões na cadeia poderia não ser o esperado ao se utilizar este modelo.

Assim, a alocação dos fluxos em áreas fornece análises pontuais e de desempenho destas, podendo indicar a importância em termos de custos de cada uma delas na cadeia analisada.

O segundo cenário que se apresenta é a reformulação de alguns valores de agregação de custo, utilizando-se da ponderação da coluna "Potencial de agregação de valor". O intuito é verificar o grau do impacto destes potenciais na formação de uma nova coluna com novos valores dos custos e a conseqüência para o valor da participação normativa de cada elo na agregação de valor.

Supondo-se que para A (alto) o custo do fluxo tenha um decréscimo de um ponto percentual, $M$ (médio) o custo se mantenha e B (baixo) o custo tenha um acréscimo de um ponto percentual. A idéia é analisar o aumento da margem que um certo fluxo possa trazer quando este agrega valor maior ou menor que os demais, refletido no valor do produto final. Para tal, faz-se variar os custos, pois os dados de valor de cada fluxo não foram contemplados.

Para manter a coerência na tabela, quando é detectado um fluxo "A", existe a necessidade de uma contrapartida de um fluxo "B". A soma total dos custos deve ser sempre $100 \%$. A Tabela 12 contempla o que será analisado. 
Tabela 12. Cenário 2: ponderação dos custos pelo potencial de agregação de valor dos fluxos

\begin{tabular}{|c|c|c|c|c|c|c|c|c|c|}
\hline & \multirow{3}{*}{ Custo (\%) } & \multicolumn{6}{|c|}{ Desempenho proporcional de fluxo dos elos da cadeia (\%) } & \multirow{3}{*}{$\begin{array}{l}\text { TOTAL } \\
(\%)\end{array}$} & \multirow{3}{*}{$\begin{array}{c}\text { Potencial de } \\
\text { agregação } \\
\text { de valor }\end{array}$} \\
\hline & & \multicolumn{3}{|c|}{ Fornecedores } & \multirow{2}{*}{ Fabricante } & \multirow{2}{*}{ Distribuidor } & \multirow{2}{*}{$\begin{array}{c}\text { Varejista/ } \\
\text { Consumidor } \\
\text { final }\end{array}$} & & \\
\hline & & 1 & 2 & 3 & & & & & \\
\hline Logística & 10,0 & 0,2 & 0,2 & 0,2 & 5,2 & 3,8 & 0,5 & 10,0 & \\
\hline Transporte & 6,5 & 2,0 & 2,0 & 2,0 & 56,0 & 38,0 & & 100,0 & $\mathrm{~B}$ \\
\hline Armazenagem & 1,0 & 5,0 & & & 12,0 & 36,0 & 47,0 & 100,0 & M \\
\hline Entrega/Pedido & 2,5 & 1,0 & 1,0 & 1,0 & 57,0 & 40,0 & & 100,0 & A \\
\hline Produção & 71,0 & 18,9 & 4,3 & 6,5 & 41,1 & 0,0 & 0,1 & 71,0 & \\
\hline Produtos & 46,5 & 35,0 & 5,0 & 10,0 & 50,0 & & & 100,0 & $A$ \\
\hline Embalagem & 5,6 & & & & 100,0 & & & 100,0 & M \\
\hline Tecnologia & 6,6 & 20,0 & 15,0 & 15,0 & 50,0 & & & 100,0 & $A$ \\
\hline Instalação & 3,5 & 15,0 & 5,0 & & 80,0 & & & 100,0 & M \\
\hline Mão-de-Obra & 6,7 & 6,0 & 3,0 & 1,0 & 90,0 & & & 100,0 & $\mathrm{~B}$ \\
\hline Rastreamento & 2,1 & 20,0 & 30,0 & 40,0 & 4,0 & 2,0 & 4,0 & 100,0 & M \\
\hline Marketing e Comercial & 16,0 & 1,3 & 2,6 & 2,8 & 5,3 & 2,7 & 1,4 & 16,0 & \\
\hline Propriedade & 8,5 & 15,0 & 30,0 & 30,0 & 8,0 & 12,0 & 5,0 & 100,0 & $M$ \\
\hline Promoção & 1,0 & & & & 10,0 & 45,0 & 45,0 & 100,0 & B \\
\hline Negociação & 2,1 & & & 10,0 & 70,0 & & 20,0 & 100,0 & $B$ \\
\hline Informação & 3,7 & & & & 80,0 & 20,0 & & 100,0 & A \\
\hline Pagamento & 0,7 & & & & 15,0 & 75,0 & 10,0 & 100,0 & $\mathrm{M}$ \\
\hline Finanças & 3,0 & 0,9 & 0,3 & 0,9 & 0,4 & 0,3 & 0,2 & 3,0 & \\
\hline Financiamento & 2,7 & 30,0 & 10,0 & 30,0 & 14,0 & 10,0 & 6,0 & 100,0 & $M$ \\
\hline Agronegócio & 0,3 & 25,0 & 25,0 & 35,0 & 5,0 & 5,0 & 5,0 & 100,0 & M \\
\hline $\begin{array}{l}\text { Participação normativa } \\
\text { na agregação de custos }\end{array}$ & - & $21,3 \%$ & $7,4 \%$ & $10,5 \%$ & $52,1 \%$ & $6,9 \%$ & $2,1 \%$ & $100,0 \%$ & - \\
\hline
\end{tabular}

O que se percebe são pequenas mudanças na participação normativa de cada elo na agregação de custos. É um dos casos em que cada elo tem a sua agregação de custos modificada. Certamente, pois os dados dos custos dos fluxos foram modificados.

Todavia, as variações (de $-0,6 \%$ à $+0,5 \%$ ) não foram relevantes o suficiente. O varejista/consumidor final foi o que sofreu a maior baixa, com variação de $-0,6 \%$ do total. Já o fornecedor 1 teve a sua participação nos custos aumentada em $+0,5 \%$. Para os demais, as mudanças foram na caso dos $0,2 \%$, para cima ou para baixo. O impacto ocorreu diretamente na área de markting/comercial e, como era de se esperar, quase todos os fluxos diminuíram em função do aumento da área de produção.

Para ratificar a análise, propõe-se um terceiro cenário que contempla a inversão de todos os fluxos de produção para potencial alto de agregação de valor e a contrapartida em baixo dos demais para equivaler à divisão. 
A sugestão é verificar qual o impacto de uma otimização completa na área de produção ao sugerir que todos os seus fluxos podem agregar mais valor à cadeia, em detrimento dos fluxos das demais áreas.

A Tabela 13 esquematiza tais mudanças.

Tabela 13. Cenário 3: potencial de agregação de valor baixo para os fluxos de produção

\begin{tabular}{|c|c|c|c|c|c|c|c|c|c|}
\hline & \multirow{3}{*}{ Custo $(\%)$} & \multicolumn{6}{|c|}{ Desempenho proporcional de fluxo dos elos da cadeia (\%) } & \multirow{3}{*}{$\begin{array}{c}\text { TOTAL } \\
(\%)\end{array}$} & \multirow{3}{*}{$\begin{array}{c}\text { Potencial de } \\
\text { agregação } \\
\text { de valor }\end{array}$} \\
\hline & & \multicolumn{3}{|c|}{ Fornecedores } & \multirow{2}{*}{ Fabricante } & \multirow{2}{*}{ Distribuidor } & \multirow{2}{*}{$\begin{array}{l}\text { Varejista/ } \\
\text { Consumidor } \\
\text { final }\end{array}$} & & \\
\hline & & 1 & 2 & 3 & & & & & \\
\hline Logística & 12,0 & 0,2 & 0,2 & 0,2 & 6,3 & 4,6 & 0,5 & 12,0 & \\
\hline Transporte & 8,5 & 2,0 & 2,0 & 2,0 & 56,0 & 38,0 & & 100,0 & $\mathrm{~B}$ \\
\hline Armazenagem & 1,0 & 5,0 & & & 12,0 & 36,0 & 47,0 & 100,0 & $M$ \\
\hline Entrega/Pedido & 2,5 & 1,0 & 1,0 & 1,0 & 57,0 & 40,0 & & 100,0 & $B$ \\
\hline Produção & 64,0 & 17,5 & 3,6 & 5,6 & 37,2 & 0,0 & 0,0 & 64,0 & \\
\hline Produtos & 44,5 & 35,0 & 5,0 & 10,0 & 50,0 & & & 100,0 & $A$ \\
\hline Embalagem & 4,6 & & & & 100,0 & & & 100,0 & $A$ \\
\hline Tecnologia & 4,6 & 20,0 & 15,0 & 15,0 & 50,0 & & & 100,0 & $A$ \\
\hline Instalação & 2,5 & 15,0 & 5,0 & & 80,0 & & & 100,0 & $A$ \\
\hline Mão-de-Obra & 6,7 & 6,0 & 3,0 & 1,0 & 90,0 & & & 100,0 & $A$ \\
\hline Rastreamento & 1,1 & 20,0 & 30,0 & 40,0 & 4,0 & 2,0 & 4,0 & 100,0 & $A$ \\
\hline Marketing e Comercial & 21,0 & 1,3 & 2,6 & 3,0 & 7,1 & 4,4 & 2,8 & 21,0 & \\
\hline Propriedade & 8,5 & 15,0 & 30,0 & 30,0 & 8,0 & 12,0 & 5,0 & 100,0 & $M$ \\
\hline Promoção & 3,0 & & & & 10,0 & 45,0 & 45,0 & 100,0 & $\mathrm{~B}$ \\
\hline Negociação & 4,1 & & & 10,0 & 70,0 & & 20,0 & 100,0 & $\mathrm{~B}$ \\
\hline Informação & 3,7 & & & & 80,0 & 20,0 & & 100,0 & $\mathrm{~B}$ \\
\hline Pagamento & 1,7 & & & & 15,0 & 75,0 & 10,0 & 100,0 & $\mathrm{~B}$ \\
\hline Finanças & 3,0 & 0,9 & 0,3 & 0,9 & 0,4 & 0,3 & 0,2 & 3,0 & \\
\hline Financiamento & 2,7 & 30,0 & 10,0 & 30,0 & 14,0 & 10,0 & 6,0 & 100,0 & $M$ \\
\hline Agronegócio & 0,3 & 25,0 & 25,0 & 35,0 & 5,0 & 5,0 & 5,0 & 100,0 & $M$ \\
\hline $\begin{array}{l}\text { Participação normativa } \\
\text { na agregação de custos }\end{array}$ & - & $19,9 \%$ & $6,7 \%$ & $9,8 \%$ & $51,1 \%$ & $9,3 \%$ & $3,5 \%$ & $100,0 \%$ & - \\
\hline
\end{tabular}

Verifica-se que o mesmo raciocínio pode ser aplicado nesse cenário. Entretanto, se comparado com a Tabela 12, houve uma mudança nítida na participação de cada elo à jusante e à montante do fabricante. Todos os que se encontram à jusante do fabricante, inclusive este, sofreram queda. Em contrapartida, todos os elos à montante incrementaram as suas respectivas participações.

O maior impacto do aumento dos custos foi no distribuidor (de 7,1\% para 9,3\%). O terceiro cenário ponderou apenas a diminuição do potencial de agregação de 
valor nos fluxos da área de produção e conseqüente aumento dos fluxos das áreas de logística e de marketing/comercial.

O reflexo foi imediato no aumento da participação do distribuidor e do varejista/consumidor final nos custos totais, uma vez que as duas áreas que tiveram aumento do potencial de agregação possuem grande influência no canal de distribuição. Logicamente, todos os elos que basicamente agregam custos pela produção sofreram queda no seu percentual de contribuição de custos na cadeia.

Essa mudança é explicada pelo fato de a diminuição dos custos de produção que incidem quase totalmente nos elos produtores da cadeia. Por outro lado, a redução dos custos de produção da cadeia faz com que os demais elos contribuam com custos mais significativos em termos relativos. Isto não significa que ficaram mais custosos, apenas que as participações relativas ficaram mais altas.

Analisando os três cenários conjuntamente, a variação das participações normativas na agregação de valor foi relativamente baixa, conforme ilustrado na Tabela 14.

Tabela 14. Comparativo da participação normativa na agregação de valor para os três cenários

\begin{tabular}{lccccc}
\hline & \multicolumn{3}{c}{ Participação normativa na agregação de valor } & \\
\cline { 2 - 5 } & Estudo de caso & Cenário 1 & Cenário 2 & Cenário 3 & Variação \\
\hline Fornecedor 1 & $20,8 \%$ & $20,8 \%$ & $21,3 \%$ & $19,9 \%$ & $0,9 \%$ \\
Fornecedor 2 & $7,2 \%$ & $7,2 \%$ & $7,4 \%$ & $6,7 \%$ & $0,5 \%$ \\
Fornecedor 3 & $10,3 \%$ & $10,3 \%$ & $10,4 \%$ & $9,8 \%$ & $0,5 \%$ \\
Fabricante & $51,9 \%$ & $51,9 \%$ & $52,0 \%$ & $51,1 \%$ & $0,8 \%$ \\
Distribuidor & $7,1 \%$ & $7,1 \%$ & $6,9 \%$ & $9,3 \%$ & $2,2 \%$ \\
Varejista/ & $2,7 \%$ & $2,7 \%$ & $2,1 \%$ & $3,5 \%$ & $0,8 \%$ \\
Cons. Final & & & & & \\
\hline
\end{tabular}

Os valores da coluna "Variação" da Tabela 14 foram obtidos da diferença entre os valores do estudo de caso e o cenário mais representativo, tanto para cima 
quanto para baixo. Mesmo com as mudanças realizadas durante os cenários, pouca variação na agregação de custos foi percebida na cadeia.

A maior percebida $(2,2 \%)$ foi para o distribuidor no desenvolvimento do terceiro cenário. Em seguida, a segunda maior variação foi percebida para o fornecedor 1 durante o cenário três, com $0,9 \%$. O cenário três foi o que apresentou maior variação entre os elos.

As indicações dos três cenários sugerem duas preocupações principais quando da construção do modelo proposto: i) definição dos fluxos da cadeia estudada; ii) se houver necessidade de divisões em mais áreas, em quais os fluxos podem ser realocados; e iii) a análise de sensibilidade do impacto de decisões de redução de custos ao longo da cadeia.

As possíveis mudanças no modelo após a obtenção dos dados dos fluxos pelos elos são mais afetadas no sentido micro, ou seja, nas áreas. Impactos menores são percebidos na agregação de valor pelos elos que, se já bem estruturados, tendem a se manter. 


\section{CONCLUSÕES}

Uma importante evolução da economia de empresas e da administração toma força e está mudando de forma sutil e significativa o modo de se fazer negócios e de se relacionar, tanto dentro quanto fora dos limites empresariais.

Ainda que alguns países se encontrem nas fases iniciais da evolução da gestão da cadeia de suprimentos, os avanços são diretamente relacionados ao grau de avanço da economia local. A discrepância entre as economias mundiais ainda é um fator importante e o reflexo é direto nas empresas, mas o fato é que o caminho desta evolução está sendo global.

Muito do que se observa atualmente foi possibilitado pelo advento da tecnologia da informação. O uso do computador nos planejamentos complexos e avançados, no seqüenciamento de dados, nos cálculos avançados e na troca remota de informações, juntamente com a Internet, possibilitou o surgimento de um terreno propício para a evolução em gestão empresarial integrada.

Apenas o fato de todos os elos de uma cadeia de suprimentos compartilharem e utilizarem os mesmos dados para os seus dimensionamentos já é um ganho inestimável. Sendo tais ferramentas disponíveis para o desenvolvimento e o uso, o que se busca é a sustentabilidade das evoluções administrativas.

As ferramentas de tecnologia da informação se encontram num patamar bem mais avançado em termos de possibilidades (pela gama que oferecem) e potenciais (pela gama de soluções) que a real utilização prática. 
Mesmo assim, percebe-se que o desenvolvimento de atividades já realizadas pelas empresas, em quase todas as áreas, agora mais integradas do que nunca, resultam num trabalho conjunto que buscou no termo "gestão da cadeia de suprimentos" a designação do gerenciamento unificado.

Portanto, gestão da cadeia de suprimentos não se caracteriza como um novo conceito mas sim uma união de diversos conceitos de economia, administração, marketing e finanças, já fundamentados, e que se consolidam no sentido de trabalhar o “como" todos eles devem ser direcionados para almejar o mesmo objetivo.

Mais do que isso, os trabalhos passam dos limites gerenciais empresariais internos e atualmente se preocupam em desenvolver sinergias externas, todos sincronizados em um conjunto de organizações interdependentes. É um trabalho que já começou há algum tempo e que toma força num resultado inerente ao processo de evolução.

O reflexo desse cenário resgata a importância da integração dos elos na busca do lucro local e global. Como o objetivo de toda cadeia de suprimentos é a maximização do valor global gerado, toda análise da cadeia de valor torna fundamental a questão do posicionamento estratégico.

Aquela cadeia que consegue ter uma estrutura enxuta de custos está na vanguarda; portanto, é um fator relevante de sobrevivência presente nos dias atuais, sendo possível concluir que é uma necessidade primordial para um futuro não muito distante.

Alguns autores arriscam dizer que essa é a era da competição entre cadeias. Numa primeira análise, a empresa por si só deve ser lucrativa e sustentável no mercado onde atua, para posteriormente estar inserida em cadeias de suprimentos para que sejam competitivas e lucrativas.

Essas duas características são complementares. A primeira é a condição sine qua non de sobrevivência e a segunda é relevante no mesmo processo evolutivo, dando indícios de como serão os cenários a médio e longo prazos. 
Ainda assim, o lucro de cada organização deve ser visto sob a ótica sistemática da cadeia de suprimentos, para atuar de forma justa na equalização de divisão dos lucros, conseguindo otimizar o ganho total.

Ao se analisar o conjunto das empresas pertencentes a uma cadeia de suprimentos, a figura do gestor surge como ponto centralizador das tomadas de decisões e na sustentação do argumento de que ainda deve existir a figura centralizadora, organizadora e direcionadora de um líder, seja onde for.

A ECT traz os requisitos necessários que explicam o porquê da existência desse elo e como é a relação entre essas empresas ao tomar como base a análise dos contratos, além de preparar o cenário no qual se realizará o alinhamento estratégico da cadeia de suprimentos. O processo de tomada de decisão de qualquer estratégia empresarial terá reflexo direto nas cadeias de suprimentos onde a organização está inserida, seja ela a gestora ou não.

A busca pelo alinhamento estratégico entre todas essas organizações ou entre elos da cadeia é um ponto-chave de vantagem competitiva e sustentabilidade no mercado. Diversas são as organizações que assim o fizeram e tornaram-se referências tanto no meio empresarial quanto no meio acadêmico.

A adaptação desse alinhamento estratégico às necessidades de mercado, focando no que atualmente se comenta de agilidade (ou responsividade) e redução de custos (ou eficiência) é um paradigma que poucas cadeias conseguiram superar e gozam de consecutivos sucessos.

Conclui-se que tanto a agilidade como a eficiência devem caminhar conjuntamente em uma estratégia híbrida para a cadeia de suprimentos. Isto significa que parte dos elos pode ser gerenciada de forma eficiente e parte de forma responsiva. A sua total desvinculação mostra-se insustentável ao longo do tempo, sendo principalmente o fator custo o mais analisado e almejado.

Uma cadeia que consiga conciliar ambas as estratégias, possivelmente, terá um ganho a médio e longo prazos e será bem-sucedida. Esta conciliação é natural sob o 
ponto de vista da ECT para dar flexibilidade às eventualidades que o mercado consumidor pode trazer no curto prazo.

Assim, a integração vertical, a coordenação vertical, os contratos de parceria de curto prazo e as negociações com o mercado (spot) devem permear qualquer estratégia da cadeia, mesmo se houver supremacia de um modelo.

Via de regra, as operações passíveis de serem realizadas com economia de escala envolvem elos que devem ser priorizados na condução de cadeias eficientes, uma vez que o seu ganho é justificável pela economia de custos.

As funções, os fatores-chave e as atividades da cadeia de valor são dimensionados para tal fim. Neste caso, a integração vertical, os contratos de parceria ou a utilização do mercado priorizam a redução de custos.

Por outro lado, as operações (atividades) demandam agilidade para a cadeia favorecem o desenvolvimento de relacionamentos entre os elos em técnicas que priorizam a rapidez das operações (por exemplo, entregas, transportes e giro de estoques de produtos acabados) e o alto nível de serviço ao cliente. São, portanto, sensitivas ao mercado. Este relacionamento deve priorizar o serviço oferecido antes do custo envolvido, obviamente sem desmerecer em momento algum o custo.

As funções na cadeia de valor, os fatores-chave e as atividades devem se ajustar para contemplar esses requisitos. O desafio da adaptação desta conclusão para cada cadeia está no fato de dimensionar exatamente onde termina a estratégia da eficiência e onde começa a estratégia da responsividade, ou seja, o ponto de desacoplamento.

Internamente à empresa, todas as áreas são importantes e não deve haver supremacia de uma sobre a outra. A falta de uma delas quebra a união necessária para qualquer sobrevivência, mesmo que o avanço do território de cada uma delas, resultado do processo interno de evolução, traga conflitos. Logística, produção, marketing e finanças são as áreas mais atuantes em qualquer cadeia de suprimentos. 
Vale ressaltar que o detalhamento de outras áreas não incluídas no trabalho não deixa de ter a sua devida importância na agregação de valor da cadeia e da área em si. Apenas não foi necessário o seu desenvolvimento para o presente estudo. Os limites das responsabilidades passaram de departamentos para processos de negócios e a sua separação se torna menos difícil, embora mais voltada para a integração.

A cadeia de suprimentos integrada verticalmente já traz consigo um conceito de sinergia e integração fortemente almejado entre os elos de uma cadeia qualquer. A visualização de como esta cadeia é gerenciada pode fornecer a outras um modelo de sucesso em termos de gestão. Assim, garimpar cadeias de sucesso no meio empresarial para a sua análise em trabalhos acadêmicos é um forte direcionador neste tipo de pesquisa.

O que muitas cadeias procuram é atingir os benefícios da sinergia e as vantagens da estratégia verticalizada e tentar amenizar as desvantagens. Esta abordagem vem se desenvolvendo ao longo do tempo pelas práticas de cooperação e coordenação, podendo ser consideradas como evolução das práticas da integração vertical. Com isto, o advento do core business adquire cada vez mais espaço no cenário atual, tornando os elos das cadeias os mais especializados possível.

A terceirização de atividades-chave nos processos das cadeias também ajuda nesse processo, ao garantir que elas sejam praticadas e também consultadas no mercado assim que necessário. Portanto, a combinação de tarefas realizadas internamente (insourcing) com as realizadas externamente por terceiros, conhecidas como terceirização (outsoucing) são essenciais em qualquer cadeia hoje em dia.

As diversas formas de organização industrial existentes nos relacionamentos entre os elos de uma cadeia de suprimentos é discutida pela ECT e busca expor o que está por detrás de cada um deles.

A tomada de decisão na utilização do mercado, na adoção de contratos, nas parcerias e na integração vertical leva em consideração sempre aquele que minimiza os custos de transação. 
Esse resultado é inerente ao movimento econômico natural presente nas organizações e no cenário macroeconômico da cadeia, assim como discute o porquê de um elo específico ser o centralizador da cadeia.

A cadeia do frango no Brasil encontrou uma receita de sucesso para o gerenciamento integrado e, com isto, faz parte do rol de referências.

Percebe-se que a sinergia existente tem reflexo direto no desempenho operacional das empresas nacionais. Os crescentes avanços financeiros, econômicos e mercadológicos verificados nas últimas décadas demonstram isto.

Seu princípio está fundamentado na cadeia de suprimentos integrada e coordenada verticalmente, o que já traz consigo diversos benefícios para a gestão unificada.

$\mathrm{O}$ ponto central dessa cadeia se encontra no relacionamento entre os chamados "integrados" (fornecedor 3) com os "integradores" (fabricante). Com o uso do modelo de coordenação vertical, muito dos investimentos em ativos imobilizados para criação dos animais foram terceirizados para os integrados, já que estes possuem terras passíveis de utilização.

Assim, não houve necessidade de investimentos em terras por parte dos integradores (apesar de estes possuírem algumas), mas o controle de todas as suas atividades é garantido.

Os custos de transação também recebem economia de escala para esse relacionamento, pois os contratos firmados são normalmente de longo prazo, exclusivos no fornecimento das aves e não costumam se diferenciar de forma significativa entre eles.

A visualização de como os custos dessa cadeia estão distribuídos ao longo dos elos foi o foco deste estudo de caso, realizado segundo o desenho da cadeia de frango proposto, assim como a adaptação do modelo de eficiência do marketing para a cadeia de suprimentos. 
O desenvolvimento dos fluxos da cadeia de suprimentos, com base em fluxos dos canais de distribuição e na teoria da cadeia de valor, possibilitou o uso desta ferramenta em ambientes mais complexos.

A divisão holística de custos e de agregação de valor facilita a visualização da distribuição do desempenho de cada elo da cadeia o ponto de indicar onde há focos de melhorias. Entretanto, este modelo não se preocupa com a redução direta de custos financeiros, mas sim em verificar como eles estão divididos entre todos os participantes.

A indicação de que o elo "fabricante" é o mais custoso (aproximadamente $52 \%$ ) sugere que a principal importância em se focar as atividades de melhoria, otimizações e redução de custos terão impactos significativos em toda a cadeia de suprimentos e também na cadeia de valor.

Mais ainda, esse caso comprova o fato de que o elo centralizador traz para si diversos custos de toda a cadeia de suprimentos, o que reforça ainda mais a necessidade de priorizar investimentos neste elo e de se analisar como é a relação entre ele e os demais. Qualquer ganho nele se reflete tanto direta quanto indiretamente nos outros e, portanto, na cadeia.

O segundo elo mais importante foi indicado como sendo o "fornecedor 1", com aproximadamente $21 \%$ dos custos da cadeia. O alto valor dos custos, o uso de ativos específicos (ração desenvolvida com exclusividade) e a frequiência das transações deste elo com o fabricante sugerem a sua integração vertical.

Mesmo com custos menores se comparado com os demais elos, o fornecedor 2 também acompanha essas características. Ademais, o desenvolvimento das aves para a cadeia é estratégico, o que também indica a sua integração.

No caso do alinhamento estratégico, a cadeia do frango sugere um ponto de separação, onde ela pode ser gerenciada de forma híbrida nos dois tipos sugeridos: responsivo e eficiente.

Com o custo em torno de $90 \%$ de toda a cadeia distribuído à jusante do fabricante, incluindo o próprio, o alinhamento estratégico na eficiência pode ser aplicado 
em todos os elos. Mais do que isto, o distribuidor deve também entrar na análise, principalmente por ser o responsável pelos CDs da cadeia.

Os ganhos em escala são justificáveis para a busca de redução de custos em planejamentos integrados, otimizações na utilização de materiais (como capital de giro, matérias-primas e maquinários) ou de processos (abates e industrialização). Os direcionamentos podem ser obtidos pela gestão integrada de planejamentos advindos das previsões de demanda do mercado.

Os demais elos à montante podem ser alinhados de forma responsiva na busca do ótimo do nível de serviço (entregas na quantidade certa no período combinado). Esta agilidade pode fornecer à cadeia um diferencial de resposta rápida às mudanças de curto prazo no mercado, além de garantir a venda pela capilaridade já existente nos canais de distribuição.

O conjunto dessas duas estratégias se fundamenta naquilo que grande parte das cadeias de suprimentos almejam, que é a sustentabilidade de cadeias enxutas em termos de custos conciliada com um eficaz sistema de resposta rápida no atendimento do nível de serviço estrategicamente estipulado, ou seja, o alinhamento estratégico híbrido bem fundamentado.

No todo, a prática gerencial de colaboração sempre foi buscada. Tomou maior importância porque o crescimento foi mais rápido que a evolução industrial. Mesmo que todo tipo de colaboração traga riscos, o melhor modelo deve ser analisado sob a ótica da estratégia de gestão da cadeia de suprimentos e das transações necessárias.

Todas essas observações sugerem a necessidade de um profissional muito bem capacitado para atuar no ambiente empresarial. A busca por esta pessoa poderá ser bem-sucedida se o candidato possuir uma visão holística do macro e do microambiente. Se houver necessidade, vale a pena a realização de investimentos em treinamentos e capacitações específicas para o desempenho das ações na área onde for atuar.

Para tanto, há dois caminhos a seguir: o primeiro envolvendo o aproveitamento de profissionais já existentes nas empresas, que poderão receber 
treinamento para desenvolver conceitos de integração empresarial, ou em outras palavras, em gestão da cadeia de suprimentos. Uma vez que já possuem conhecimentos da área e das atividades que desenvolvem no seu dia-a-dia, o passo seguinte é desenvolver a visão holística.

Já o segundo caminho fará mais sentido quando surgir a necessidade de contratação de novos profissionais. Eles poderão ser escolhidos pelos seus conhecimentos já adquiridos sob visão holística e sobre gestão da cadeia de suprimentos. A sua adequação para realizar as tarefas ocorrerá por meio de investimentos que possibilitarão o conhecimento e o desempenho sobre o que será requisitado.

Portanto, o desenvolvimento das habilidades prioriza o que se necessitará operacionalmente, mas já se sabendo que esse profissional possui a visão integrada da empresa e das cadeias na qual ela está inserida, além dos possíveis trade-offs de qualquer movimento estratégico.

\subsection{Limitações e recomendações de trabalhos futuros}

A metodologia aplicada em marketing mostrou-se bem fundamentada para o estudo de caso realizado. Ela pode ser melhorada e até adaptada em diversos tipos de cadeias, sendo esta uma primeira recomendação de trabalho.

Há de se considerar que o presente estudo de caso foi realizado em duas instituições: uma associação da área e uma empresa representante do elo fabricante da cadeia do frango, o que pode levantar a hipótese de os dados carregarem vieses deste elo da cadeia, o que não deixa de ser uma restrição do estudo.

Todavia, é necessário ter em mente que o elo fabricante foi indicado como sendo o gestor da cadeia. Seria o único elo capaz de fornecer as informações de todos os demais, segundo uma visão holística do negócio.

A melhor situação é realizar entrevistas em todos os elos da cadeia a fim de se averiguar discrepâncias de dados, assim como a visão completa descentralizada, 
capaz de reduzir os possíveis vieses. Quanto maior o número de entrevistados ou especialistas, sempre melhor se torna a análise.

Por outro lado, o uso dessa metodologia em cadeias não integradas verticalmente pode ser dificultado durante a busca das informações e das rodadas necessárias. Dependendo de onde se aplicar, resultados distintos poderão ser obtidos, inclusive para este mesmo estudo de caso.

Fica assim registrada a segunda sugestão de um trabalho de pesquisa que possa acrescentar dados e se aprofundar em outros tipos de análises para o ambiente tratado nesta dissertação.

Outra restrição do modelo foi a decisão de agrupamento dos elos dos canais de distribuição em um único (varejista/consumidor final). Originalmente, o modelo de eficiência foi desenvolvido para aplicação em canais de distribuição. No estudo de caso realizado, chegou-se num acordo de não detalhar os elos dos canais, pois eles não mais pertenciam ao domínio integrado verticalmente do fabricante na cadeia do frango.

A não-agregação desses elos indicava dificuldades na busca de dados e em entrevistas, o que poderia inviabilizar a pesquisa tanto em tempo quanto no que se pretendia com o modelo.

Como o modelo proposto foi aplicado e validado, é sugerido um possível terceiro trabalho de pesquisa: o detalhamento da cadeia em elos à montante do fabricante e a possível entrevista com todos os seus representantes a fim de enriquecer a tabela com dados mais desagregados.

Toda a análise foi realizada para o "negócio frango", não havendo preocupação em diferenciar por produto, por segmento de mercado ou por canal de distribuição.

Esse ponto indica um quarto trabalho, com foco num produto específico. Por exemplo, os nuggets de frango possuem valor agregado maior e seu preço no mercado é mais alto se comparado ao frango inteiro. 
O desenvolvimento do trabalho nesse sentido pode ser focado não com olhos em custos, mas na agregação de valor de cada elo na cadeia de suprimentos. Tal estudo contemplará mais ainda as divisões do princípio da equiidade, pois sugere a divisão pela agregação de valor ao produto final.

Para cada uma das sugestões, aconselha-se a verificação prévia de possibilidade da busca dos dados, pois é considerado o principal desafio do trabalho. A pesquisa pode se tornar inviável se o planejamento e as entrevistas não forem bem detalhadas e se não houver a garantia das entrevistas antes do início das atividades.

Em relação ao modelo proposto, o principal ponto a ser detalhado está relacionado à identificação dos fluxos (atividades da cadeia de valor) que devem existir e, se houver necessidade, das áreas a serem trabalhadas.

A forma de agregação dos dados a ser definida previamente, vai determinar essas diferenças. Ainda assim, a aplicação dessa metodologia com o resgate de dados pela técnica do $\mathrm{ABC}$ também será um grande desafio do pesquisador ou do gestor da empresa.

Os fluxos da cadeia de suprimentos estão com alto grau de agrupamento, necessário para a condução do estudo e validação da metodologia. O seu detalhamento poderia dificultar a análise dos especialistas durante a busca pelos dados e, com isto, agregar pouco valor ao estudo, uma outra restrição do modelo aplicado. Mesmo assim, os fluxos podem ser mais discriminados para especificar as análises nas áreas e a tabela contemplar diversos outros aspectos no modelo apresentado. Esta é a quinta sugestão de pesquisa

Mesmo com a indicação do potencial de agregação de valor dos fluxos da cadeia de suprimentos, há espaço para o seu detalhamento em termos de grau nessa agregação. Cada um dos elos pode ser quebrado em macroprocessos de negócios e analisados sob a ótica de quais realmente agregam valor para a cadeia.

Esses tópicos sugerem estudos correlatos. Realizar trabalhos envolvendo apenas uma área, mas que detalhem os seus fluxos a ponto de serem aprofundados e 
analisados exclusivamente sob a ótica dos custos de transação trará diversas contribuições para as organizações, indicação esta da sexta sugestão de pesquisa.

O dimensionamento quantitativo da redução de custos de transação pela coordenação vertical entre os elos do fornecedor 3 e o fabricante é a sétima sugestão de pesquisa complementar ao presente trabalho.

Outra linha de estudo possível é o detalhamento dos relacionamentos existentes entre os elos. Foram encontrados diversos trabalhos neste sentido, inclusive para a cadeia do frango, citados ao longo do texto. Entretanto, ainda faltam estudos que contemplem principalmente os relacionamentos à montante da cadeia, oitava sugestão de pesquisa.

A sugestão do alinhamento das estratégias da cadeia de suprimentos em responsiva e eficiente merece detalhamentos de como isso pode ser alcançado em outras cadeias, principalmente as não integradas verticalmente.

Destaque-se que diversos outros cenários e cadeias podem receber análise semelhante. Os benefícios da integração vertical serão sempre almejados por todas as cadeias. Esta metodologia poderá indicar bons caminhos nas tomadas de decisões sob futuras formas de governança nas cadeias de suprimentos. 


\section{REFERÊNCIAS BIBLIOGRÁFICAS}

ASSOCIAÇÃO BRASILEIRA DE LOGÍSTICA (ASLOG). Conferências. http://www.aslog.org.br (13 fev. 2004)

ASSOCIAÇÃO BRASILEIRA DOS PRODUTORES E EXPORTADORES DE FRANGO (ABEF). Relatório anual 2003. São Paulo, 2004. 21p.

AVESEOVOS. Mercado de frango. http://www.aveseovos.com.br (10 jul. 2004)

AZEVEDO, P.F.; BANKUTI, F.I. Na clandestinidade: o mercado informal da carne bovina. http://www.iea.sp.gov.br (27 abr. 2004)

BALLOU, R.H. Gerenciamento da cadeia de suprimentos: planejamento, organização e logística empresarial. 4.ed. Porto Alegre: Boodkman, 2001. 532p.

BERTAGLiA, P.R. Logística e gerenciamento da cadeia de abastecimento. São Paulo: Saraiva, 2003. 509p.

BESANKO, D.; DRANOVE, D.; SHANLEY, M. Economics of strategy. 2.ed. Chichester: John Wiley \& Sons, 2000. 644p.

BIANCHINI, V.K.; ALVES, M.R.P.A. Transaction cost economics applied to the management of the supply chain: a case study of the relationship between mills and the food industry. In: CONGRESSO INTERNACIONAL DE ECONOMIA E GESTÃO DE REDES AGROALIMENTARES, 4., Ribeirão Preto, 2003. Anais. Ribeirão Preto: FEARP, 2003. 13p. 
BOND, E. Medição de desempenho para gestão da produção em um cenário de cadeia de suprimentos. São Carlos, 2002. 125p. Dissertação (Mestrado) - Escola de Engenharia de São Carlos, Universidade de São Paulo.

BOWERSOX, D.J.; CLOSS, D.J. Logística empresarial: o processo de integração da cadeia de suprimento. São Paulo: Atlas, 2001. 594p.

CANEVER, M.D.; TALAMINI, D.J.D.; CAMPOS, A.C.; SANTOS FILHO, J.I. dos. A cadeia produtiva do frango de corte no Brasil e na Argentina. Concórdia: EMBRAPA, CNPSA, 1997. 150p.

CHOPRA, S.; MEINDL, P. Gerenciamento da cadeia de suprimentos. São Paulo: Prentice Hall, 2003. 465p.

CHRISTOPHER, M. Logistics and supply chain management. London: Financial Times Publishing, 1998. 68p.

CHRISTOPHER, M. The agile supply chain: competing in volatile markets. Industrial Marketing Management, v.29, n.1, p.37-44, 2000.

COASE, R.H. The nature of the firm. Economica, v.4, n.1, p.386-405, Nov. 1937.

CONSOLI, M.A.; NEVES, M.F.; LOPES, F.F. Costs of marketing channels flows: a food business case applying the channel efficiency model. In: EUROPEAN MARKETING ACADEMY CONFERENCE - EMAC, 33: Wordwide Marketing. Proceedings. Murcia: Universidade de Murcia, 2004.

COUGHLAN, A.T.; ANDERSON, E.; STERN, L.W.; EL-ANSARAY, A.I. Canais de marketing e distribuição. 6.ed. Porto Alegre: Bookman, 2002. 461p.

COX III, J.F.; BLACKSTONE JUNIOR, J.H. APICS Dictionary. 9.ed. Falls Church: American Production and Inventory Control Society, 1998. 104p.

DASKIN, M.S. Logistics: an overview of the state of the art and perspectives on future research. Transportation Research, v.19A, n.5/6, p.383-393, 1985.

DELOITTE CONSULTING. Energizando o supply chain: tendências e desafios do supply chain management no Brasil (compact disc). São Paulo, 2002. 
DÖR, A.C. O posicionamento da indústria avícola frente às restrições do mercado comum europeu. Piracicaba, 2003. 145p. Dissertação (Mestrado) - Escola Superior de Agricultura “Luiz de Queiroz”, Universidade de São Paulo.

DYER, J.H.; KALE, P.; SINGH, H. When to ally, when to acquire: top-line growth. Harvard Business Review, p.109-115, July/Aug. 2004. Special supplement.

FAVARET-FILHO, P.; PAULA, S.R.L. de. Cadeia da carne bovina: o novo ambiente competitivo. BNDES Setorial, n.6, p.1-17, set. 1997.

FAVARET-FILHO, P.; PAULA, S.R.L. de. Um estudo da integração a partir do projeto Buriti, da Perdigão. BNDES Setorial, n.7, p.123-134, mar. 1998.

FIGUEIREDO, K.F.; FLEURY, P.F.; WANKE, P. (Org.). Logística e gerenciamento da cadeia de suprimentos: planejamento do fluxo de produtos e dos recursos. São Paulo: Atlas, 2003. 483p.

FISHER, M.L. What is the right supply chain for your product? Harvard Business Review, v.2, n.75, p.83-93, Mar./Apr. 1997.

GADDE, L.; HÅKANSSON, H. Supply network strategies. Chichester: John Wiley \& Sons, 2001. 206p.

GRANT, R.M. Contemporary strategy analysis. 4.ed. Cambridge: Blackwell, 2002. $551 \mathrm{p}$.

GREEN, R.; SCHALLER, B. Logística e racionalização comercial na área dos produtos alimentares frescos. In: BELIK, W.; MALUF, R.S. (Org.). Abastecimento e segurança alimentar, os limites da liberalização. Campinas: Universidade Estadual de Campinas, Instituto de Economia, 2000. p.107-130.

HANASHIRO, M.M. Relações de coordenação entre agricultura, indústria e distribuição na cadeia produtiva dos produtos minimamente processados. Campinas, 2003. 125p. Dissertação (Mestrado) - Instituto de Economia, Universidade Estadual de Campinas. 
JANK, M.S. Competitividade do agribusiness brasileiro: discussão teórica e evidências no sistema carnes. São Paulo, 1996. 195p. Tese (Doutorado) - Faculdade de Economia Administração e Contabilidade, Universidade de São Paulo.

LAMBERT, D.M.; COOPER, M.C.; PAGH, J.D. Supply chain management: implementation, issues and research opportunities. The International Journal of Logistics Management, v.9, n.2, p.1-19, 1998.

LIDERANÇA em pedaços. Globo Rural, v.19, n.224, p.49-51, jun. 2004.

MARQUES, P.V. Economia da integração vertical na avicultura de corte do Estado de São Paulo. Piracicaba, 1991. 130p. Tese (Livre-Docência) - Escola Superior de Agricultura "Luiz de Queiroz", Universidade de São Paulo.

MUSETTI, M.A. A identificação da entidade gestora logística: uma contribuição para seu processo de formação e educação. São Carlos, 2000. 168p. Tese (Doutorado) Escola de Engenharia de São Carlos, Universidade de São Paulo.

NEVES, M.F. Um modelo para planejamento de canais de distribuição no setor de alimentos. São Paulo, 1999. 297p. Tese (Doutorado) - Faculdade de Economia, Administração e Contabilidade, Universidade de São Paulo.

NEVES, M.F; CHADDAD, F.R.; LAZZARINI, S.G. Alimentos: novos tempos e conceitos na gestão de negócios. São Paulo: Pioneira, 2000. 129p.

NOGUEIRA, A.C.L.; ZYLBERSZTAJN, D. Coexistence of institutional arrangements in slaughter aviculture in the state of São Paulo. In: CONGRESSO INTERNACIONAL DE ECONOMIA E GESTÃO DE REDES AGROALIMENTARES, 4., Ribeirão Preto, 2003. Anais. Ribeirão Preto: FEARP, 2003. 14p.

NORTH, D. Custos de transação, instituições de desempenho econômico. Rio de Janeiro: Instituto Liberal, 1994. 152p.

PIRES, S.R.I. Gestão da cadeia de suprimentos e o modelo de consórcio modular. Revista de Administração, v.33, n.3, p.5-15, 1998. 
PIRES, S.R.I.; BREMER, C.; SANTA EULÁLIA, L.; GOULART, C. Supply chain and virtual enterprises: comparisons, migration and a case study. International Journal of Logistics Research and Applications, v.4, n.3, p.32-44, 2001.

PIRES, S.R.I. Gestão da cadeia de suprimentos (supply chain management): conceitos, estratégias, práticas e casos. São Paulo: Atlas, 2004. 310p.

PORTER, M.E. Vantagem competitiva: criando e sustentando um desempenho superior. 16.ed. Rio de Janeiro: Campus, 1989. 512p.

PORTER, M.E. Estratégia competitiva: técnicas para a análise de indústrias e da concorrência. 7.ed. Rio de Janeiro: Campus, 1997. 376p.

RIZZI, A.T. Mudanças tecnológicas e reestruturação da indústria agroalimentar: o caso da indústria de frangos no Brasil. Campinas, 1993. 194p. Tese (Doutorado) Instituto de Economia, Universidade Estadual de Campinas.

RUSSEL, S.H. Growing world of logistics. Air Force Journal of Logistics, v.24, n.4, p.10-14, 1998.

SABOYA, L.V. A dinâmica locacional da avicultura e suinocultura no centro-oeste brasileiro. Piracicaba, 2001. 166p. Dissertação (Mestrado) - Escola de Agricultura “Luiz de Queiroz”, Universidade de São Paulo.

SANTA EULALIA, L.A. Uma contribuição para a formalização do processo de gestão da demanda no âmbito do planejamento e controle de produção em empresas MTS (make to stock). São Carlos, 2001. 231p. Dissertação (Mestrado) - Escola de Engenharia de São Carlos, Universidade de São Paulo.

SILVA, C.A.V. da; MUSETTI, M.A. Logísticas militar e empresarial: uma abordagem reflexiva. Revista de Administração, v.38, n.4, p.343-354, out./nov./dez. 2003.

SOUZA, J.P.; PEREIRA, L.B.; SANTANA, E.A. Estratégias competitivas da cadeia agroindustrial de carnes no Brasil: percepções do distribuidor. http//www.fanorpi.com.br/web/exercicios2003/EstratégiasCompetitivas20Carnes.pd f. (25 mar. 2004) 
STERN, L.W.; EL-ANSARY, A.I.; COUGHLAN, A. Marketing channels. 5.ed. São Paulo: Prentice Hall, 1996. 576p.

TAUBE-NETTO, M. Integrated planning for poultry production at Sadia. Interfaces, v.26, n.1, p.38-53, Jan./Feb. 1996.

UNIÃO BRASILEIRA DE AVICULTURA (UBA). Relatório anual 2003/2004. Brasília, 2003. 70p.

WILliAMSON, O.E. The economics institutions of capitalism: firms, markets, relational contracting. New York: The Free Press, 1985. 450p.

WOMACK, J.; JONES, D.; ROSS, D. A máquina que mudou o mundo. São Paulo: Campus, 2004. 342p.

WRIGHT, J.T.C.; GIOVINAZZO, R.A. Delphi: uma ferramenta de apoio ao planejamento prospectivo. Caderno de Pesquisas em Administração, v.1, n.12, p.54-65, 2000.

YIN, R.Y. Estudo de caso: planejamento e métodos. 2.ed. São Paulo: Bookman, 2001. $205 p$.

ZIMMERMAN, J.L.; SMITH, C.W.; BRICKEY, J.A. Managerial economics and organizational architecture. Cambridge: McGraw-Hill/Irwin, 1997. 458p.

ZYLBERSZTAJN, D. Estruturas de governança e coordenação do agribusiness: uma aplicação da Nova Economia das Instituições. São Paulo, 1995. 237p. Tese (LivreDocência) - Faculdade de Economia, Administração e Contabilidade, Universidade de São Paulo. 